Econometrics Working Paper EWP9901

ISSN 1485-6441

\title{
Export-led Growth : A Survey of the Empirical Literature and Some Noncausality Results ${ }^{1}$
}

\author{
Judith A. Giles and Cara L.Williams \\ University of Victoria
}

First version, May 1998: This version, January 1999

\begin{abstract}
The economic development and growth literature contains extensive discussions on relationships between exports and economic growth. One debate centers on whether countries should promote the export sector to obtain economic growth. An abundant empirical literature on this export-led growth (ELG) hypothesis has followed. We contribute to this literature in two ways. First, we provide a comprehensive survey of more than one hundred and fifty export-growth applied papers. We describe the changes that have occurred, over the last two decades, in the methodologies used to empirically examine for relationships between exports and economic growth, and we provide information on the current findings. The last decade has seen an abundance of time series studies which focus on examining for causality via exclusions restrictions tests, impulse response function analysis and forecast error variance decompositions. Our second contribution is to examine some of these time series methods. We show that ELG results based on standard causality techniques are not typically robust to specification or method. We do this by reconsidering two export-led growth applications - Oxley 1993 study for Portugal and Henriques and Sadorsky 1996 analysis for Canada. Our results suggest that extreme care should be exercised when interpreting much of the applied research on the ELG hypothesis.
\end{abstract}

JEL CLASSIFICATIONS: F43, O11, 051, 052

KEYWORDS: economic growth, export promotion, causality, time series models, robustness, misspecification, model dimension, cointegration, innovation accounting.

${ }^{1}$ Correspondence to: Judith A. Giles, Department of Economics, University of Victoria, PO Box 1700, Victoria, B.C., Canada, V8W 2Y2. Email: jgiles@uvic.ca; telephone: 250-721-8542. We are grateful to Les Oxley and Irene Henriques for providing us with their data sets, and to David Giles and other seminar participants at the University of Victoria, Deakin University and the Reserve Bank of New Zealand for helpful comments. An earlier version of this paper was presented at the 1998 Canadian Economics Association Meeting. This research was supported by a grant from the Social Sciences and Humanities Research Council of Canada for the first author. 


\section{Introduction}

The notion that export activity leads economic growth has been subject to considerable debate in the development and growth literature for many decades (for example, Mrydal, 1970; Little et al., 1970; Meier, 1984; Keesing, 1967; Bhagwati and Srinivasan, 1978; Krueger, 1978, 1980, $1985)^{2}$. Is export growth the Angine@f economic growth, is it only a Anandmaiden@or is there only a contemporaneous relationship between them? (Nurkse, 1961; Kravis, 1970). This literature is part of a larger one, which relates the trade regime/outward orientation and growth, and a literature that dates back to the nineteenth century ${ }^{3}$. For the export-led growth (ELG) studies outward orientation is measured by some function of the trade flow of exports. We limit our attention to this body of work and we ignore, for practicality reasons alone, those studies which use alternative definitions of trade or Apenness@

Broadly, the focus of the ELG debate is on whether a country is better served by orienting trade policies to export promotion or to import substitution ${ }^{4}$. The neoclassical view has been that growth can be achieved by export-led growth (ELG): the growth records of Asian newly industrializing countries (NICs) - in particular, Hong Kong, Singapore, Korea and Taiwan, secondgeneration NICs (Malaysia and Thailand) - are cited as such examples (compared to, say, Latin America and Africa). Over the last thirty years these NICs have approximately doubled their standards of living every ten years. China is the latest country to join this group: AChina experience during the 1980s and 1990s tend[s] to support the argument that openness to trade is a mechanism for achieving more rapid and efficient growth and better distribution of domestic resources@Findlay and Watson, 1996, p.4). Many studies contain similar assertions for other countries and some authors (e.g., Krueger, 1995; Sachs and Warner, 1995) identify trade policy as the crucial element of economic policy. The World Bank (1993) perceives the experiences of these countries as a mnodel= for development: a view supported by the US Agency for International Development and the International Monetary Fund.

The effectiveness of export promotion is in the end an empirical issue: over the last twenty years or so there has been a plethora of such investigations, using a number of statistical techniques. Overall, it is difficult to decide for or against ELG as many studies show conflicting results. Our first aim in this paper is to provide a summary of the empirical literature, and we present information on more than one hundred and fifty papers. We concentrate on papers that are explicitly interested in

2

See Bhagwati (1986) for a survey and critique of this literature.

See Södersten (1964), Haring (1963) and Balassa (1989) for discussions of some of the early contributions to the growth/trade debate.

Some authors distinguish between a strategy of ELG and one of export promotion (e.g., Bhagwati, 1986, 1988b;

Barnham et al., 1992). The former is one which gives primary emphasis to exports as opposed to production for the domestic market. Export promotion, on the other hand, is defined as a development strategy of eliminating biases against exports (for instance, removing quotas); it may include incentives to foster exports but production for the domestic market may also be encouraged. We recognize the validity of such a separation but it is a distinction that may be difficult to separate at the broad macro level we are studying empirically. Consequently, we do not distinguish between ELG and export promotion. 
the export-economic growth relationship rather than those which may be interested in explaining growth per se. We also exclude applied research involved in the endogenous/exogenous growth literature. Jung and Marshall (1985), Greenaway and Sapsford (1994a,b), Riezman et al. (1996), Dhananjayan and Devi (1997) and Shan and Sun (1998b) also provide surveys on the applied ELG work. The 1985 study is naturally dated while the later papers are quite narrow: Greenaway and Sapsford provide information on thirteen papers, Riezman et al. discuss sixteen investigations, Dhananjayan and Devi review fourteen studies while the survey of Shan and Sun is longer but still only considers thirty papers. Edwards (1993) also contains a discussion on a few of the early applications. The empirical literature separates into three: the first studies use cross-country correlation coefficients to test the ELG hypothesis; these were followed by regression applications (typically least squares based) which were again usually cross-country predicated; the third, recent group of works, apply various time series techniques to examine the exports-growth nexus. Potential problems with the cross-country methods are well documented in the literature and some problems with the later time series studies are also noted. Our second aim is to discuss a number of other concerns regarding the time series studies, which we illustrate employing data for Portugal as studied by Oxley (1993) and for Canada as analyzed by Henriques and Sadorsky (1996).

This paper is organized as follows. In the following section we briefly outline the possible relationships which may exist between exports and economic growth, and we describe and summarize our survey of the empirical literature to date in section 3. Further, section 3 presents discussions of the current time series techniques. Our illustrations of the conflicts that may result with the data from Portugal and Canada are given in section 4. The final section provides a summary, some suggestions for applied researchers, and our concluding remarks.

\section{Export-led growth; growth-led exports or feedback?}

There are a number of reasons within trade theory to support the export-led growth proposition (see, for instance, Krugman, 1987; Havyrlyshyn, 1990 for a survey). First, export growth may represent an increase in demand for the country output and thus serves to increase real output. Second, an expansion in exports may promote specialization in the production of export products, which in turn may boost the productivity level and may cause the general level of skills to rise in the export sector. This may then lead to a reallocation of resources from the (relatively) inefficient nontrade sector to the higher productive export sector. The productivity change may lead to output growth. This effect is sometimes called $\forall$ erdoorn $₹$ Law $=$ after P.J. Verdoorn who suggested it in 1949. The outward oriented trade policy may also give access to advanced technologies, learning by doing gains, and better management practices (e.g., Caves, 1970; Hart, 1983; Krugman, 1987; Ben-David and Loewy, 1996; Lucas, 1988; Rivera-Batiz and Romer, 1993; Romer, 1990) which may result in further efficiency gains. Third, an increase in exports may loosen a foreign exchange constraint (see, for instance, McKinnon, 1964; Chenery and Strout, 1966; Esfahani, 1991) which makes it easier to import inputs to meet domestic demand and so allow for output expansion. Outward orientation makes it possible to use external capital for development and so not suffering from a debt servicing problem and, it is argued, export promotion may eliminate controls that result in an overvaluation of the domestic currency.

Export development of certain goods based upon a country comparative advantage may allow the exploitation of economies of scale that may lead to increased growth. This argument 
proposes that domestic markets are too small for optimal scale to be achieved while increasing returns may occur with access to foreign markets. Additionally, export-led growth may be seen as part of the product and industry life-cycle hypothesis (e.g., Cornwall, 1977; Yarborough and Yarborough, 1994). This hypothesis describes economic growth as a cycle that begins with exports of primary goods. Over time, economic growth and knowledge change the structure of the domestic economy, including consumer demand, which propels the more technology intensive domestic industry to begin exporting: as domestic demand ebbs, economic growth arises from technologically advanced exports. Finally, some propose (e.g., Lal and Rajapatirana, 1987) that an outward-oriented strategy of development may provide greater opportunities and rewards for entrepreneurial activity which, it is argued, is the key to extended growth as it is the entrepreneur who will seek out risk and opportunity.

The support for export-led growth is not universal. Critics point out that the experiences in the East and Southeast Asian countries are unique in many ways and not necessarily replicable in other countries. The dynamic general equilibrium model of a small open LDC developed by Buffie (1992) is supportive of this idea. He determines that whether an export boom acts as an engine of growth depends on the structural characteristics of the economy. Others question whether a reliance on exports to lead the economy will result in sustained long-term economic growth in the less developed countries due to the volatility and unpredictability in the world market (e.g., Jaffee, 1985). Another issue is whether the markets in developed countries are large enough for exports from further less developed countries (LDCs), or whether trade barriers will impede this route of development ${ }^{5}$. Some scholars support the counter development strategy of protectionism or import substitution (e.g., Prebisch, 1950, 1959; Singer, 1950. See also Bagchi, 1982; Prebisch, 1984; Bruton, 1989; Grabowski, 1994). This involves utilizing a variety of policy instruments (tariffs, quotas and subsidies) to substitute domestic output for imports; import substitution can be implemented without impacts from other economies and the benefits to increased employment and output are immediate. Such government policies can be used to foster domestic firms rather than foreign ones: e.g., Brander and Spencer, (1985). See Krugman (1989) and Brander (1995) for surveys. Based on the experience of Latin American countries, in particular, it is argued that trade between the ANorth@and the ASouth@ has been detrimental to some Latin American countries, resulting in high government expenditure on incentive schemes, ecological damage, trade imbalances and setbacks to domestic industry and agriculture (e.g., Hamilton and Thompson, 1994). Part of this may be due to the type of good that is being traded (see also Eswaran and Kotwal, 1993). ${ }^{6}$ Promotion of import substitution industries may also help to develop a variety of industries while export promotion may only result in a select number of industries and may lead to a country being stuck producing goods from which the economic gains have been exhausted (e.g., Young, 1991). Some argue (e.g., Corden, 1987) that financing development via import substitution may be politically attractive as tariffs, quotas, etc., may raise taxes in a hidden fashion. Grossman and Helpman (1991) show that use of tariffs may benefit countries with a comparative disadvantage in key sectors (R\&D for instance) and lead to greater growth. Advocates of selective import protection also prevail (e.g., Taylor, 1988) and empirically

$5 \quad$ See, for example, Adelman (1984) and Cline (1984) and the references therein.

This suggests that it may be important to dis-aggregate total real exports by commodity group. This is rarely undertaken in empirical work. Some exceptions are Giles et al. (1992) for New Zealand, Findlay and Watson (1996) for China, Boltho (1996) for Japan and Tuan and Ng (1998) for Hong Kong. 
many countries promote exports in one or more sectors while protecting others. Export promotion and import substitution strategies may well be complementary, the latter may be a necessary step for export-based growth; e.g., Grabowski (1994) and Hamilton and Thompson (1994).

There is also potential for growth-led exports (GLE). Bhagwati (1988a) postulates that GLE is likely, unless antitrade bias results from the growth-induced supply and demand. Neoclassical trade theory supports this (e.g., Findlay, 1984) positing that other factors aside from exports are responsible for output growth (e.g., primary input growth and/or factor productivity growth). A growth-led exports (GLE) orthodoxy is justified by, for instance, Kaldor (1964), Lancaster (1980), Krugman (1984) and Stavrinos (1987): economic growth leads to enhancement of skills and technology with this increased efficiency creating a comparative advantage for the country which facilitates exports. Market failure, with subsequent government intervention, may also result in GLE.

A feedback relationship between exports and output is an interesting prospect. For example, Helpman and Krugman (1985) postulate that exports may rise from the realization of economies of scale due to productivity gains; the rise in exports may further enable cost reductions which may result in further productivity gains. Bhagwati (1988a) conjectures that increased trade (irrespective of cause) produces more income, and more income leads to more trade and so on. See also Cornwall (1977) and Grossman and Helpman (1991).

There is finally potential for no causal relationship between exports and economic growth: the growth paths of the two time series are determined by other, unrelated variables in the economic system (e.g., Pack, 1988, 1992; Yaghmaian, 1994).

\section{The empirical literature}

The empirical approaches to the ELG debate have taken three forms. Details are given in Tables A1 and A2: Table A1 lists the cross-sectional investigations between 1963 and 1998 while Table A2 provides information on the literature between 1972 and 1998 that consider individual country analyses over time. One group of cross-section research looks at rank correlation coefficients or simple OLS regressions between exports and output (Maizels, 1963, 1968; Haring and Humphrey, 1964; Syron and Walsh , 1968; Kravis, 1970; Voivodas, 1973; Michaely, 1977; Balassa, 1978a,b, 1982; Heller and Porter, 1978; Tyler, 1981; Kavoussi, 1984, 1985; Rana, 1986; Gonçlaves and Richtering, 1987; Singer and Gray, 1988; Greenaway and Sapsford, 1994b). The number of countries dealt with varies from seven to more than one hundred; various time periods are investigated and several definitions of the Axport@and Aconomic growth@variable are adopted. The export-led growth hypothesis is supported if a positive, significant correlation is observed. The general conclusion from these simple cross-sectional correlation studies is that high levels of economic growth are significantly associated with high levels of export growth. One issue arising from this body of work is that some of the results may involve a spurious correlation due to exports themselves being part of national product. This Accounting identity@ffect leads some authors to use output net of exports or alternative export variables. Also arising from this research is that there may be a need for a minimum threshold of development before any association may exist. That is, export-led growth may only arise after a certain level of development (usually proxied by income) has been achieved.

As only exports and growth are investigated, any observed correlation may be reflective of underlying relationships via other economic variables. This concern results in a group of crosssectional studies which estimate aggregate production functions that include exports as an 
explanatory variable along with other proposed economic growth determining fundamentals such as labor, capital, investment and so on: Emery, 1967; Michalopoulos and Jay, 1973; Papanek, 1973; Voivodas, 1973; Williamson, 1978; Balassa, 1978a, 1981, 1984, 1985; Tyler, 1981; Feder, 1983; Salvatore, 1983; Kavoussi, 1984; Kormendi and Meguire, 1985; Jaffee, 1985; Ram, 1985; Helliener, 1986; Rana, 1986, 1988; Kohli and Singh, 1989; Mbaku, 1989; Moschos, 1989; Fosu, 1990a, 1996; Otani and Villaneuva, 1990; Sheehey, 1990, 1992; Dodaro, 1991; Esfahani, 1991; Salvatore and Hatcher, 1991; Sawhney and DiPietro, 1991; Dollar, 1992; De Gregorio, 1992; Moore, 1992; Sprout and Weaver, 1993; Coppin, 1994; Greenaway and Sapsford, 1994b; Hotchkiss et al., 1994; Amirkhalkhali and Dar, 1995; Song and Chen, 1995; Yaghmaian and Ghorashi, 1995; Burney, 1996; Park and Prime, 1997; McNab and Moore, 1998.

Linear regression models are estimated in which a growth variable is regressed on an export variable. The export growth hypothesis is supported if the coefficient on the export variable is significantly positive. The growth variable is typically real GDP but in some studies is per capita GDP or manufacturing output or non-export GDP aiming to overcome the Accounting identity@roblem. Likewise, various definitions of exports are applied including growth in real exports, manufacturing or merchandise exports, export share of GDP, \% share of changes in exports in GDP. Some consider the differential impacts of exports on economic growth depending on the level of economic/industrial development of the country: the so-called critical minimum effort hypothesis. A popular approach is based on Feder (1983) model of export-growth linkages in which the growth rate of labor and capital inputs enter as explanatory variables for the growth of GNP as well as the growth rate of exports, though this approach has been subject to criticism as it assumes no diminishing returns to an increasing export share and it also imposes that the relative efficiency is the same for export and non-export production, irrespective of the size of the domestic markets. These empirical studies have supported the notions that developing countries with favorable export growth have experienced higher rates of growth of national output over a wide range of countries and time periods.

Exceptions include Papanek (1973), Kormendi and Meguire (1985), Helleiner (1986), Gonçlaves and Richtering (1987), Mbaku (1989), De Gregorio (1992), Sprout and Weaver (1993), Greenaway and Sapsford (1994b), Amirkhalkhali and Dar (1995), Yaghmaian and Ghorashi (1995), Burney (1996). It is difficult to isolate why these investigations do not support export promotion while other studies do though different country sets, time periods and variable definitions are three obvious reasons. For example, Gonçlaves and Richtering find a significant positive export/economic growth effect when growth is measured via total GDP but not for non-export GDP - this may well be a reflection of the Accounting identity@issue raised earlier; Sprout and Weaver (1993) and Amirkhalkhali and Dar (1995) determine that the groupings of countries matter; Greenaway and Sapsford (1994b), Yaghmaian and Ghorashi (1995) and Burney (1996) illustrate that ELG changes with time periods. Papanek (1973), Kormendi and Meguire (1985) and De Gregorio (1992) include explanatory variables not analyzed elsewhere, raising whether the export/economic growth effect observed in other studies is spurious reflecting third variable effects. Sheehey (1990) observes positive correlations for other production categories; e.g., agriculture, manufacturing, construction, services. Since it is common to all or most other sectors it would seem that the framework may be flawed at detecting whether promotion of one sector can lead to overall economic growth.

Several authors suggest that endogeneity issues have not been adequately dealt with, though re-estimation of models using a simultaneous equations estimation principle does not typically change the outcome. Further, it is typically recognized that these studies fail to distinguish between statistical 
association and statistical causation ${ }^{7}$. Effectively, these studies take positive associations as evidence of causation. The cross-country regressions provide little insight into the way the various right-hand side variables affect growth and the dynamic behaviors within countries; given the possible simultaneity involved in such models the positive association is as compatible with growth-led exports as with ELG or feedback effects. Further, both output and exports could be causal with another set of unspecified variables. That reverse causation or feedback is not allowed for can lead to inconsistent decision rules.

In addition, these models have typically implicitly assumed that the regression parameters are constant across countries ${ }^{8}$; that is, production functions and the degree of factor differentiation between factor productivities in different sectors are assumed everywhere the same. Such studies do not allow for differences between countries in their institutional, political, financial structures and in their reactions to external shocks that may be important even when the samples chosen consider countries which according to some criteria (e.g., income) may appear homogeneous. Many of the cross-country studies also use averaged growth rates which may introduce mis-specifications and parameter instabilities (see, for example, McDonald and Roberts, 1996) as the averages ignore changes which have occurred overtime for the same country.

The recognition of these described potential difficulties with this cross-sectional research in attempting to examine for export-led growth has led to the third group of studies which have reconsidered the ELG hypothesis by testing for causality in a formal way. Three time series methods are common, some more so than others: formal exclusion restrictions' hypothesis tests, generation of impulse response functions (IRFs), and forecast error variance decompositions (FEVDs) ${ }^{9}$. These properties are linked. Table A2 details the time series studies. Prior to comparing the results we first provide some necessary theoretical considerations on testing for causality. In this preliminary discussion we present some summary information from Table A2 and we employ example countries to illustrate some of the comments. We discuss the empirical research further in section 3.2.

\subsection{Theoretical considerations}

The most prevalent causality approach is grounded in Granger $(1963,1969)$ work, which builds on earlier research by Weiner (1956): the notion is one of predictability being synonymous with causality, and is based on the idea that a cause cannot come after an effect. Of the studies in Table A2, 74\% use some from of Granger causality to test for ELG; the other $26 \%$ use time series data to estimate regression models which do not incorporate dynamic effects. Granger's approach is Atheoretical@n the sense that no attempt is made to incorporate economic theory to impose any a

\footnotetext{
The cross-country researchers often recognize this. For example, Ram (1985) notes that At is evidently important to be able to make a reasonably satisfactory transition from statements about the correlation patterns to some judgements about the causal structure@p.416).

8 This shortcoming was often noted. See, among others, Helleiner (1986), Feder (1983) and the references therein. Some authors estimate random coefficient models (e.g., Amirkhalkhali and Dar, 1995) while others (e.g., De Gregorio, 1992) estimate random effects panel models as ways to overcome this criticism.

9 Also called innovation accounting.
} 
priori restrictions upon the relationships between the variables of interest to the researcher. We say that $\mathrm{y}$ causes $\mathrm{x}$ if all available past information allows us to predict $\mathrm{x}$ better than we can when all past information except y is used. More formally, let $\Omega_{\mathrm{t}}$ be the information set containing all relevant information available up to and including the time period ${ }^{10} \mathrm{t}$; let $\mathrm{x}_{\mathrm{t}}\left(1 \mid \Omega_{\mathrm{t}}\right.$ ) be the optimal (minimum mean squared error (MSE)) 1-step predictor of $x_{t}$ at time $t$, based on the information in $\Omega_{t}$; let $\mathrm{M}_{\mathrm{x}}\left(1 \mid \Omega_{\mathrm{t}}\right)$ denote the resulting 1-step forecast MSE. Then, $\mathrm{y}_{\mathrm{t}}$ is said to Granger-cause $\mathrm{x}_{\mathrm{t}}$ one-period ahead if, in the matrix sense, $\mathrm{M}_{\mathrm{x}}\left(1 \mid \Omega_{\mathrm{t}}\right)<\mathrm{M}_{\mathrm{x}}\left(1 \mid \Omega_{\mathrm{t}}\right.$ excl. $\left.\left\{\mathrm{y}_{\mathrm{t}} \mid \mathrm{s} \leq \mathrm{t}\right\}\right)$, where $\Omega_{\mathrm{t}}$ excl. $\left\{\mathrm{y}_{\mathrm{t}} \mid \mathrm{s} \leq \mathrm{t}\right\}$ is the set containing all relevant information except that pertaining to the past and present of $y_{t}$. There are many critics of this concept; this is not surprising as Apredict@is not akin to Aforce,@which is philosophically more parallel to Aause.@Zellner (1979) for instance, argues against it on admissibility grounds; it is not practical to have all information at hand and so no globally optimal predictor is feasibly available. Consequently, implementation is usually undertaken by using the information in the past and present of the variables under study; $\Omega_{\mathrm{t}}$ is replaced by $\left\{\mathrm{x}_{\mathrm{s}}, \mathrm{y}_{\mathrm{s}} \mid \mathrm{s} \leq \mathrm{t}\right\}$. Further, attention typically focuses on the (potentially) restrictive class of optimal linear predictors. Nevertheless, Granger concept of causality is popular in an empirical world that searches for means to statistically ascertain directions of causality and the strength of any such relationships.

In order to define the links between causality testing, IRFs and FEVDs we suppose initially that a $\mathrm{K}$-dimensional stable ${ }^{11}$ process $\mathrm{Z}_{\mathrm{t}}$ possesses a moving average representation of the form:

$$
\mathrm{z}_{\mathrm{t}}=\mu+\sum_{\mathrm{i}=0}^{\infty} \phi_{\mathrm{i}} \mathrm{u}_{\mathrm{t}-\mathrm{i}}=\mu+\phi(\mathrm{L}) \mathrm{u}_{\mathrm{t}}, \phi_{0}=\mathrm{I}_{\mathrm{K}}
$$

where $\phi_{i}, i \geq 0$, are $K \times K$ absolutely summable matrices, $\phi(L)=\sum_{i=0}^{\infty} \phi_{i} L^{i}$ is a matrix in the lag operator $\mathrm{L}, \mathrm{u}_{\mathrm{t}}$ is a white noise process with nonsingular covariance matrix $\Sigma_{\mathrm{u}}{ }^{12}$. Suppose $\mathrm{z}_{\mathrm{t}}$ is partitioned as $\mathrm{z}_{\mathrm{t}}=\left(\mathrm{x}_{\mathrm{t}}{ }^{\prime}, \mathrm{y}_{\mathrm{t}}{ }^{\prime}\right)^{\prime}$, where $\mathrm{x}_{\mathrm{t}}$ has dimension $\mathrm{K}_{1}, \mathrm{y}_{\mathrm{t}}$ has dimension $\mathrm{K}_{2}$ and $\mathrm{K}_{1}+\mathrm{K}_{2}=\mathrm{K}$. Note that all variables in the system are involved in the causality under study: this is important. Partitioning the MA representation accordingly we write (1) as:

$$
\mathrm{z}_{\mathrm{t}}=\left[\begin{array}{l}
\mathrm{x}_{\mathrm{t}} \\
\mathrm{y}_{\mathrm{t}}
\end{array}\right]=\left[\begin{array}{l}
\mu_{1} \\
\mu_{2}
\end{array}\right]+\left[\begin{array}{ll}
\phi_{11}(\mathrm{~L}) & \phi_{12}(\mathrm{~L}) \\
\phi_{21}(\mathrm{~L}) & \phi_{22}(\mathrm{~L})
\end{array}\right]\left[\begin{array}{l}
\mathrm{u}_{1 \mathrm{t}} \\
\mathrm{u}_{2 \mathrm{t}}
\end{array}\right]
$$

from which it follows that for forecasting $x_{t} 1$-step ahead $y_{t}$ Granger non-causes $x_{t}$ if $\phi_{12, i}=0$ for $i=$ $1,2, \ldots$. We write this as 1-step $y_{t} \nrightarrow x_{t}$. Note that 1-step $y_{t} \nrightarrow x_{t}$, given the information set, is

See, for example, Lütkepohl (1993a) for further details and discussion. We spend the time here defining causality more rigorously than usual in applied studies as it enables weaknesses of the idea to be quite obvious and it makes a comparison between systems of different dimensions more straightforward.

11 Stability implies stationarity. This assumption can be relaxed for the setup of the models; the difficulty then is in the asymptotic distributions of the relevant test statistics. It is in dealing with possible non-stationarity issues that causes a number of the differences in the results of the empirical literature on ELG. We will return to this issue. 
equivalent to 1-step $\mathrm{y}_{\mathrm{jt}} \nrightarrow \mathrm{x}_{\mathrm{t}}, \mathrm{j}=1, \ldots, \mathrm{K}_{2} ; 1$-step $\mathrm{y}_{\mathrm{t}} \nrightarrow \mathrm{x}_{\mathrm{it}}, \mathrm{i}=1, \ldots, \mathrm{K}_{1}$; and 1 -step $\mathrm{y}_{\mathrm{jt}} \nrightarrow \mathrm{x}_{\mathrm{it}}, \mathrm{j}=1, \ldots, \mathrm{K}_{2}$ and $\mathrm{i}=1, \ldots, \mathrm{K}_{1}$ : Dufour and Renault (1998) Proposition 2.1 .

The MA representation leads directly to the IRFs and FEVDs: concepts pioneered by Sims $(1980,1981,1982)$. Suppose we desire the response of $x_{t}$ (or one of its elements) to an impulse from $\mathrm{y}_{\mathrm{t}}$ (or one of its components); that is, we wish to describe the time path on $\mathrm{x}_{\mathrm{t}}$ from a shock or innovation in $\mathrm{y}_{\mathrm{t}}$. This is the IRF and, in the setup we have described, is given by the MA components; see, Lütkepohl (1993a , pp.43-56). Then the impulse responses are zero if one of the variables does not Granger-cause the other variables taken as a group. For example, in a bivariate system consisting of export growth and GDP growth the IRF function from an innovation in export growth will consist of zero effects if there is no ELG in the Granger sense. Conversely, to continue this example, significant non-zero impulse responses suggest Granger-causality, in the system we are currently describing.

One problem with this treatment is that it follows from an innovation in only one variable which may be unrealistic as variables in the system are unlikely to be independent so that shocks in one variable are likely to cause shocks in other variables due to error term correlations. Consequently, most IRFs are generated by appropriately orthogonalizing to give uncorrelated errors. Unfortunately, no unique decomposition is possible and ordering of the variables matters. This may limit a linking between IRFs and Granger-causality in practice.

FEVDs also arise from the MA representation of the system. We suppose that the error terms in (1) or (2) are uncorrelated, or that the system has been appropriately orthogonalized. The h-step forecast MSE for the $\mathrm{j}$ variable in $\mathrm{z}_{\mathrm{t}}$ is given by: $\operatorname{MSE}\left(\mathrm{z}_{\mathrm{j}, \mathrm{t}}(\mathrm{h})\right)=\sum_{\mathrm{i}=0}^{\mathrm{h}-1} \sum_{\mathrm{k}=1}^{\mathrm{K}} \phi_{\mathrm{jk}, \mathrm{i}}^{2}=\sum_{\mathrm{k}=1}^{\mathrm{K}} \omega_{\mathrm{jk}, \mathrm{h}}$ where $\phi_{\mathrm{jk}, \mathrm{i}}$ is the $\mathrm{jk}^{\text {th }}$ element of $\phi_{\mathrm{i}}$ and $\omega_{\mathrm{jk}, \mathrm{h}} / \mathrm{MSE}\left(\mathrm{z}_{\mathrm{j}, \mathrm{t}}(\mathrm{h})\right)$ is the proportion of the h-step forecast error variance of variable $\mathrm{j}$ accounted for by innovations in variable $\mathrm{k}$ : the so called FEVDs. In a system consisting of two variables (or vectors) $\mathrm{y}_{\mathrm{t}}$ and $\mathrm{x}_{\mathrm{t}}$, Granger-noncausality implies that the FEVD of $\mathrm{y}_{\mathrm{t}}$, for instance, accounted for by the innovations of $\mathrm{x}_{\mathrm{t}}$ must be zero. Conversely, in such a system, a significant nonzero FEVD implies causality in the Granger sense; see Sims (1972) and Pierce and Haugh (1977). However, orthogonalizing the error terms may result in non-zero FEVDs even if there is noncausality in the Granger sense; this will depend on the instantaneous causation in the system (see Lütkepohl, 1993a, p58).

Assuming that $z_{t}$ is invertible, we can rewrite (1) and (2) as a vector autoregressive (VAR) model, which could be of order infinity, but for our purposes we assume is of finite order p:

$$
\mathrm{Zt}_{\mathrm{t}}=\left[\begin{array}{l}
\mathrm{x}_{\mathrm{t}} \\
\mathrm{y}_{\mathrm{t}}
\end{array}\right]=\left[\begin{array}{l}
\mathrm{v}_{1} \\
\mathrm{v}_{2}
\end{array}\right]+\sum_{\mathrm{i}=1}^{\mathrm{p}}\left[\begin{array}{ll}
\theta_{11, \mathrm{i}} & \theta_{12, \mathrm{i}} \\
\theta_{21, \mathrm{i}} & \theta_{22, \mathrm{i}}
\end{array}\right]\left[\begin{array}{l}
\mathrm{x}_{\mathrm{t}-\mathrm{i}} \\
\mathrm{y}_{\mathrm{t}-\mathrm{i}}
\end{array}\right]+\left[\begin{array}{l}
\mathrm{u}_{1 \mathrm{t}} \\
\mathrm{u}_{2 \mathrm{t}}
\end{array}\right]
$$

from which 1-step $y_{t} \not \rightarrow x_{t}$ follows if $\theta_{12, i}=0$ for $i=1,2, \ldots$. Examining the validity of these exclusion restrictions, using LR, Wald and F-tests, is the typical method adopted to test for Granger noncausality ${ }^{13}$. Many of the studies in Table A2 examine for causality within bivariate and higher order systems; allowing for this, 57\% undertake bivariate analyses and of these all but one examine

13

The use of VARs themselves is controversial. Several scholars criticize their lack of foundation in theory and that they are data-driven in many ways. See, for example, Leamer (1985) and Cooley and Le Roy (1985). 
for causality via restrictions tests on the AR representation. The implication of this discussion is that for these studies similar causality results would have been obtained if the MA representation had been used (subject to the provisos on orthogonalization given above).

Most of this discussion is couched in terms of 1-step Granger causality: indeed, for a bivariate or bivector system as described we can proceed directly to $\mathrm{h}$-step Granger causality, $\mathrm{h}=1,2 \ldots \infty$; see Lütkepohl (1993a), Lütkepohl and Müller (1994) and Dufour and Renault (1998). That is, when $\mathrm{z}_{\mathrm{t}}$ is partitioned as $\mathrm{z}_{\mathrm{t}}=\left(\mathrm{x}_{\mathrm{t}}{ }^{\prime}, \mathrm{y}_{\mathrm{t}}{ }^{\prime}\right)^{\prime}$, then the following three statements are equivalent (Dufour and Renault, 1998, Proposition 2.3): (i) 1-step $\mathrm{y}_{\mathrm{t}} \nrightarrow \mathrm{x}_{\mathrm{t}}$; (ii) h-step $\mathrm{y}_{\mathrm{t}} \nrightarrow \mathrm{x}_{\mathrm{t}}, \forall \mathrm{h}$; (iii) $\infty$-step $\mathrm{y}_{\mathrm{t}} \nrightarrow \mathrm{x}_{\mathrm{t}}$. That is, 1-step $\mathrm{y}_{\mathrm{t}} \nrightarrow \mathrm{x}_{\mathrm{t}}$ implies that $\mathrm{y}$ does not Granger-cause $\mathrm{x}$ two periods ahead, three periods ahead and so on. Non-causality one-period ahead is a necessary and sufficient condition for non-causality at all horizons. Thus, for the bivariate studies in Table A2 the causality results are implicitly for all horizons and not simply 1-step ahead as some authors suggest.

We now extend our discussion to allow $\mathrm{z}_{\mathrm{t}}$ to be partitioned into three subvectors as $\mathrm{z}_{\mathrm{t}}=\left(\mathrm{x}_{1 \mathrm{t}}{ }^{\prime}\right.$, $\left.\mathrm{x}_{2 \mathrm{t}}{ }^{\prime}, \mathrm{x}_{3 \mathrm{t}}{ }^{\prime}\right)^{\prime}$, where $\mathrm{x}_{1 \mathrm{t}}$ has dimension $\mathrm{K}_{1} \geq 1, \mathrm{x}_{2 \mathrm{t}}$ has dimension $\mathrm{K}_{2} \geq 1, \mathrm{x}_{3 \mathrm{t}}$ has dimension $\mathrm{K}_{3} \geq 0$ and $\mathrm{K}_{1}+\mathrm{K}_{2}+\mathrm{K}_{3}=\mathrm{K}$. We consider Granger non-causality from $\mathrm{x}_{1 \mathrm{t}}$ to $\mathrm{x}_{2 \mathrm{t}}$ in this system there are auxiliary variables in $\mathrm{x}_{3}$ employed for prediction but which are not involved in the causality study. We write the MA representation and corresponding $\operatorname{VAR}(\mathrm{p})$ process, assuming invertibility, as:

$$
\begin{gathered}
\mathrm{z}_{\mathrm{t}}=\left[\begin{array}{l}
\mathrm{x}_{1 \mathrm{t}} \\
\mathrm{x}_{2 \mathrm{t}} \\
\mathrm{x}_{3 \mathrm{t}}
\end{array}\right]=\left[\begin{array}{l}
\mu_{1} \\
\mu_{2} \\
\mu_{3}
\end{array}\right]+\left[\begin{array}{lll}
\phi_{11}(\mathrm{~L}) & \phi_{12}(\mathrm{~L}) & \phi_{13}(\mathrm{~L}) \\
\phi_{21}(\mathrm{~L}) & \phi_{22}(\mathrm{~L}) & \phi_{23}(\mathrm{~L}) \\
\phi_{31}(\mathrm{~L}) & \phi_{32}(\mathrm{~L}) & \phi_{33}(\mathrm{~L})
\end{array}\right]\left[\begin{array}{l}
\mathrm{u}_{1 \mathrm{t}} \\
\mathrm{u}_{2 \mathrm{t}} \\
\mathrm{u}_{3 \mathrm{t}}
\end{array}\right] \\
\mathrm{z}_{\mathrm{t}}=\left[\begin{array}{l}
\mathrm{x}_{1 \mathrm{t}} \\
\mathrm{x}_{2 \mathrm{t}} \\
\mathrm{x}_{3 \mathrm{t}}
\end{array}\right]=\left[\begin{array}{l}
\mathrm{v}_{1} \\
\mathrm{v}_{2} \\
v_{3}
\end{array}\right]+\sum_{\mathrm{i}=1}^{\mathrm{p}}\left[\begin{array}{lll}
\theta_{11, \mathrm{i}} & \theta_{12, \mathrm{i}} & \theta_{13, \mathrm{i}} \\
\theta_{21, \mathrm{i}} & \theta_{22, \mathrm{i}} & \theta_{23, \mathrm{i}} \\
\theta_{31, \mathrm{i}} & \theta_{32, \mathrm{i}} & \theta_{33, \mathrm{i}}
\end{array}\right]\left[\begin{array}{l}
\mathrm{x}_{1, \mathrm{t}-\mathrm{i}} \\
\mathrm{x}_{2, \mathrm{t} \mathrm{i}} \\
\mathrm{x}_{3, \mathrm{t}-\mathrm{i}}
\end{array}\right]+\left[\begin{array}{l}
\mathrm{u}_{1 \mathrm{t}} \\
\mathrm{u}_{2 \mathrm{t}} \\
\mathrm{u}_{3 \mathrm{t}}
\end{array}\right] .
\end{gathered}
$$

1-step Granger noncausality from $x_{1 t}$ to $x_{2 t}, 1$-step $x_{1 t} \nrightarrow x_{2 t}$, results when $\theta_{21, i}=0, i=1, \ldots, p$. However, when $m_{3} \geq 1$, this does not correspond to $\phi_{21, i}=0, i=1,2, \ldots$ in the MA representation (5); Dufour and Tessier (1993). That is, 1-step $\mathrm{x}_{1 \mathrm{t}} \nrightarrow \mathrm{x}_{2 \mathrm{t}}$ in the AR characterization is compatible with an innovation of $\mathrm{x}_{1}$ resulting in significant impulse responses and FEVDs for $\mathrm{x}_{2}$. Dufour and Tessier (1993) show that the exclusion restrictions $\theta_{21, i}=0, i=1, \ldots, p$ in the AR form correspond to nonlinear restrictions in the MA representation that depend on not only the impulse responses on the innovations of $x_{1}$ on $x_{2}$ but also those of $x_{1}$ on $x_{3}$, those of $x_{3}$ on $x_{2}$ and the own impulse responses of $x_{3}$. Conversely, from the MA representation zero impulses from an innovation on $x_{1}$ to $x_{2}\left(\phi_{21, i}\right.$ $=0, i=1,2, \ldots)$ implies nonlinear restrictions on the coefficients of the $\operatorname{VAR}(p)$ process involving the parameter matrices $\theta_{21}, \theta_{23}, \theta_{33}$ and $\theta_{31}$. So, even if the IRFs and FEVDs suggest noncausality there may still be Granger-causality in the AR representation. Consequently, in a system, which uses auxiliary variables for prediction purposes that are not involved in the causality question, the MA and 
AR representations do not yield equivalent notions of Granger non-causality. A decision is required as to which concept is under study - zero impulse response (and correspondingly zero FEVDs) or exclusion restrictions on the AR representation. If the latter is chosen, then zero impulse responses are not evidence of non-causality and nor is the proportion of the variance of $\mathrm{x}_{2}$ accounted for by the innovations of $x_{1}$ a measure of Granger causal priority from $x_{1}$ to $x_{2}$. This is important when comparing the results in Table A2 as $43 \%$ of the causality analyses employ a trivariate or higher-order system and of these 36 studies, 6 consider IRFs or FEVDs while the rest apply restrictions tests from the AR representation. For instance, Riezman et al. (1996) use annual data within a trivariate system and find many differences between the causality results from the AR and MA representations.

In the auxiliary variable system, can we extend these results directly from 1-step to h-step, $\mathrm{h}=1,2 \ldots$ ? Unfortunately, the answer is typically "no". In multivariate models where auxiliary variables $\left(\mathrm{x}_{3}\right)$ are drawn upon in addition to those involved in the causality analysis $\left(\mathrm{x}_{1}\right.$ and $\left.\mathrm{x}_{2}\right)$, it is possible that $\mathrm{x}_{1}$ does not 1-step Granger-cause $\mathrm{x}_{2}$ but can still help to predict $\mathrm{x}_{2}$ several periods ahead; see Sims (1980), Lütkepohl (1993b), Lütkepohl and Müller (1994) and Dufour and Renault (1998). For example, $\mathrm{x}_{1}$ may help to predict $\mathrm{x}_{2}$ two periods ahead, even though it is 1-step non-causal, because $\mathrm{x}_{1}$ may 1-step cause $\mathrm{x}_{3}$, which in turn 1-step causes $\mathrm{x}_{2}$. Clearly, our notions of causality should incorporate such indirect effects at longer horizons but the currently applied methods do not ${ }^{14}$. Consequently, care is needed when interpreting non-causality in a multivariate system, incorporating additional variables, as opposed to a bivariate system: the latter is testing for causality at all horizons while the former is not. Indirect effects are real possibilities in an exports-economic growth system and are not allowed for in the currently used methods of detecting causality. This point too is clearly crucial when studying Table A2 as it implies that differences between the bivariate and higher-order systems may be a facet of the implicit time horizons of the causality tests involved as well as differences due to information set. In the higher-order systems, do we expect causality to be limited to one-period ahead effects?

This section highlights the clear differences in interpreting Granger causality in a bivariate or bivector system and in a system that does not involve all variables in the causality question. These distinctions have not been recognized by the ELG empirical researchers and may well go some distance to explain many of the apparent conflicts in the literature. We now provide some other sources of difficulties.

1. Definition of the information set: The replacement of all relevant information by that only for the variables in the system leads to one common source of misspecification in a Granger causal analysis whether undertaken as a formal test of exclusion restrictions or via IRFs and FEVDs: the results may change for the $\mathrm{h}$-step forecast depending on the variables included in the information set. Aggregation of the data may also make a difference. If an annual system is studied and no causality is found from exports to GDP it does not follow that a corresponding quarterly exports has no impact on quarterly GDP. Likewise, employing seasonally adjusted variables in the information set may not produce the same causal outcome as using seasonally unadjusted variables. An illustration from Table A2 is testing for causality in Australia. Arnade \& Vasavada (1995) study, which examines for

14

The restrictions involved in allowing for multi-step or long-horizon causality are typically nonlinear. Some testing suggestions are provided in Dufour and Renault (1998) and Lütkepohl and Müller (1994). Application of these to the ELG hypothesis is beyond the scope of this paper. 
causality in a trivariate system involving annual data on real agricultural output and agricultural exports, suggests noncausality; ELG is put forward by Paul \& Chowdhury (1995) with annual data on real GDP and exports in a bivariate study; Bodman (1996) uses quarterly, seasonally adjusted data on manufacturing output and exports in a bivariate examination and detects evidence for ELG; Karunaratne (1996) detects ELG when using quarterly seasonally adjusted data in a 4-variable system with real GDP per capita and exports per capita; non-causality arises from the Pomponio (1996) bivariate investigation involving annual data on manufactured output and exports; Riezman et al. ₹ (1996) analysis with annual data on GDP and export growth suggests GLE in their bivariate model but non-causality in their trivariate system; Karunaratne (1997) in an expanded 6-variable study with quarterly, seasonally adjusted data reports evidence supporting bidirectionality while Shan \& Sun (1998a) in a 5-variable system with quarterly, seasonally adjusted data assert evidence for GLE. The varying outcomes may well be due to different information sets as well as dissimilar time periods and methods.

2. Estimation and lag-order selection: Let $\mathrm{z}_{\mathrm{t}}$ be a stable, K-dimensional VAR(p) process with white noise disturbances $\mathrm{u}_{\mathrm{t}}$ and with fourth moments of $\mathrm{u}_{\mathrm{t}}$ which exist and are bounded. Then, estimation of the parameters of the VAR(p) model by least squares (with common lag structure $p$ ) is equivalent to seemingly unrelated regression estimation and the LS estimator of the VAR parameters is consistent and asymptotically normal. Consequently, a Wald or LR (or LM) test statistic for the validity of exact linear restrictions has a limiting null $\chi^{2}$ distribution with degrees of freedom equal to the number of restrictions under test.

If the MA parameters are estimated recursively from the VAR coefficients and error covariance matrix then it follows that the resulting MA estimators are also consistent and asymptotically normal: Lütkepohl (1993a, Sec. 3.7). Consequently, the estimated impulse responses are asymptotically normal. Note however (Lütkepohl, 1993a, pp.101-2) that unfortunately this limiting distribution cannot be used for significance tests of the FEVDs: this perhaps limits their usefulness in causality testing, though some bootstrap to obtain standard errors.

Typically, of course, the VAR lag order is unknown. The usual approach is to either adopt an arbitrarily assigned value or to employ a data-based method. The choice of the lag length is important if we wish to avoid spurious causality (or spurious absence of causality). The finite-sample behavior of lag length determination methods (using information theoretic criteria as well as sequential testing approaches) has been studied theoretically and via simulation experiments. In this context, behavior $=$ is to be understood in the sense of maximizing the frequency of fitting a model with the true lag order. See, for example, Lütkepohl (1993a). Our survey of the ELG studies in Table A2 suggests that presetting the lag order and a group of model selection criteria are typical.

The impact of always under-specifying or over-specifying the lag order on the size and power of Granger non-causality tests on the VAR parameters is evaluated by by Toda and Phillips (1994), Dolado and Lütkepohl (1996), and Zapata and Rambaldi (1997). These results suggest that there can be serious distortions in presetting the lag order: parsimony in particular is not recommended. Giles and Mirza (1998), in their Monte Carlo investigation of the properties of Granger noncausality tests, allow for the lag order to be selected by sequential testing methods and two information criteria Schwarz (1978) criterion (SC) and Akaike (1969) Final Prediction Error (FPE) criterion. The findings of Giles and Mirza indicate some preference for the SC in lower dimensional systems but perhaps the FPE in larger systems. Typically, the distortions involved in applying databased lag order 
selection methods are not as serious as those involved in always under- or over- specifying the lag order. Further, these distortions are less than those which can arise from other, as yet to be discussed, sources. Hong Kong is an example of a country that is well studied with different techniques and lag order methods. The ten investigations in Table A2 that examine for causality in Hong Kong have preset the lag order and used the FPE and AIC model - outcomes include noncausality, ELG, GLE and bidirectional causality. These differences may be due to lag selection methods as well as other reasons.

Our discussion of lag selection methods is brief short as the currently available Monte Carlo evidence suggests that the impact of a different data-based selection criteria on the empirical size and power of Granger noncausality tests is relatively minor. Overestimation of the lag-order seems preferable. This may suggest use of criteria such as the AIC and FPE rather than the SC and HQ, as the former move away from the lowest possible lag order at a slow rate as the sample size increases (though both are consistent estimators of the lag order). The AIC and FPE are asymptotically equivalent and have a positive probability of overestimating the true lag order: evidence from Gonzalo and Pitarakis (1996) suggests that this probability of overestimation is relatively small. A discussion and comparison of the many other lag selection methods is beyond the scope of this paper.

2. Non-stationarity: We have so far limited our attention to stationary, stable systems: that is, processes that have time invariant first and second moments. This excludes trends or shifts in the means or in the covariances or seasonal patterns. However, we may expect the VAR to have nonstationary elements (unit roots and possibly cointegration). These characteristics do not alter the definitions of noncausality either within the AR or MA representation, nor will the presence of unit roots change the relationship between VAR coefficients, IRFs and FEVDs.

Nonstationarity will alter the asymptotic distributional results of the LS estimators of the coefficients and so test statistics for causality may or may not have standard asymptotic distributions. These features have lead researchers away from the use of unrestricted VAR models to employing differenced VARs or error correction models (ECMs): however, how the nonstationarity is dealt with matters.

For this discussion we suppose that a Wald test is employed to test the validity of the exclusion restrictions in an unrestricted VAR (we call this a levels VAR or LVAR): a noncausality conclusion results from support for the null hypothesis. Unfortunately, the asymptotic null distribution of the Wald test statistic depends on the time series features in the LVAR system. LS estimation of the LVAR coefficients in the presence of unit roots is asymptotically efficient but second-order biased (Phillips, 1992a,b; 1995). The usual Wald statistic for noncausality may involve a singular covariance matrix which may result in a nonstandard asymptotic null distribution (Toda and Phillips, 1993, 1994); and a LS regression involving variables with unit roots may give rise to a spurious regression (Granger and Newbold, 1974). Correspondingly, the estimates of IRFs and FEVDs obtained from unrestricted VARs with unit roots are also inconsistent; the estimates tend to random matrices (Phillips, 1998). These features suggest that noncausality testing should not be undertaken within a VAR model which may have unit roots (and cointegration) and nor should IRFs and FEVDs be generated from such unrestricted nonstationary VARs. Scholars responded by assuming explicitly that the time series under study were nonstationary and could be made stable by differencing or by introducing preliminary tests for unit roots into their analyses.

Engle and Granger 1987 paper changed the direction of empirical macroeconomics by 
introducing the concept of cointegration and the notion that variables which are cointegrated have an error correction representation. To formalize this we write the MA representation (1) in its LVAR(p) form, noting that for simplicity we have at this stage removed deterministic components:

$$
\mathrm{z}_{\mathrm{t}}=\theta(\mathrm{L}) \mathrm{z}_{\mathrm{t}-1}+\mathrm{u}_{\mathrm{t}}
$$

where $\theta(\mathrm{L})=\sum_{\mathrm{i}=1}^{\mathrm{p}} \theta_{\mathrm{i}} \mathrm{L}^{\mathrm{i}-1}$, with $\mathrm{L}$ the usual lag operator and $\theta_{\mathrm{i}}, \mathrm{i}=1, \ldots, \mathrm{p}$ are $\mathrm{K} \times \mathrm{K}$ parameter matrices. We assume that the system is initialized at $\mathrm{t}=\mathrm{p}+1 \ldots 0$ and the initial values can be any random vectors including constants. Applying the first-difference operator $\Delta$, defined by $\Delta \mathrm{z}_{\mathrm{t}}=\mathrm{z}_{\mathrm{t}}-\mathrm{z}_{\mathrm{t}-1}$, (7) can be written as a vector error correction model (VECM):

$$
\Delta \mathrm{z}_{\mathrm{t}}=\Pi \mathrm{z}_{\mathrm{t}-1}+\Gamma_{1} \Delta \mathrm{z}_{\mathrm{t}-1}+\ldots+\Gamma_{\mathrm{p}} \Delta \mathrm{z}_{\mathrm{t}-\mathrm{p}+1}+\mathrm{u}_{\mathrm{t}}
$$

where, $\Pi=-\left(\mathrm{I}-\theta_{1}-\ldots-\theta_{\mathrm{p}}\right), \Gamma_{\mathrm{i}}=\theta_{\mathrm{i}+1}+\ldots+\theta_{\mathrm{p}}, \mathrm{i}=1, \ldots, \mathrm{p}-1$. We assume $\Delta \mathrm{z}_{\mathrm{t}}$ is stationary and that $\operatorname{det}(\mathrm{I}-$ $\left.\theta_{1} \mathrm{w}-\ldots-\theta_{\mathrm{p}} \mathrm{w}^{\mathrm{p}}\right)$ has all its roots outside the complex unit circle except for possibly some unit roots. The nonstationary characteristics of $z_{t}$ can be determined from the rank of $\Pi$ (say $r$ ). There are three possibilities: (i) $r=n$; $\Pi$ has full rank, $z_{t}$ is integrated of order zero $(\mathrm{I}(0)$ ). The LVAR system is stationary. (ii) $r=0 ; \Pi$ is the null matrix; $z_{t} \sim I(1)$ with noncointegration. The LVAR system is nonstationary. (iii) $0<\mathrm{r}<\mathrm{n}$; $\Pi$ is of reduced rank and can be decomposed as $\Pi=\alpha \beta^{\prime}$, where $\alpha$ and $\beta$ are full-rank $\mathrm{K} \times \mathrm{r}$ matrices. $\beta$ is the cointegrating matrix with $\beta^{\prime} \mathrm{z}_{\mathrm{t}}$ stationary; $\alpha$ measures the rate of adjustment of the process $z_{t}$ to the disequilibrium error $\beta^{\prime} z_{t}$. This system has (n-r) unit roots and $r$ cointegrating vectors. In this case the unrestricted LVAR may sometimes still be used for valid Wald testing of the noncausality hypothesis. Likewise, the ECM (8) may provide a means to consistently estimate the VAR coefficients, the IRFs and FEVDs and for valid testing of the noncausal null.

When there is cointegration, Toda and Phillips $(1993,1994)$ show that the Wald test for noncausality in the LVAR(p) will have its standard limiting $\chi^{2}$ null distribution if there is Aufficient@ cointegration with respect to the causal effects being tested. Explicitly suppose as before, that $\mathrm{z}_{\mathrm{t}}$ is partitioned as $\mathrm{z}_{\mathrm{t}}=\left(\mathrm{x}_{1 \mathrm{t}}{ }^{\prime}, \mathrm{x}_{2 \mathrm{t}}{ }^{\prime}, \mathrm{x}_{3 \mathrm{t}}{ }^{\prime}\right)^{\prime}$, and we test 1-step $\mathrm{x}_{3 \mathrm{t}} \rightarrow \mathrm{x}_{1 \mathrm{t}}$ from the AR model. Then cointegration is Aufficient@Toda and Phillips, 1993, Corollary 1) if $\operatorname{rank}\left(\beta_{3}\right)=\mathrm{K}_{3}$, where $\beta_{3}$ is the last $\mathrm{K}_{3}$ rows of the cointegrating matrix $\beta$. So, for example, in a bivariate system the presence of cointegration is always sufficient and so estimation and testing for noncausality may be undertaken using an LVAR. The mere presence of cointegration in a trivariate or higher-dimensional system is not sufficient for valid use of an LVAR: there must be adequate cointegration of the right sort! Ansufficient@eintegration results in the Wald statistic in an estimated LVAR having a nonstandard limiting distribution that may depend on nuisance parameters. Unfortunately, Toda and Phillips are unable to provide a satisfactory means of testing the rank condition on $\beta_{3}$ for Aufficient@ cointegration. Consequently, attention has focused on testing for noncausality using the VECM. Note, first, that if there is noncointegration, (8) reduces to a classical first-differenced VAR, a $\operatorname{DVAR}(\mathrm{p}-1)$. Second, note that estimation of a DVAR(p-1) when there is cointegration involves a misspecification: the omission of the relevant cointegration information. The effects on parameter estimates and test properties follow from the classical results on the exclusion of variables.

Under our assumptions, (8) is a stable, stationary system and the noncausality exclusion restrictions on (7) map directly to restrictions on the appropriate elements of $\Pi, \Gamma_{1} \ldots \Gamma_{\mathrm{p}-1}$. Suppose 
we estimate the VECM by the maximum likelihood method suggested by Johansen (1988). Then, (Toda and Phillips, 1993, 1994) the Wald statistic of the null hypothesis for 1-step $\mathrm{x}_{3 \mathrm{t}} \nrightarrow \mathrm{x}_{1 \mathrm{t}}$ on the VECM parameters will have its limiting $\chi^{2}$ distribution provided $\operatorname{rank}\left(\alpha_{1}\right)=\mathrm{K}_{1}$ or $\operatorname{rank}\left(\beta_{3}\right)=\mathrm{K}_{3} . \alpha_{1}$ is the first $K_{1}$ rows of $\alpha$. That is, any cointegration must be of an appropriate kind. In the bivariate case the mere presence of cointegration is sufficient but in higher-dimensional systems the causal variables must be adequately involved in the cointegration. If either of the rank conditions is not satisfied then nuisance parameters and nonstandard distributions enter the limit theory. Toda and Phillips provide sequential testing strategies for examining for Aufficient@ointegration in the VECM.

Given the uncertainties of testing for noncausality within a LVAR, the usual route taken is to apply the following pretesting strategy: 1 . Test for unit roots. 2a. If $z_{t}$ is deemed stationary, then estimate an LVAR and proceed to the noncausality study. $2 \mathrm{~b}$. If $\mathrm{z}_{\mathrm{t}}$ is determined nonstationary then test for cointegration. $3 \mathrm{~b}(\mathrm{i})$. If no cointegration is found then estimate a DVAR model and proceed to the noncausality examination. $3 \mathrm{~b}$ (ii). If cointegration is detected then study noncausality within a VECM or LVAR. None of the papers in Table A2 examine whether any cointegration is sufficient, but theoretically from Toda and Phillips 3b(ii) should indeed be: 3b(ii) If cointegration is detected then test for Aufficient@ointegration, and then noncausality (see Toda and Phillips, 1993, 1994). $54 \%$ of the papers in Table A2 applied variants of this sequential testing strategy but it is fraught with potential problems. For instance, it is well known that typically applied unit root and cointegration tests suffer from size distortion and often have low power. This suggests that an appropriate model may not be used for the noncausality testing. Giles and Mirza (1998) Monte Carlo study on the properties of causality procedures indicates that often this pretesting route is not satisfactory. In many common types of situations the pretesting strategy leads to severe over-rejection of a noncausal null - often more so than in a classical standard LVAR, even if the processes are nonstationary! That is, pretesting for nonstationarity before the noncausality test can often lead to wrong conclusions of causality. Their results also demonstrate that the method adopted to pretest for nonstationarity is crucial.

What does this imply for IRFs and FEVDs from VECMs? Phillips (1998) shows that the VECM will produce consistent and asymptotically normal estimates of the IRFs and FEVDs, provided that the cointegrating rank is correctly specified or consistently estimated ${ }^{15}$. However, there is only limited Monte Carlo evidence on the finite sample performance of the pretesting strategies on the properties of the estimates of the IRFs and FEVDs.

Are there alternatives? Toda and Yamamoto (1995) and Dolado and Lütkepohl (1996) propose a technique that avoids the preliminary tests for unit roots and cointegration and is applicable irrespective of the integration or cointegration present in the system. The aim is to remove the singularity involved in the asymptotic distributions of the LS estimators by fitting an LVAR process whose order exceeds the true order by the highest degree of integration in the system. If the true lag order is $\mathrm{p}$ we estimate an $\operatorname{LVAR}(\mathrm{p}+1)$ if the highest degree of integration in the system is one, irrespective of the presence of cointegration. The test for noncausality then involves only the first $\mathrm{p}$ lags as the $(\mathrm{p}+1)$ coefficients are zero if they are indeed redundant: then the Wald test statistic

15

For example, classical likelihood ratio tests, as in Johansen $(1988,1991)$ consistently estimate the cointegrating rank (provided that the test size goes to zero as the sample size goes to infinity) and another possibility is order selection methods like those used in Phillips (1994) or Gonzalo and Pitarakis (1996). Note that consistent estimation of the lag order of the VAR is not necessarily required. 
maintains its limiting $\chi^{2}$ null distribution. The cost of redundant information is efficiency and power losses though available Monte Carlo evidence suggests that the power losses for the Wald noncausality test are relatively minor in trivariate or higher-order systems, for moderate to large sample sizes (say greater than 100), and for systems in which the true lag order is large. The study undertaken by Giles and Mirza (1998) also shows that this overfitting method performs consistently well over a wide range of systems including near-integrated, stationary and mixed integrated and stationary systems: cases for which the pretesting approaches tended to over detect causality.

There are seventy-four investigations in Table A2 which employ some form of VAR model to explore for causality between exports and economic growth. Of these, 10\% adopt a VAR in the levels of the data; a differenced VAR without pretests for nonstationarity is considered by another $30 \%$; $3 \%$ (i.e. 2 studies) apply some other operator to transform the data without nonstationarity pretests; 54\% use the pretesting strategy outlined above (but none test for Aufficient@ointegration); while only 3 studies apply the overfitting method proposed by Toda and Yamamoto (1995) and Dolado and Lütkepohl (1996). The analyses that employ levels VAR models in the raw data may well suffer from spurious regression problems as the series under study are typically believed to be nonstationary and consequently incorrect noncausality null distributions have been applied. Likewise, the application of first-differenced VAR models may be misspecified if the series are cointegrated as then potential causality from the long-run relationship has been omitted. The majority of studies adopt a pretesting approach typically estimating an ECM or a DVAR depending on the outcome of prior tests for unit roots and cointegration. Of those that specified their pretesting methods, the majority applied the Augmented Dickey-Fuller (ADF) test (Dickey and Fuller, 1979, 1981; Said and Dickey, 1981) as the unit root pretest and either Engle and Granger₹ (1987) ADF test or a variant of Johansen flikelihood ratio procedure for the cointegration test. Unfortunately, these methods can often lead to incorrect conclusions.

3. Deterministic terms: This is an important question that is ignored by virtually all of the studies in Table $\mathrm{A} 2^{16}$ : what deterministic constants and trends should be included? How should they be included? What difference does it make? Needless to say, it matters and the economic implications differ. Limiting our attention to deterministic components that consist of constants and linear trend terms we can extend the LVAR and VECM process (7) as:

$$
z_{t}=\mu+\delta t+\theta(L) z_{t-1}+u_{t}
$$

and

$$
\Delta \mathrm{z}_{\mathrm{t}-1}=\Pi \mathrm{z}_{\mathrm{t}-1}+\sum_{\mathrm{i}=1}^{\mathrm{p}-1} \Gamma_{\mathrm{i}} \Delta \mathrm{z}_{\mathrm{t}-1}+\mu+\delta \mathrm{t}+\mathrm{u}_{\mathrm{t}}
$$

where $\mu$ and $\delta$ are $K \times 1$ parameter vectors and $t=1,2, \ldots$. Let the number of cointegrating vectors be $\mathrm{r}>0$ so that $\Pi=\alpha \beta^{\prime}$. Denote $\delta_{\mathrm{t}}=\mu+\delta \mathrm{t}+\alpha \beta^{\prime} \mathrm{z}_{\mathrm{t}}$. The MA representation can be written as (see correction (EC) term and, with and without a linear trend term. He concludes (p685) A.the specification matters for the causality test results. The inclusion of the error-correction terms and/or the time trend have changed the p-values and the F-statistics considerably in most cases, although the basic results do not depend on the specification.@ 
Johansen, 1991, Theorem 4.1 and Johansen, 1994):

$$
\mathrm{z}_{\mathrm{t}}=\mathrm{A}+\mathrm{W}_{\mathrm{t}}+\tau_{0}+\tau_{1} \mathrm{t}+0.5 \tau_{2} \mathrm{t}^{2}+\mathrm{C} \sum_{\mathrm{i}=1}^{\mathrm{t}} \mathrm{u}_{\mathrm{i}}
$$

in which $\mathrm{W}_{\mathrm{t}}$ is a stationary process; $\mathrm{A}$ is a vector such that $\beta^{\prime} \mathrm{A}=0 ; \mathrm{C}=\beta_{\perp}\left(\alpha_{\perp}^{\prime} \Theta \beta_{\perp}\right)^{-1} \alpha_{\perp}$ with $\Theta=\mathrm{I}_{\mathrm{K}}-\sum_{\mathrm{i}=1}^{\mathrm{p}-1} \theta_{\mathrm{i}}, \beta_{\perp}$ a K $\times(\mathrm{K}-\mathrm{r})$ matrix of full rank orthogonal to $\beta$, and $\alpha_{\perp}$ likewise defined. $\tau_{2}=\mathrm{C} \delta$. Comparing (9), (10) and (11) we see that a constant term in the nonstationary VAR gives rise to a linear trend in the process while a linear trend in the model results in a trend of either degree one or two depending on the relations between $\alpha$ and $(\mu+\delta t)$. That is, cointegration can lead to various different trending processes. Five cases are commonly considered:

Case 0: $\delta_{\mathrm{t}}=\alpha \beta^{\prime} \mathrm{z}_{\mathrm{t}-1} \cdot \mathrm{z}_{\mathrm{t}}$ has no deterministic terms and all of the stationary components have zero mean.

Case $1^{*}: \delta_{\mathrm{t}}=\alpha\left(\beta^{\prime}, \beta_{0}\right)\left(\mathrm{z}_{\mathrm{t}-1}^{\prime}, 1\right)^{\prime} ; \beta_{0}=\left(\alpha^{\prime} \alpha\right)^{-1} \alpha^{\prime} \mu . \mathrm{z}_{\mathrm{t}}$ has neither a quadratic nor linear trend from (11) though $z_{\mathrm{t}}$ has a constant via the cointegrating relations, which here are given by ( $\beta^{\prime}$, $\left.\beta_{0}\right)\left(\mathrm{z}_{\mathrm{t}-1}^{\prime}, 1\right)^{\prime}$ : each of the latter is a level stationary process, which is one that is composed of a stationary process and a constant term.

Case 1: $\delta_{\mathrm{t}}=\mu+\alpha \beta^{\prime} \mathrm{z}_{\mathrm{t}-1}$. $\mathrm{z}_{\mathrm{t}}$ has a linear trend but it is not present in the cointegrating relations. The model consists of (K-r) variables that are comprised of I(1) variables and a linear trend, and $\mathrm{r}$ stationary variables.

Case $2^{*}: \delta_{\mathrm{t}}=\mu+\alpha\left(\beta^{\prime}, \beta_{0}\right)\left(\mathrm{z}_{\mathrm{t}-1}^{\prime}, \mathrm{t}\right)^{\prime} . \mathrm{z}_{\mathrm{t}}$ has a linear trend which is also present in the cointegrating relations : each of the latter is a trend stationary process, which is one that can be decomposed as a stationary process plus a linear trend.

Case 2: $\delta_{\mathrm{t}}=\mu+\delta \mathrm{t}+\alpha \beta^{\prime} \mathrm{z}_{\mathrm{t}-1} . \quad \mathrm{z}_{\mathrm{t}}$ has a quadratic trend but the cointegrating relations have a linear trend only.

The statistical analysis for cointegration, and therefore for causality, depends on which case is adopted. This choice needs to be made from economic considerations or, at least, from a statistical examination. We illustrate that the issue should not be ignored in section 4 .

\subsection{ELG empirical time series studies}

In the last section we provided some information about the time series techniques used to test for ELG and we briefly mentioned some empirical work. We present further details in this section. We would ideally like to provide a country by country description but as this is infeasible we concentrate on discussing two countries in detail to illustrate the spectrum of results that have been obtained - South Korea ${ }^{17}$ and Japan, both of which are extensively represented in Table A2. Details are provided in Tables 1 and 2. In these tables we report information on method, estimation period, and results. Abbreviations adopted in the tables are described at the beginning of the appendix. 


\subsubsection{South Korea}

Table 1 outlines thirty-six empirical works that examine for the relationship between exports and economic growth in South Korea. Of these, eleven estimate a form of aggregate production function models while the others examine for causality via a VAR framework. The former studies include bivariate and multivariate analyses with the multivariate work attempting to account for other factors which may contribute to economic growth, including investment, government spending, population/employment growth. The aggregate production studies employ annual data and of these, eight authors report a significant export/economic growth effect, while the others detect no significant relationship. A sensitivity analysis may be helpful to detect the reasons behind some of the conflicting results. Two of the papers, which did not discern a significant relationship, investigate per capita economic growth and the third (Salvatore and Hatcher, 1991) includes as a regressor real industrial production growth: these features may be those that distinguishes them from the others. The Salvatore and Hatcher result may be supportive of the view expressed by Sheehey (1990) that the positive correlation occurs with other categories of economic activity and consequently this aggregate approach may not be a fruitful way to isolate the impact of one particular sector on economic activity. The data period does not seem to be a determining factor as the three non-supportive applications employ time spans similar to some of the supportive papers.

Typically, the production function type regressions are estimated in terms of growth rates or first differences of the variables, which are likely to be stationary representations of the series. Consequently, these regressions are not estimating long-run relationships. One might regard them as indicating patterns of instantaneous causality among the stationary representations, though it is usual to test for instantaneous causality conditional on the past history of the series and via the error terms. Many of the criticisms of the aggregate production function approach outlined in section 3 also apply here. In particular, the Accounting identity@problem; endogeneity and specification issues; and the distinction between statistical association and causation. The observed significant correlations are compatible with ELG, GLE or Bidirectional (BD) causality.

Turning to the VAR research, the four cases of ELG, GLE, BD and NC (noncausality) are all represented! Only five of these twenty-five case examinations use quarterly data. Interestingly, the five quarterly studies reach the same conclusion of BD causality. Restrictions tests on the VAR coefficients are undertaken by the four bivariate quarterly applications while the sole multivariate quarterly analysis evaluates FEVD \& IRFs from the moving average representation derived from the estimated autoregressive model. Accordingly, these papers are effectively considering more that oneperiod ahead causality. The bivariate investigation of Gupta (1985) uses a Sims =est rather then the Granger test we outlined in section 3.1. The basis of Sims=est is that the vector y can be expressed as a distributed lag function of current and past values of the vector $\mathrm{x}$ with a residual which is not correlated with any values of $x$, past or future, if and only if, $y$ does not cause $x$ in Granger sense. We can test this via a regression of $y$ on past and future values of $x$ with the outcome of causality supported if the hypothesis that the parameters attached to the future values of $\mathrm{x}$ are simultaneously zero, is rejected. Sims ₹ test and Granger ₹ test may not give the same causality outcome but do so here. All except Gupta (1985) model effectively with the growth rates of real GDP and exports; Gupta uses an alternative ARIMA transformation to obtain stationarity ${ }^{18}$. Only two of the papers

\footnotetext{
${ }^{18}$ Note that Atukeren (1994) shows that the Accounting identity@roblem does not affect Granger noncausality
} tests. 
undertake preliminary tests for cointegration with both applying the EG-ADF test and arriving at contrasting conclusions. This could be due to different information sets, including time periods. Several methods are adopted to determine the lag structure such as the FPE criterion, a specific to general approach and presetting the lag order, and various time periods are covered including 1960 (1):1979(4) and 1973(1):1993(2). Even given these differences, we observe a common outcome of bidirectional causality between exports and economic activity.

Robustness is not a feature of the annual investigations. There we find support for ELG from seven studies; four determine GLE; five report BD causality and the remaining ten advocate NC. (Note that several examinations employ more than one procedure.) In analyzing this literature the reader should note two points. First, several authors seem to believe that there can be no ELG if there is nonointegration and consequently conclude that there is no causality in these cases. It is clear, however, from section 3.1 that causality can arise from the short-run dynamics as well as from the long-run relationship. That is, it is a misconception to conclude that noncointegration implies noncausality. Secondly, some papers detect cointegration within a bivariate framework and then report noncausality: this is not a feasible outcome. Within the error correction framework, (linear) cointegration implies (linear) causality in at least one direction in a bivariate system. This need not follow in a multivariate system, as the cointegrating relationship(s) need not involve the variables connected with the noncausality test.

Bivariate studies dominate the annual South Korean analyses with only eleven trivariate or higher order systems. The information set and method seem to matter: for example, Riezman et al. (1996) report GLE from their bivariate analysis; ELG from one trivariate (with real import growth) method; GLE from another trivariate method but NC from their 5-variable study of South Korea over the same time period. We look at now the bivariate investigations for which there are some commonalities. Several studies adopting similar time spans covering the late 1950s to mid 1980s, report noncausality with each effectively applying a DVAR model in the log-levels of real GDP and exports (without pretests for cointegration). These models are misspecified if there is a long-run relationship between exports and GDP and the causality effect from that long-run relationship is missed. Dutt and Ghosh (1996) and Kugler and Dridi (1993) propose that there is cointegration between these two variables though Dutt and Ghosh (1994) adopting an alternative cointegration test do not support this conclusion. These differences explain some of the variation in the outcomes for the bivariate cases. Method matters as well. For example, Hsiao (1987) reports BD causality from Sims approach but noncausality from the Granger test. Time period may also be relevant; for example, Hodman and Graves (1995) determine BD causality from a bivariate DVAR over the period 1953:1990 applying Granger s test in contrast to the similar models above which found noncausality.

Turning to the multivariate investigations, it is difficult to determine the reasons behind the various outcomes. Four papers model with DVARs without pretests for cointegration and each employs different sets of variables as well as time periods - two studies report noncausality; one ELG and the other BD causality from 1-step ahead Granger exclusion restriction tests. Riezman et al. (1996) likewise conclude ELG from their trivariate FEVDs but GLE from an alternative approach to causality testing suggested by Geweke (1984). In a 5-variable system they detect evidence of no causality - so their analysis describes ELG, GLE and NC effects for South Korea depending on method and information set! Three of the South Korean multivariate studies pretest for cointegration: two apply Johansen maximum likelihood approach and reach opposite conclusions, though one considers Case $1 *$ while the other Case 1 . The EG-ADF approach is also employed in 
the 7-variable system of Ghatak (1998) to conclude support for cointegration and evidence for ELG. Ghatak reports the same outcome from a Bayesian VAR procedure but not from a levels-VAR model. The latter result may be driven by misspecification of the null distribution of the noncausality test statistic in the nonstationary system as there is no discussion of whether the cointegration is Aufficient@r not.

\subsubsection{Japan}

Twenty studies are presented in Table 2. Of these, four are OLS production function analyses while a VAR framework is adopted by the other applications. Six of the VAR investigations estimate DVAR models without prior testing for cointegration; five studies undertake a pretest for cointegration before deciding whether to employ a DVAR or ECM(or LVAR) model; FEVD f from DVARs are reported in two papers; three VAR applications base their conclusions for ELG solely on whether cointegration is present or not; and one paper examines the overfitting method of testing for noncausality from the levels VAR model.

Three of the four production function papers determine that there is no significant relationship between export growth and economic activity. The data period covered is the key distinguishing feature between these cases and the sole production function study which detects a significant relationship: the latter are over the period 1885:1940 while the former investigations are from the late 1950s. The comments we raised in the previous section pertaining to the reliability of the results from these examinations apply equally well here. We refer the reader back to these remarks.

Seven VAR studies employ quarterly data with most covering the period from the late 1950s to late 1980s and one examining for causality from the mid 1970s to late 1990s. Bidirectional causality is the main outcome for the earlier time period and unfortunately the study which considered the more recent period only examined for unidirectional causality from exports to growth with no causality detected. Five of the applications explore for causality within a 4-variable framework with most concluding a BD result, which seems surprising as one might expect the 1-period ahead prediction requirement for quarterly data to be restrictive. An interesting comparison is available from the Sharma et al. (1991) and Marin (1992) papers. Both adopt the same time period and 4variable Granger causality but different information sets. Marin examines for causality between labor productivity defined as manufacturing output per employee and real exports of manufactured goods while Sharma et al. use the broader GDP and total exports. Marin detects cointegration and tests for causality within an ECM while Sharma et al. apply a DVAR model without pretests. Marin determines BD whereas Sharma et al. only ELG. Are the outcomes due to variable differences and/or model specification? This comparison highlights the potential sensitivity of the causality test to the variable specifications and to the adopted method/model.

The bivariate annual Granger causality investigations for Japan typically support GLE rather than BD causality, though Islam (1998) concludes ELG, Boltho (1996) reports that there is some evidence of BD causality if the subgroup of car exports is studied rather than total exports, and Pomponio (1996) detects noncausality between manufacturing output and exports growth. Islam result may be driven by variable differences as he considers the proportion of export earnings in GDP and non-export GDP while the others adopt real GDP and real exports. Variable definitions may explain Pomponio inconsistent outcome, as well as a shorter, more recent time period. Boltho result is important: very few cases disaggregate exports or GDP and it makes sense that this might be a fruitful way to proceed. 
Time periods overlap for the multivariate VAR investigations - 1952:80, 1950:90, 1961:87, 1965:85 and 1967:91. Further, the definitions of economic growth and export growth are dissimilar for the five multivariate Japan cases. For instance, Arnade and Vasavada (1995) determine noncausality in their study with real agricultural output and agricultural exports while Grabowski et al. (1990) propose ELG when using real GDP and exports along with three additional predictive variables. Consequently, it is not surprising that the causality results include ELG, GLE and NC. Some examinations detect cointegrating relationships while others do not. The ancillary variables range from import growth to a set comprising the share of non-defense expenditures in GDP, imports as a share of GDP and total investment share of GDP. Is there evidence to suggest 1-step ELG in Japan with annual data? Conditional on the details of the analysis this may be so.

\section{Sensitivity analysis: empirical examples of Portugal and Canada}

Our discussion of some of the empirical work highlighted the potential sensitivity of the causality results to the estimation period, lag selection technique, economic growth and export growth definitions, auxiliary variables, and to other pretests undertaken to arrive at a final model specification. However, as most of the studies varied by more than one of these items it was not possible to strictly determine what was causing the change in the causality outcomes. Our aim in this section is to undertake a small sensitivity analysis for the Granger causality test in the ELG case. As a full sensitivity analysis would add substantially to an already long paper, we limit our attention to nonrobustness due to method and model; so we consider only one sample period, a limited information set and one lag selection method ${ }^{19}$. We restrict attention to Wald coefficient tests on the VAR formulation of the system, though our expectation is that similar nonrobustness results would occur from tests undertaken via the moving average representation such as those from IRFs and FEVDs.

To undertake this part of our study we reconsider the data used by Oxley (1993) for Portugal and Henriques and Sadorsky (1996) for Canada. That we draw upon these two studies should not be interpreted to imply our criticism of their work: on the contrary, both of these studies were quite rigorous in their investigations. They were chosen merely because the authors of these papers obligingly provided us with their data. It is our belief that the features we observe with these two data sets would result with any of the data sets in the literature. The Portugal data are bivariate while that for Canada are trivariate. For the latter we present bivariate and trivariate results. As our aim is to study robustness issues we do not spend space discussing the trade policies and relevant economic issues for these countries - we recognize the merits of this for a detailed individual country application.

\subsection{Method matters}

In this section we illustrate that modifying the testing method and information set can change the causality conclusion. We restrict our attention to pretests for cointegration. We recognize that unit root tests are typically undertaken as well but their impact is well researched in the literature.

19

Others have argued that noncausality tests are sensitive to the functional form structure of the estimating

equations, to the lag structure specified, to the approach used to obtain white-noise, and to variable misspecification (e.g., Feige and Pearce, 1979; Jacob et al., 1979; Roberts and Nord, 1985; Sephton, 1989). 
To limit scope we assume that the data series in their log-levels are integrated of order one: this is a reasonable assumption from prior research. We focus on three cointegration tests and we examine causality using a Wald test for exclusion restrictions from the VAR representation. For this exercise we adopt a $\chi^{2}$ approximation for the finite sample null distribution - the results may differ with other finite sample approximations.

Given its popularity we examine Johansen maximum likelihood approach (JJML), limiting attention to the maximum eigenvalue test statistic and the Engle-Granger ADF approach (Engle and Granger, 1987). The null hypothesis is for noncointegration and so we include also a test which has cointegration as the null - McCabe et al. (1997) cointegration test (MLS test). Following recommendations in Leybourne and McCabe (1997) correlation in the system is allowed for via a data dependent parametric method. Due to space constraints we omit details of the tests here ${ }^{20}$. The usual approach with residual based cointegration tests is to include a constant in the static cointegrating regression and so we adopt Case $1 *$ as outlined in section 3.1. That is, when cointegrated, $\mathrm{z}_{\mathrm{t}}$ consists of (K-r) I(1) variables and $r$ level stationary variables. For the trivariate model we present results for the JJML approach which does not test for sufficient cointegration and for the Toda and Phillips (1993, 1994) method which includes a pretest for sufficient cointegration: we call the latter TP. We follow the recommendation of Toda and Phillips (1994) and use their strategy $\mathrm{P}^{21}$.

We use the $\mathrm{AIC}^{22}$, from the log-levels unrestricted VAR, to select the lag order - others have pointed out that this choice may affect the outcome of the cointegration and noncauasality tests. We compare the pretesting methods with the overfitting method suggested by Toda and Yamamoto (1995) and Dolado and Lütkepohl (1996) adding one additional lag given our assumption of I(1) variables. The Wald statistic for noncausality is then formed directly from the overfitted LVAR model. For the residual based cointegration tests we build the Wald statistic from either a DVAR model or from an ECM depending on the outcome of the cointegration test: for the latter, the residuals from the static cointegrating regression form the error correcting terms. In the case of Johansen approach the Wald statistic is generated from a DVAR model if no cointegration is detected, from a LVAR if full rank is supported and from an ECM model if reduced rank is favored. In the latter case the Wald statistic is constructed from the maximum likelihood estimates of the ECM, applying the normalization of Johansen (1988), by converting back to the LVAR estimates as outlined in Lütkepohl (1993a) for instance. The TP estimates are obtained from the same maximum likelihood estimates as JJML. We assume iid errors within equations of the VAR but we allow for contemporaneous correlation across equations.

\footnotetext{
20

They are available on request.

21

Suppose we wish to test that $\mathrm{x}_{3 t}$ noncauses $\mathrm{x}_{1 \mathrm{t}}$. Let $\mathrm{r}$ * be the estimated cointegrating rank, $\alpha_{1}$ be the first row of $\alpha$ and is of dimension $\mathrm{r}^{*}, \beta_{3}$ be the last row of $\beta$ and let the relevant $\Gamma$ parameters for the causal test be $\gamma_{1} \ldots \gamma_{\mathrm{p}-1}$. Then strategy P1 of Toda and Phillips (1993) is test $\mathrm{H}_{1}: \alpha_{1}=0$ via a Wald test statistic which is asymptotically $\chi^{2}\left(\mathrm{r}^{*}\right)$ under the null. If $\mathrm{H}_{1}$ is rejected, then test $\mathrm{H}_{2}: \gamma_{1}=\ldots=\gamma_{\mathrm{p}-1}=0 \& \alpha_{1} \beta_{3}=0$ via a Wald test statistic which is asymptotically $\chi^{2}(\mathrm{p})$ under the null; otherwise test $\mathrm{H}_{3}: \gamma_{1}=\ldots=\gamma_{\mathrm{p}-1}=0$ via a Wald test statistic which is asymptotically $\chi^{2}(\mathrm{p}-1)$ under the null.

22 Akaike (1973) information criterion. $\mathrm{AIC}(\mathrm{p})=\log |\mathrm{w}(\mathrm{p})|+2$ (\# of freely estimated parameters)/T, w(p) is the estimated matrix of scalar covariance terms with lag order $\mathrm{p}$ and $\mathrm{T}$ is the sample size. We allow for a maximum lag order of 8 years.
} 


\subsubsection{The Canadian data set}

The Canadian data set is trivariate - real exports (X), real GDP (Y) and real terms of trade $(\mathrm{T})$, defined as export unit value over import unit value. The annual data set, investigated in logarithmic form, spans 1877 to 1991: Henriques and Sadorsky (1996) study the periods 1877-1945; 1946-1991 and 1877-1991. We examine the latter period only, recognizing, though ignoring, potential problems of structural breaks. Table 3 summarizes the bivariate and trivariate results for testing for ELG and GLE using the Wald exclusions test within the autoregressive system. The AIC lag order is four for both the bivariate and trivariate models. The numbers in Table 3 are p-values for the Wald statistics assuming a limiting $\chi^{2}$ null distribution.

The results are not dependent on dimension for the cases presented in Table 3. The overfitting method and MLS pretest approach favor no ELG or GLE. The EG-ADF procedure suggests no ELG but strong support for GLE while the JJML pretest method indicates strong evidence of bidirectional causality. One reason for the contradicting results is the different estimates of whether there is cointegration. The EG-ADF and JJML pretests imply cointegration and in the trivariate system there is evidence for two cointegrating vectors. Another source of explanation for the contrasting outcomes are misspecification errors - if there is cointegration then the MLS pretest technique is undertaking the noncausality tests in an underspecified model - the cointegration effects having been omitted. The noncausality outcome with this method could be due to this specification error. If so, then the overfitting results are also incorrect - this may arise from the loss in power in estimating a model with redundant lags.

However, the simulation experiments in Dolado and Lütkepohl (1996) and Giles and Mirza (1998) suggest that the loss in power, when overfitting, is quite small in samples of the size we are considering and in systems of the order being estimated here. Further, Giles and Mirza (1998), from the wide range of data generating processes considered, advocate that the overfitting method is more consistent at obtaining the correct causality conclusion than any of the studied pretest methods. Their simulation experiments show many cases when the EG-ADF and JJML methods obtain invalid cointegration conclusions. Consequently, the support for causality may be a consequence of such misspecifications. Irrespective of reasons, the results in Table 3 display the nonrobustness of causality conclusions to method.

\subsubsection{The Portugese data set}

Oxley 1993 annual data on real exports and real GDP for Portugal covers 1865 to 1991. We employ the full bivariate data set and transform each series into natural logarithms. The effects of structural breaks on the procedures are left for future work. The AIC implies five lags for the unrestricted log-levels bivariate system with a constant term. Table 4 reports the p-values from the three pretesting methods and the overfitting approach for the Wald noncausality tests assuming an asymptotic $\chi^{2}$ null. We do not use the TP approach here as cointegration in a bivariate system is sufficient.

We again observe variation in outcome due to procedure. All four methods support GLE while the JJML technique is the only one to imply bidirectional causality. Interestingly, the MLS pretest suggests noncointegration while the EG-ADF and JJML both favor the presence of a cointegrating relationship: nevertheless, the MLS and EG-ADF procedures still reached the same causality conclusions. 


\subsection{Deterministic components}

In this section we illustrate, by means of the Canadian and Portugese data, the impact of the choice of deterministic components. Our sensitivity analysis shows that changing the deterministic trends in the model specification can alter the causality outcome. We limit our attention here to the JJML and TP pretest approaches and to the overfitting method of Toda and Yamamoto (1995) and Dolado and Lütkepohl (1996), which remains valid with deterministic terms. We deal with Cases 0,1, $1^{*}, 2$ and $2^{*}$ outlined in section 3.1. The AIC is again applied to select the lag order with the unrestricted log-levels VAR augmented by appropriate deterministic components. The optimal lag orders did not change for the two data sets.

\subsubsection{The Canadian data set}

Table 5 provides the estimated asymptotic p-values for the maximum eigenvalue likelihood ratio tests for cointegrating rank for both the bivariate and trivariate models. Irrespective of the choice of deterministic components, in the bivariate case there is strong support for one cointegrating vector. In the trivariate case, there is typically evidence for two cointegrating vectors - information set affects the cointegrating rank - however, allowing for trend terms can eliminate the basis for one of the cointegrating relationships. The p-values, assuming a limiting $\chi^{2}$ null distribution, for the resulting Wald noncausality tests are presented in Tables $6 \mathrm{a}$ and $6 \mathrm{~b}$. We see that the overfitting method does not support a causal connection between gdp and exports for the several combinations of deterministic components and information set. The JJML and TP conclusions, on the other hand, vary with deterministic terms and information set. In the bivariate model all cases advocate GLE while ELG is endorsed for Case 0 and Case $1^{*}$ but not for Cases $1,2^{*}$ and 2 . The inclusion of the terms of trade variable eliminates backing for ELG in Case 0 and we no longer contend GLE for Cases 2 and $2 *$. Recall, though, that in the trivariate model we are limiting our attention to 1-step causality: the conclusions may change if multi-step causality were to be investigated. Nevertheless, across the trivariate cases we no longer support 1-step GLE when linear trends are included in the model.

\subsubsection{The Portugese data set}

Estimated asymptotic p-values for the maximum eigenvalue cointegrating rank test are reported in Table 7 . These imply a strong basis for one cointegrating vector except for Case $2 *$ : the latter imposes a trend stationary cointegrating relationship. We illustrate the effect on the noncausality tests of setting $\mathrm{r}^{*}=1$ or $\mathrm{r}^{*}=0$ for Case $2^{*}$ by undertaking the noncausality tests employing a DVAR(4) and an $\operatorname{ECM}(4)$. The p-values for the Wald noncausality tests are given in

Table 8: we assume a limiting $\chi^{2}$ null distribution. Regardless of method and case, we conclude there is GLE. However, there is minimal evidence for ELG. There is some justification via the overfitting method when there are no deterministic terms in the model - this may be spurious causality from the omission of relevant deterministic components as inclusion of the latter eliminates the ELG support. All ECM models advocate bidirectional causality: the JJML approach is either overrejecting noncausality or the overfitting approach is lacking power. Both are possibilities here. Note additionally for Case $2 *$ that the omission of the error correction term alters the ELG conclusion and illustrates the importance of the specification of the cointegrating rank. 


\section{Concluding Remarks}

In this paper we have attempted to provide comprehensive information on the empirical research that investigates the export-led growth hypothesis, and to indicate the range of methods applied to examine this hypothesis. We are certain to have made omissions, but hopefully our survey is indicative of the dimension of the empirical literature. It is evident that there is no obvious agreement on the ELG debate. We have moreover demonstrated from applications for Canada and Portugal that the extensively used noncausality techniques to examine for causation between exports and overall economic activity are not robust. This is discouraging as it suggests that it is easy to obtain alternative outcomes. Furthermore, our sensitivity study implies that applied researchers need to exercise extreme care when testing for causality to avoid spurious results: indiscriminate application of such tests is not recommended. Hopefully, some of the information we provided will assist researchers in this direction.

Our examples in section 4 illustrated the effect of the choice of deterministic trending terms on the noncausality outcome. Part of the difficulty for the pretesting approaches that undertake a cointegration test, is that the result of the pretest crucially depends on the assumed deterministic trends in the system. It is even more complicated than we portrayed as the conclusions from the cointegration pretest and noncausality test are sensitive to the lag order. One practical way to proceed with the pretest strategy is to select simultaneously the cointegrating rank, the lag length and the applicable deterministic trends. The information criteria adopted to ascertain the lag order can be readily extended for this task. Let $\mathrm{P}=\mathrm{K}(\mathrm{r}+(\mathrm{p}-1) \mathrm{K}+\mathrm{d})$ be the number of fitted parameters for the $\mathrm{ECM}$ with $\mathrm{r}$ denoting the cointegrating rank and $\mathrm{d}$ the number of parameters for the deterministic trending process including the constant term. Then we can augment the AIC and SC criteria, for example, as $\operatorname{AIC}(\mathrm{p}, \mathrm{r}, \mathrm{d})=\log |\mathrm{w}|+2 \mathrm{~N} / \mathrm{T}$ and $\mathrm{SC}(\mathrm{p}, \mathrm{r}, \mathrm{d})=\log |\mathrm{w}|+\mathrm{N} \log (\mathrm{T}) / \mathrm{T}$; where $\mathrm{w}$ is the estimate of the covariance matrix of the VAR. Phillips (1996) proposes a Bayesian model determination criteria explicitly for this problem. Phillips=posterior information criteria (PIC) is defined as $\operatorname{PIC}(\mathrm{p}, \mathrm{r}, \mathrm{d})=\log |\mathrm{w}|+(\log |\Theta| / \mathrm{T})$, where the penalty factor $|\Theta|$ is a function of the dimension of the model and the observed data. It would be straightforward to code the determination of $\mathrm{p}, \mathrm{r}$ and $\mathrm{d}$ by such approaches into standard computer packages.

The sensitivity analysis showed as well that causality testing and innovation accounting are unlikely to be robust with the currently applied pretesting approaches. Accurate determination of the cointegrating rank is crucial for such methods to be useful and the currently popular tests do not seem adequate. Some hope may lie in the methods that avoid unit root and cointegration pretesting or in other more precise techniques to determine the cointegrating rank. Monte Carlo simulations suggest that the overfitting idea of Toda and Yamamoto (1995) and Dolado and Lütkepohl (1996) result in noncausality outcomes that are less sensitive than the commonly employed pretesting strategies. However, the overfitting procedure loses efficiency and power from the inclusion of the redundant lags. Other methods which may improve upon current techniques include proposals from Lütkepohl and Burda (1997), Phillips=(1995) FM-VAR method and its extensions (e.g., Kitamura, 1994; Quintos, 1998). Such methods may assist in obtaining more robust noncausality outcomes.

Further, the time series models currently employed to test for export-led growth are dominated by linear VAR models and yet the theory is available to eliminate many of the limitations of these models. Examples include extensions to incorporate moving average terms and removal of the linearity assumption. It has long been recognized that moving average processes are common in 
economic systems and yet none of the export-led growth empirical literature allows for this. Testing for Granger causality in VARMA models involves nonlinear restrictions on the autoregressive and moving average parameters, though in some instances sufficient conditions for noncausality can be expressed as linear constraints (see, for instance, Lütkepohl, 1993; Boudjelleba et al., 1994). There are many nonlinear models of potential interest. Granger and Swanson (1996) and Balke and Fomby (1997), for instance, discuss nonlinear generalizations of cointegration and ECMs that may provide interesting possibilities for the export-led growth question. Other prospects include regime-switching VAR models (see Warne , 1996, for conditions for Granger 1-step noncausality in such models); smooth transition regressions (e.g., Teräsvirta, 1998); stochastic unit root models (e.g., Granger and Swanson, 1997; Swanson and Franses, 1997). McCabe and Leybourne (1997) allow for stochastic cointegration and Siklos and Granger (1997) propose regime sensitive cointegration. These relaxations of current assumptions in the linear VAR model may offer attractive options in the exportled growth debate. Extending beyond 1-step prediction in trivariate or higher dimensional systems would likewise appear obvious for future research. It is reasonable to believe that the cause and effect in any export growth - economic growth relation could take longer than a few quarters or even years..

The majority of papers in our survey focus on broad macroeconomic data and yet there is grounds for attention to less aggregated variables. For instance, Fosu (1990), Giles et al. (1992), Boltho (1996), Ghatak et al. (1997) and Tuan \& Ng (1998) detect different conclusions for sector decompositions than at the broad macro level. Bernard and Jensen (1997) focus on firm data to ascertain whether good firms become exporters or whether exporting improves firm performances. We believe that much could be learned about the export-led growth question by assessing microbased data.

Furthermore, we advise researchers to conduct a careful qualitative analysis prior to embarking on empirical statistical testing; for instance, Boltho (1996) and Tuan and Ng (1998). Noncausality methods do not allow for the heterogeneity and complexity of the historical changes in economic and institutional policies that are likely to impact on the export/economic growth nexus for a country over time. To quote Kindleberger (1961) study (p.305) AVe conclude, as we began, that expanding or contracting foreign trade,..., can have an impact on growth, ..., but that the relationships between foreign trade and growth are varied and complex.@This statement is still appropriate and we believe that statistical tests should be employed as supplementary information in an export-led growth examination. Aside from the limitations of the methods that we have displayed in this paper, we need to remember that evidence for (Granger) causality is simply advocacy for an improvement in predictability and not for general economic development strategies. 


\section{References}

Abhayaratne, A.S.P. (1996) Foreign trade and economic growth evidence from Sri Lanka, 19601992'. Applied Economics Letters 3, 567-70.

Adelman, I. (1984) Beyond export-led growth=World Development 12, 937-49.

Afxentiou, P.C. and Serletis, A. (1989) Æong term trends in Canadian economic development= Economic Notes 3, 362-75.

Afxentiou, P.C. and Serletis, A. (1991a) Exports and GNP causality in the industrial countries: 19501985'. Kyklos 44, 167-79.

Afxentiou, P.C. and Serletis, A. (1991b) Exports in the Canadian economic development'. Economic Notes 20, 354-66.

Ahmad, J. and Harnhirun, S. (1992) The causality between exports and economic growth in the ASEAN countries - cointegration and error correction model approach=Mimeo., Department of Economics, Concordia University.

Ahmad, J. and Harnhirun, S. (1995) Đnit roots and cointegration in estimating causality between exports and economic growth: empirical evidence from the ASEAN countries=Economics Letters 49, 329-34.

Ahmad, J., Harnhirun, S. and Yang, J. (1997) Export and economic growth in the ASEAN countries: cointegration and causality tests =International Review of Economics and Business 44, 41930 .

Ahmad, J. and Kwan, A.C.C. (1991) Eausality between exports and economic growth: empirical evidence from Africa=Economics Letters 37, 243-48.

Akaike, H. (1969). Fitting autoregressive models for prediction=Annals of the Institute of Statistical Mathematics 21, 243-7.

Akaike, H. (1973) Ænformation theory and an extension of the maximum likelihood principle=In B.N. Petrov and F. Csáki (eds.) $2^{\text {nd }}$ International Symposium on Information Theory. Budapest: Académiai Kiadó.

Alam, M.S. (1991) Ғrade orientation and macroeconomic performance in LDCs: an empirical study= Economic Development and Cultural Change 39, 839-48.

Al-Yousif, Y.K. (1997) Exports and economic growth: some empirical evidence from the Arab Gulf countries =Applied Economics 29, 263-7.

Amin Gutiérrez de Piñeres, S. and Ferrantino, M. (1997) Đxport diversification and structural dynamics in the growth process: a case study of Chile=Journal of Development Economics 52, 375-91.

Amin Gutiérrez de Piñeres, S. and Ferrantino, M. (1998) Export sector dynamics and domestic growth: the case of Colombia=Review of Development Economics forthcoming.

Amirkhalkhali, S. and Dar, A.-A. (1995) A varying-coefficients model of export expansion, factor accumulation and economic growth: evidence from cross-country, time series data $=$ Economic Modelling 12, 435-41.

Amoateng, K. and Amoako-Adu,B. (1996) Economic growth, export and external debt causality: the case of African countries =Applied Economics 28, 21-7.

Arnade, C. and Vasavada, U. (1995) Eausality between productivity and exports in agriculture: evidence from Asia and Latin America=Journal of Agricultural Economics 46, 174-86. 
Atesoglu, H.S. (1994) An application of a Kaldorian export-led model of growth to the United States =Applied Economics 26, 479-83.

Atukeren, E. (1994) A note on the tests of Granger-causality between exports and economic growth=Applied Economics Letters 1, 207-9.

Bagchi, A. (1982) The Political Economy of Underdevelopment. Cambridge: Cambridge University Press.

Bahmani-Oskooee, M. and Alse, J. (1993) Æxport growth and economic growth: an application of cointegration and error correction modeling =The Journal of Developing Areas 27, 535-42.

Bahmani-Oskooee, M. and Domac, I. (1995) Export growth and economic growth in Turkey: evidence from cointegration analysis= Middle East Technical University Studies in Development 22, 67-77.

Bahmani-Oskooee, M., Mohtad, H. and Shabsigh, G. (1991) Exports, growth and causality in LDCs: a re-examination=Journal of Development Economics 36, 405-15.

Balassa, B. (1978a) Đxports and economic growth: further evidence=Journal of Development Economics 5, 181-9.

Balassa, B. (1978b) Export incentives and export performance in developing countries: a comparative analysis =Weltwirtschaftliches Archiv 114, 24-61.

Balassa, B. (1981) The Newly Industrializing Countries in the World Economy. New York: Pergamon Press.

Balassa, B. (1982) Development Strategies in Semi-industrialized Economies. New York: Oxford University Press.

Balassa, B. (1984) Adjustment to external shocks in developing economies= World Bank Staff Working Paper 472. Washington, DC : The World Bank,.

Balassa, B. (1985) Exports, policy choices, and economic growth in developing countries after the 1973 oil shock = Journal of Development Economics 18, 23-35.

Balassa, B. (1989) Đutward orientation= In H. Chenery and T.N. Srinivasan (eds.) Handbook of Development Economics, Volume II. Amsterdam: Elsevier.

Balke, N.S. and Fomby, T.B. (1997) Fhreshold cointegration=International Economic Review 38, 627-45.

Ben-David, D. and Loewy, M.B. (1996) 'Free-trade and long-run growth'. Mimeo., Foerder Institute for Economic Research, Te-Aviv University.

Bhagwati, J.N. (1986) Rethinking trade strategy=In J.P. Lewis and V. Kallab (eds.) Development Strategies Reconsidered. New Brunswick: Transaction Books.

Bhagwati, J.N. (1988a) Protectionism. Cambridge, MA : MIT Press.

Bhagwati, J.N. (1988b) Đxport-promoting trade strategy: issues and evidence= World Bank Research Observer 3, 27-57.

Bhagwati, J.N. and Srinivasan, T.N. (1978) ¥rade policy and development=In R. Dornbusch and F.A. Frenkel (eds.) International Economic Policy: Theory and Evidence. Baltimore, MD:: Johns Hopkins University Press.

Blumenthal, T. (1972) Đxports and economic growth: the case of postwar Japan=Quarterly Journal of Economics 86, 617-31.

Bodman, P.M. (1996) $\bigoplus$ n export-led growth in Australia and Canada: cointegration, causality and structural stability=Australian Economic Papers 35, 282-99. 
Boltho, A. (1996) \#as Japanese growth export-led?=Oxford Economic Papers 48, 415-32.

Boudjellaba, H., Dufour,J.-M. and Roy, R. (1994) >Simplified conditions for noncausality between vectors in multivariate ARMA models'. Journal of Econometrics 63, 271-287.

Brander, J.A. and Spencer, B.J. (1985) Æxport subsidies and international market share rivalry= Journal of International Economics 18, 83-100.

Bruton, H. (1989) >्रmport substitution= In H. Chenery and T.N. Srinivasan (eds.) Handbook of Development Economics Vol. 2. Amsterdam: North Holland.

Buffie, E.F. (1992) Đn the condition for export-led growth=Canadian Journal of Economics 25, 211-25.

Burney, N.A. (1996) Exports and economic growth: evidence from cross country analysis=Applied Economics Letters 3, 369-73.

Caves, R.E. (1970) Đxport-led growth: the post-war industrial setting= In Eltis, W.A., Scott, M.F.G. and Wolfe, J.N. (eds.) Induction, Growth and Trade: essays in Honor of Sir Roy Harrod. London: Oxford University Press.

Chenery, H.B. and Strout, A. (1966) Foreign assistance and economic development=American Economic Review, 679-732.

Cheng, B.S. and Chu, O. (1996) Ð.S. exports and economic growth causality=Atlantic Economic Journal 24, 263.

Chow, P.C.Y. (1987) Eausality between export growth and industrial development: empirical evidence from the NICs=Journal of Development Economics 26, 55-63.

Cline, W. (1984) Exports of Manufactures from Developing Countries. Washington: Brookings Institute.

Cooley, T.F. and Le Roy, S.F. (1985) Atheoretical macroeconometrics: a critique=Journal of Monetary Economics 16, 283-308.

Coppin, A. (1994) Đeterminants of LDC output growth during the 1980s=Journal of Developing Areas 28, 219-28.

Corden, W.M. (1987) Protection and liberalization: a review of analytical issues=IMF Occasional Paper No. 54.

Cornwall, J. (1977) Modern Capitalism: Its Growth and Transformation. New York: St Martin₹ Press.

Darrat, A.F. (1986) Frade and development: the Asian experience=Cato Journal 6, 695-9.

Darrat, A.F. (1987) Are exports an engine of growth? Another look at the evidence=Applied Economics 19, 277-83.

De Gregorio, J. (1992) Æconomic growth in Latin America=Journal of Development Economics 39, 59-84.

Dhananjayan, R.S. and Devi, N.S. (1997) Æxports and economic growth: a study of select nations in Asia and Europe during 1980-81 to 1993-94= Indian Journal of Applied Economics 6, 41-63.

Dickey, D.A. and Fuller, W.A. (1979) Đistributions of the estimators for autoregressive time series with a unit root=Journal of the American Statistical Association 74, 427-81.

Dickey, D.A. and Fuller, W.A. (1981) Đikelihood ratio statistics for autoregressive time series with a unit root=Econometrica 49, 1057-72.

Dodaro, S. (1991) Eomparative advantage, trade and growth: export-led growth revisited=World Development 19, 1153-65. 
Dodaro, S. (1993) Æxports and growth: a reconsideration of causality=Journal of Developing Areas 27, 227-44.

Dolado, J.J. and Lütkepohl, H. (1996) Making Wald tests work for cointegrated VAR systems= Econometric Reviews 15, 369-86.

Dollar, D. (1992) Đutward-oriented developing economies really do grow more rapidly: evidence from 95 LDCs, 1976-1985'. Economic Development and Cultural Change 40, 523-44.

Doraisami, A. (1996) Đxport growth and economic growth: a reexamination of some time-series evidence of the Malaysian experience= Journal of Developing Areas 30, 223-30.

Doyle, E. (1998) Export-output causality: the Irish case, 1953-1993'. Atlantic Economic Journal 26, forthcoming.

Dufour, J.-M. and Renault, E. (1998) Short run and long run causality in time series: theory= Econometrica 66, 1099-125.

Dufour, J.-M. and Tessier, D. (1993) Đn the relationship between impulse response analysis, innovation accounting and Granger causality= Economics Letters 42, 327-33.

Dutt, S.D. and Ghosh, D. (1994) An empirical investigation of the export growth-economic growth relationship=Applied Economics Letters 1, 44-8.

Dutt, S.D. and Ghosh, D. (1996) The export growth-economic growth nexus: a causality analysis= Journal of Developing Areas 30, 167-82.

Edwards, S. (1993) Đpenness, trade liberalization and growth in developing countries $=$ Journal of Economic Literature 31, 1358-93.

Egwaikhide, F.O. (1992) Đil export and economic growth in Nigeria: a preliminary investigation= Indian Journal of Economics 72, 221-32.

Emery, R.F. (1967) The relation of exports and economic growth $=$ Kyklos 20, 470-86.

Engle, R.F. and Granger, C.W.J. (1987) Eointegration and error correction: representation, estimation and testing $=$ Econometrica 55, 251-76.

Engle, R.F. and Hendry, D.F. (1993) Festing superexogeneity and invariance in regression models= Journal of Econometrics 56, 119-39.

Engle, R.F., Hendry, D.F. and Richard, J.F. (1983) Đxogeneity=Econometrica 51, 277-304.

Esfahani, H.S. (1991) Exports, imports, and economic growth in semi-industrialized countries= Journal of Development Economics 35, 93-116.

Eswaran, M. and Kotwal, A. (1993) Export led development: primary vs. industrial exports=Journal of Development Economics 41, 163-72.

Fajana, O. (1979) ¥rade and growth: the Nigerian experience=World Development 7, 73-8.

Feder, G. (1983) Đn exports and economic growth =Journal of Development Economics 12, 59-73.

Feige, E.L. and Pearce, D.K. (1979) The causal relationship between money and income: some caveats for time series analysis=Review of Economics and Statistics 61, 521-33.

Findlay, C. and Watson, A. (1996) Economic growth and trade dependency in China=DP \#9615, Chinese Research Centre, University of Adelaide.

Findlay, R. (1984) Erowth and development in trade models=In Jones, R. and Kenen, P.B. (eds.) Handbook of International Economics, Vol.1. Amsterdam: North Holland.

Flam, H. and Helpman, E. (1987) łndustrial policy under monopolistic competition=Journal of International Economics 22, 79-102. 
Fosu, A.K. (1990) Exports and economic growth: the African case=World Development 18, 831-5. Fosu, A.K. (1996) Primary exports and economic growth in developing countries= World Economy $19,465-75$.

Fuller, W. and Batesse, G. (1974) Estimation of linear models with crossed error structure=Journal of Econometrics 2, 67-78.

Gani, A. (1997) Đconomic growth in Papua New Guinea: some empirical evidence= Pacific Economic Bulletin 12, 41-52.

Geweke, J.R. (1984) Measures of conditional linear dependence and feedback between time series= Journal of the American Statistical Association 79, 907-15.

Geweke, J.R., Meese, R.A. and Dent, W. (1983) Eomparing alternative tests of causality in temporal systems: analytic results and experimental evidence= Journal of Econometrics 21, 161-94.

Ghatak, A. (1998) $¥$ ector-autoregression modeling and forecasting growth of South Korea=Journal of Applied Statistics, forthcoming.

Ghatak, S., Milner, C. and Utkulu, U. (1997) Exports, export composition and growth: cointegration and causality evidence for Malaysia=Applied Economics 29, 213-23.

Ghartey, E.E. (1993) Eausal relationship between exports and economic growth: some empirical evidence in Taiwan, Japan and the U.S.=Applied Economics 25, 1145-52.

Giles, D.E.A., Giles, J.A. and McCann, E. (1992) Eausality, unit roots and export-led growth: the New Zealand experience=Journal of International Trade and Economic Development 1, 195-218.

Giles, J.A. and Mirza, S. (1998) Some pretesting issues on testing for Granger noncausality= Mimeo., Department of Economics, University of Victoria.

Gonçalves, R. and Richtering, J. (1987) \#ntercountry comparison of export performance and output growth=The Developing Economies 25, 3-18.

Gonzalo, J. and Pitarakis, J.-Y. (1996) łnferences on short and long run dynamics in small and large dimensional systems: a model selection perspective'. Mimeo., Department of Economics, University of Reading.

Gordon, D.V. and Sakyi-Bekoe, K. (1993) Festing the export-growth hypothesis: some parametric and non-parametric results for Ghana=Applied Economics 25, 553-63.

Grabowski, R. (1988) Early Japanese development: the role of trade, 1885-1940'. Quarterly Journal of Business and Economics 27, 104-29.

Grabowski, R. (1994) \#mport substitution, export promotion and the state in economic development= Journal of Developing Areas 28, 535-54.

Grabowski, R., Sharma, S.C. and Dhakal, D. (1990) Æxports and Japanese economic development= Economics Letters 32, 127-32.

Granger, C.W.J. (1963) Đconomic processes involving feedback = Information and Control 6, 2848.

Granger, C.W.J. (1969) ‡nvestigating causal relations by econometric models: cross spectral methods $=$ Econometrica 37, 424-38.

Granger, C.W.J. and Newbold, P. (1974) Spurious regressions in econometrics= Journal of Econometrics 2, 111-20.

Granger, C.W.J. and Swanson, N. R. (1996) Future developments in the study of cointegrated variables $=$ Oxford Bulletin of Economics and Statistics 58, 537-553. 
Granger, C.W.J. and Swanson, N. R. (1997) Æntroduction to stochastic unit root processes=Journal of Econometrics 80, 35-62.

Greenaway, D., Morgan, W. and Wright, P. (1997) Frade liberalization and growth in developing countries: some new evidence=World Development 25, 1885-92.

Greenaway, D. and Sapsford, D. (1994a) What does liberalization do for exports and growth= Weltwirtschaftliches Archiv 130, 152-74.

Greenaway, D. and Sapsford, D. (1994b) Æxports, growth, and liberalization: an evaluation=Journal of Policy Modelling 16, 165-86.

Grossman, G.M. and Helpman, E. (1991) Innovation and Growth in the Global Economy. Cambridge, MA : MIT Press.

Gupta, S. (1985) Export growth and economic growth revisited=Indian Economic Journal 32, 52-9.

Hamilton, N. and Thompson, C. (1994) Export promotion in a regional context: Central America and Southern Africa=World Development 22, 1379-92.

Hannan, E.J. and Quinn, B.G. (1979) The determination of the order of an autoregression=Journal of the Royal Statistical Society B41, 190-5.

Hansen, B.E. (1990) ^ powerful, simple test for cointegration using Cochrane-Orcutt=Working Paper, Boston College.

Hansen, P. (1994) The government, exporters and economic growth in New Zealand=New Zealand Economic Papers 28, 133-42.

Haring, J.E. (1963) Đynamic trade theory and growth in poor countries=Kyklos 16, 371-94.

Haring, J.E. and Humphrey, J.F. (1964) Simple models of trade expansion= Western Economic Journal 2, 173-4.

Hart, O. (1983) The market mechanism as an incentive scheme=Bell Journal of Economics 14, 36682.

Havrylyshyn, O. (1990) Frade policy and productivity gains in developing countries: a survey of the literature $=$ World Bank Research Observer 5, 1-24.

Helleiner, G.K. (1986) 'Outward orientation, import instability and African economic growth: an empirical investigation'. In Lall, S. and Stewart F. (eds.) Theory and Reality in Development: Essays in Honour of Paul Streeton. Hong Kong: MacMillan.

Heller, P.S. and Porter, R.C. (1978) Æxports and growth: an empirical re-investigation=Journal of Development Economics 5, 191-3.

Helpman, E. and Krugman, P.R. (1985) Market Structure and Foreign Trade. Cambridge (Mass.): MIT Press.

Henriques, I. and Sadorsky, P. (1996) Æxport-led growth or growth-driven exports? The Canadian case = Canadian Journal of Economics 96, 540-55.

Holman, J.A. and Graves, P.E. (1995) Korean exports economic growth: an econometric reassessment = Journal of Economic Development 20, 45-56.

Holmes, J.M. and Hutton, P.A. (1990) Small sample properties of the multiple rank F-test with lagged dependent variables=Economics Letters 33, 55-61.

Hotchkiss, J.L., Moore, R.E. and Rockel, M. (1994) Export expansion and growth at different stages of development=Journal of Economic Development 19, 87-105.

Hsiao, C. (1979) Autoregressive modelling of Canadian money and income data=Journal of the American Statistical Association 74, 553-60. 
Hsiao, M.W. (1987) Fests of causality and exogeneity between exports and economic growth: the case of Asian NICs = Journal of Economic Development 12, 143-159.

Hutchinson, M. and Singh, N. (1992) Exports, non-exports and externalities: a Granger causality approach=International Economic Journal 6, 79-94.

Islam, M.N. (1998) Đxport expansion and economic growth: testing for cointegration and causality= Applied Economics 30, 415-25.

Islam, M.N. and Iftekharuzzaman, M. (1996) Export-growth nexus in a small open economy: the case of Bangladesh =In Weis, C.E. and Wahid, A.N.M. (eds.) The Economy of Bangladesh: Problems and Prospects. Westport, CT: Praeger Publishing.

Jacob, R.L., Leamer, E.E. and Ward, M.P. (1979) Đifficulties with testing for causation'. Economic Inquiry 42, 401-13.

Jaffee, D. (1985) Æxport dependence and economic growth: a reformulation and respecification= Social Forces 64, 102-18.

Jin, J.C. (1995) Đxport-led growth and the four little dragons=Journal of International Trade and Economic Development 4, 203-15.

Jin, J.C. and Yu, E.S.H. (1995) The causal relationship between exports and income= Journal of Economic Development 20, 131-40.

Jin, J.C. and Yu, E.S.H. (1996) Export-led growth and the U.S. economy: another look=Applied Economics Letters 3, 341-4.

Johansen, S. (1988) Statistical analysis of cointegration vectors=Journal of Economic Dynamics and Control 12, 231-54.

Johansen, S. (1991) Æstimation and hypothesis test of cointegrating vectors in Gaussian vector autoregressive models $=$ Econometrica 59, 1551-80.

Johansen, S. (1994) The role of the constant and linear terms in cointegration analysis of nonstationary variables = Econometric Reviews 13, 205-29.

Johansen, S. and Juselius, K. (1990) Maximum likelihood estimation and inference in cointegration - with application to the demand for money=Oxford Bulletin of Economics and Statistics 52, 169-210.

Jung, S.W. and Marshall, P.J. (1985) Æxports, growth and causality in developing countries=Journal of Development Economics 18, 1-12.

Kaldor, N. (1964) Essays on Economic Policy. London: G. Duckworth.

Karunaratne, N.D. (1994) Erowth and trade liberalization in Australia: a VAR analysis= International Review of Economics and Business 41, 625-43.

Karunaratne, N.D. (1996) Erowth and trade dynamics under regime shifts in Australia =Journal of Economic Studies 23, 55-69.

Karunaratne, N.D. (1997) ¥ligh-tech innovation, growth and trade dynamics in Australia=Open Economies Review 8, 151-70.

Kavoussi, R.M. (1984) Export expansion and economic growth: further empirical evidence=Journal of Development Economics 14, 241-50.

Kavoussi, R.M. (1985) Fnternational trade and economic development: the recent experience of developing countries=Journal of Developing Areas 19, 379-92.

Keesing, D.B. (1967) Đutward-looking policies and economic development=Economic Journal 77, 303-20. 
Khan, A.H. and Saqib, N. (1993) Exports and economic growth: the Pakistan experience= International Economic Journal 7, 53-64.

Kindleberger, C.P. (1961) Foreign trade and economic growth: lessons from Britain and France=The Economic History Review, 289-305.

Kitamura, Y. (1994) \#ypothesis testing in models with possibly nonstationary processes= Mimeo., Department of Economics, University of Minnesota.

Kohli, I. and Singh, N. (1989) Æxports and growth: critical minimum effort and diminishing returns $=$ Journal of Development Economics 30, 391-400.

Kormendi, R.C. and Meguire, P.G. (1985) Macroeconomic determinants of growth: cross country evidence = Journal of Monetary Economics 16, 141-63.

Kravis, I.B. (1970) >Trade as a handmaiden of growth: similarities between the nineteenth and twentieth centuries =Economic Journal 80, 850-70.

Krueger, A.O. (1978) Foreign Trade Regimes and Economic Development: Liberalization Attempts and Consequences. Cambridge (Mass.): Balinger.

Krueger, A.O. (1980) Trade policy as an impact to development=American Economic Review 2, 288-92.

Krueger, A.O. (1985) The experience and lessons of Asia superexporters =In Corbo,V., Krueger, A.O. and Ossa, F. (eds.) Export-oriented Development Strategies: The Success of Five Newly Industrialized Countries. London: Westview Press.

Krueger, A.O. (1995) Trade Policies and Developing Nations. Washington: Brookings Institution.

Krugman, P.R. (1984) ¥mport protection as export promotion= In Kierzkowski, H. (ed.) Monopolistic Competition in International Trade. Oxford: Oxford University Press.

Krugman, P.R. (1987) ¥ free trade passe?=Economic Perspectives 1, 131-44.

Krugman, P.R. (1989) ‡ndustrial organization and international trade=In Schmalensee, R. and Willig, R. (eds.) Handbook of Industrial Organization Vol. 2. Amsterdam: North Holland.

Kugler, P. (1991) Erowth, exports and cointegration: an empirical investigation'. Weltwirtschaftliches Archiv 127, 73-82.

Kugler, P. and Dridi, J. (1993) Erowth and exports in LDCs: a multivariate time series study= International Review of Economics and Business 40, 759-67.

Kunst, R.M. and Marin, D. (1989) Øn exports and productivity: a causal analysis $=$ Review of Economics and Statistics 71, 699-703.

Kwan, A.C.C. and Cotsomitis, J.A. (1991) Economic growth and the expanding export sector: China 1952-1985'. International Economic Journal 5, 105-16.

Kwan, A.C.C., Cotsomitis, J.A. and Kwok, B. (1996) Exports, economic growth and exogeneity: Taiwan 1953-88'. Applied Economics 28, 467-71.

Kwan, A.C.C. and Kwok, B. (1995) Exogeneity and the export-led growth hypothesis: the case of China=Southern Economic Journal 61, 1158-66.

Kwiatkowski, D., Phillips, P.C.B., Schmidt, P. and Shin Y. (1992) Ғesting the null hypothesis of stationarity against the alternative of a unit root=Journal of Econometrics 54, 159-78.

Lal, D. and Rajapatirana, S. (1987) Foreign trade regimes and economic growth in developing countries =World Bank Research Observer 2, 189-217.

Lancaster, K. (1980) łntra-industry trade under perfect monopolistic competition=Journal of International Economics 10, 151-75. 
Leamer, E. (1985) $\Downarrow$ ector autoregressions for causal inference=Carnegie-Rochester Conference Series on Public Policy 22, 255-303.

Leybourne S.J. and B.P.M. McCabe (1997) Modified stationarity tests with data dependent model selection rules=Mimeo., Faculty of Commerce and Business Administration, University of British Columbia.

Little, I.M.D. Scitovsky, T. and Scott, M.F. (1970) Industry and Trade in Some Developing Countries: A Comparative Study. London: Oxford University Press.

Liu, X., Song, H. and Romilly, P. (1997) An empirical investigation of the causal relationship between openness and economic growth in China =Applied Economics 29, 1679-86.

Love, J. (1994) Engines of growth: the export and government sectors =World Economy 17, 203-18.

Lucas, R.E. (1988) $\oslash n$ the mechanics of economic development=Journal of Monetary Economics 22, 3-42.

Lütkepohl, H. (1993a) Introduction to Multiple Time Series Analysis, $2^{\text {nd }}$ Edition. Berlin: SpringerVerlag.

Lütkepohl, H. (1993b) Festing for causation between two variables in higher dimensional VAR models =In Schneeweiss, H. and Zimmerman, K. (eds.) Studies in Applied Econometrics. Heidelberg: Springer-Verlag.

Lütkepohl, H. and M.M. Burda (1997) Modified Wald tests under nonregular conditions=Journal of Econometrics 78, 315-32.

Lütkepohl, H. and M.M. Müller (1994) Ғesting for multi-step causality in time series= Working Paper, Institut für Statistik und Ökonometrie, Humboldt-Universität zu Berlin.

MacKinnon, J.G. (1994) Aumerical distribution functions for unit root and cointegration tests= Journal of Applied Econometrics 11, 601-618.

MacKinnon, J.G., Haug, A.A. and Michelis, L. (1996) Numerical distribution functions of likelihood ratio tests for cointegration=Mimeo., Department of Economics, Queen $₹$ University.

Maizels, A. (1963) Industrial Growth and World Trade. Cambridge: Cambridge University Press.

Maizels, A. (1968) Exports and Economic Growth of Developing Countries. Cambridge: Cambridge University Press.

Mallick, S.K. (1996) Eausality between exports and economic growth in India: evidence from cointegration based error correction models =Indian Journal of Economics 76, 307-20.

Marin, D. (1992) \$s the export-led growth hypothesis valid for industrialized countries=Review of Economics and Statistics 74, 678-88.

Mbaku, J.M. (1989) Đxport growth and economic performance in developing countries: further evidence from Africa=Journal of Economic Development 14, 127-42.

McCabe, B.P.M. and Leybourne, S.J. (1997) Stochastic Cointegration= Mimeo., Faculty of Commerce, University of British Columbia.

McCabe, B.P.M. and Leybourne, S.J., and Shin, Y. (1997) A parametric approach to testing the null of cointegration=Journal of Time Series Analysis 18, 395-413.

McCarville, M. and Nnadozie, E. (1995) Eausality tests of export-led growth: the case of Mexico'. Atlantic Economic Journal 23, 140-5.

McDonald, S. and Roberts, J. (1996) Misspecification and cross-country growth regressions'. Applied Economics Letters 3, 413-6. 
McKinnon, R. (1964) Foreign exchange constraint in economic development and efficient aid allocation=Economic Journal 74, 388-409.

McNab, R.M. and Moore, R.E. (1998) Frade policy, export expansion, human capital and growth= Journal of International Trade and Economic Development 7, 237-56.

Meier, G.M. (1984) Frade as an Angine of growth@ note=In Meier, G.M. (ed.) Leading Issues in Economic Development, 4th Edition. New York: Oxford University Press, 489-92.

Michaely, M. (1977) Exports and economic growth: an empirical investigation= Journal of Development Economics 4, 49-53.

Michalopoulos, C. and Jay, K. (1973) Growth of exports and income in the developing world: a neoclassical view $=$ DP. 28, US Agency of International Development, Washington DC.

Moore, R.E. (1992) The level of development and GSP treatment=Journal of World Trade 26, 1930.

Moschos, D. (1989) Export expansion, growth and the level of economic development: an empirical analysis=Journal of Development Economics 30, 93-102.

Mrydal, G. (1970) The Challenge of World Poverty. New York: Kingsport Press.

Nandi, S. and Biswas, B. (1991) Exports and economic growth in India: empirical evidence=Indian Economic Journal 38, 53-9.

Nurkse, R. (1961) Frade theory and development policy=In Ellis, H.S. (ed.) Economic Development of Latin America. New York: St Martin Press, 236-46.

Onafowora, O.A., Owoye, O. and Nyatepe-Coo, A.A. (1996) Frade policy, export performance and economic growth: evidence from Sub-Saharan Africa=Journal of International Trade and Economic Development 5, 341-60.

Onchoke, S.N. and In, F. (1994) An empirical investigation of long run relationships between export revenues and economic growth in the South Pacific Island Nations=Singapore Economic Review 38, 213-28.

Otani, I. and Villaneuva, D. (1990) Łong-term growth in developing countries and its determinants: an empirical analysis =World Development 18, 769-83.

Oxley, L. (1993) Eointegration, causality and export-led growth in Portugal, 1865-1985'. Economics Letters 43, 163-6.

Pack, H. (1988) łndustrialization and trade=In Chenery, H. and Srinivasan, T.N. (eds.) Handbook of Development Economics, Volume 1. Amsterdam: Elsevier.

Pack, H. (1992) Đearning and productivity changes in developing countries =In Helleiner, G.K. (ed.) Trade Policy, Industrialization and Development: New Prospectives. Oxford: Clarendon Press.

Papanek, G.F. (1973) Aid, foreign private investment, savings, and growth in less developed countries = Journal of Political Economy 81, 120-30.

Park, J.H. and Prime, P.B. (1997) Đxport performance and growth in China: a cross-provincial analysis=Applied Economics 29, 1353-63.

Park, J.Y. (1992) Eanonical cointegrating regressions=Econometrica 60, 119-43.

Paul, S. and Chowdhury, K. (1995) Export-led growth hypothesis: some empirical testing=Applied Economics Letters 2, 177-9.

Phillips, P.C.B. (1992a) ¥yperconsistent estimation of a unit root in time series regression= Cowles Foundation Discussion Paper \#1040. 
Phillips, P.C.B. (1992b) Simultaneous equation bias in level VAR estimation=Econometric Theory 8, 307. (Solution in Vol.9, 324-6.)

Phillips, P.C.B. (1994) ßayes models and forecasts of Australian macroeconomic time series'. In Hargreaves, C.P. (ed.) Nonstationary Time Series and Cointegration. Oxford: Oxford University Press.

Phillips, P.C.B. (1995) Fully modified least squares and vector autoregression=Econometrica 63, 1023-78.

Phillips, P.C.B. (1996) Æconometric model determination= Econometrica 64, 763-812.

Phillips, P.C.B. (1998) ¥mpulse response and forecast error variance asymptotics in nonstationary VARs = Journal of Econometrics 83, 21-56.

Phillips, P.C.B. and Ouliaris, S. (1990) Asymptotic properties of residual based tests for cointegration $=$ Econometrica $58,165-93$.

Phillips, P.C.B. and Perron, P. (1988) Festing for a unit root in time series regression=Biometrika 75, 335-46.

Piazolo, M. (1996) Đeterminants of Indonesian economic growth, 1965-1992'. Seoul Journal of Economics 9, 269-98.

Pierce, D.A. and Haugh, L.D. (1977) Eausality in temporal systems: characterizations and a survey= Journal of Econometrics 5, 265-93.

Pomponio, X.Z. (1996) A causality analysis of growth and export performance=Atlantic Economic Journal 24, 168-76.

Prebisch, R. (1950) The Economic Development of Latin America and Its Principal Problems. New York: United Nations.

Prebisch, R. (1959) Eommercial policy in the underdeveloped countries=American Economic Review Papers \& Proceedings 49, 251-73.

Prebisch, R. (1984) Five stages in my thinking of development= In Meier, G. \& Seers, D. (eds.) Pioneers in Development. Oxford : Oxford University Press.

Quintos, C.E. (1998) Fully modified VAR inference in partially nonstationary models = Journal of the American Statistical Association 93, 783-95.

Ram, R. (1985) Æxports and economic growth: some additional evidence=Economic Development and Cultural Change 33, 415-25.

Ram, R. (1987) Æxports and economic growth in developing countries: evidence from time-series and cross-section data=Economic Development and Cultural Change 36, 51-72.

Rana, P.B. (1986) Æxports and economic growth: further evidence from Asian LDCs=Pakistan Journal of Applied Economics 5, 163-78.

Rana, P.B. (1988) Đxports, policy changes, and economic growth in developing countries after the 1973 oil shock=Journal of Development Economics 28, 261-4.

Rashid, A.I. (1995) Frade, growth, and liberalization: the Indian experience, 1977-1989'. Journal of Developing Areas 29, 355-70.

Riezman, R.G., Summers, P.M. and Whiteman, C.H. (1996) The engine of growth or its handmaiden? A time series assessment of export-led growth=Empirical Economics 21, 77113.

Roberts, D.L. and Nord, S. (1985) Eausality tests and functional form sensitivity= Applied Economics 17, 135-41. 
Romer, P.R. (1990) Are nonconvexities important for understanding growth=American Economic Review 80, 97-103.

Sachs, J.D. and Warner, A. (1995) Æconomic reform and the process of global integration= Brookings Papers on Economic Activity 1, 1-118.

Saikkonen, P. (1991) Asymptotically efficient estimation of cointegration regressions $=$ Econometric Theory 7, 1-21.

Salvatore, D. (1983) $\gtrsim$ simultaneous equations model of trade and development with dynamic policy simulations $=$ Kyklos 36, 66-90.

Salvatore, D. and Hatcher, T. (1991) ‡nward and outward oriented trade strategies=Journal of Development Studies 27, 7-25.

Sawhney, B. and DiPietro, W. (1991) Đxports, foreign debt and economic growth: evidence from cross-section data=Indian Economic Journal 38, 77-86.

Said, S.E. and Dickey, D.A. (1984) Festing for unit roots in autoregressive-moving average models of unknown order $=$ Biometrika 71, 599-607.

Schenzler, C. (1982) An empirical investigation of the relationship between growth of gross national product and exports in Chile, India and South Korea = Master $₹$ Thesis, Vanderbilt University, Nashville TN.

Schwarz, A. (1978) Estimating the dimension of a model=Annals of Statistics 6, 461-4.

Sengupta, J.K. (1993) Growth in NICs in Asia: some tests of new growth theory=Journal of Development Studies 29, 342-57.

Sengupta, J.K. and España, J.R. (1994) Exports and economic growth in Asian NICs: an econometric analysis for Korea =Applied Economics 26, 45-51.

Sephton, P. (1989) Æxport, growth and industrial development=Journal of Development Economics 31, 413-5.

Serletis, A. (1992) Đxport growth and Canadian economic development=Journal of Development Economics 38, 133-45.

Shan, J. and Sun, F. (1998a) Đxport-led growth hypothesis for Australia: an empirical reinvestigation=Applied Economics Letters 5, 423-8.

Shan, J. and Sun, F. (1998b) Đn the export-led growth hypothesis: the econometric evidence from China=Applied Economics 30, 1055-65.

Sharma, S.C. and Dhakal, D. (1994) Eausal analysis between exports and economic growth in developing countries=Applied Economics 26, 1145-57.

Sharma, S.C., Norris M. and Cheung, D.W. (1991) Exports and economic growth in industrialized countries =Applied Economics 23, 697-707.

Sheehey, E.J. (1990) Æxports and growth: a flawed framework=Journal of Development Studies 27, 111-16.

Sheehey, E.J. (1992) Æxports and growth: additional evidence=Journal of Development Studies 28, 730-4.

Siklos, P.L. and Granger, C.W.J. (1997) Regime sensitive cointegration with an application to interest rate parity =Macroeconomic Dynamics 1, 640-57.

Sims, C.A. (1972) Money, income and causality =American Economic Review 62, 540-52.

Sims, C.A. (1980) Macroeconomics and reality=Econometrica 48, 1-48.

Sims, C.A. (1981) An autoregressive index model for the U.S. 1948-1975'. In Kmenta, J. and Ramsey, J.B. (eds.) Large-Scale Macro-Econometric Models. Amsterdam: North-Holland. 
Sims, C.A. (1982) Policy analysis with econometric models=Brookings Papers on Economic Activity 1, 107-52.

Singer, H.W. (1950) The distribution of gains between investing and borrowing countries=American Economic Review Papers and Proceedings 40, 473-85.

Singer, H.W. and Gray, H. (1988) Frade policy and growth of developing countries: some new data= World Development 16, 395-403.

Södersten, B. (1964) A Study of Economic Growth and International Trade. Stockholm: Almqvist \& Wiksell.

Song, L. and Chen, T. (1995) Đn exports and economic growth: further evidence=Pacific Economic Papers, \#242.

Sprout, R.V.A. and Weaver, J.H. (1993) Exports and economic growth in a simultaneous equations model=Journal of Developing Areas 27, 289-306.

Stavrinos, V.G. (1987) The intertemporal stability of Kaldor first and second laws in the UK= Applied Economics 19, 1201-9.

Suliman, O., Mengistu, T., Lorentz, R. and Ghebreyesus, G.S. (1994) Æxports growth and industrial development: some further evidence from South Korea =Economia Internazionale 47, 84-91.

Sung-Shen, N., Biswas, B. and Tribedy, G. (1990) Eausality between exports and economic growth: an empirical study = Journal of Economic Development 15, 47-61.

Supo Alege, P. (1993) Export and growth in the Nigerian economy: a causality test=Indian Journal of Economics 73, 397-416.

Swanson, N.R. and Franses, P.H. (1998) Aonlinear econometric modelling: a selective review $=$ In Rothman, P. (ed.) Nonlinear Time Series Analysis of Economic and Financial Data. Boston: Kluwer.

Syron, R. and Walsh, B. (1968) The relation of exports and economic growth=Kyklos 21, 541-5.

Taylor, L. (1988) Varieties of Stabilization Experience: Towards Sensible Macroeconomics in the Third World. Oxford: Clarendon Press.

Teräsvirta, T. (1998) Modeling economic relationships with smooth transition regressions=In Ullah, A. and Giles, D.E.A. (eds.) Handbook of Applied Economic Statistics. New York: Marcel Dekker.

Thornton, J. (1996) Eointegration, causality and export-led growth in Mexico, 1895-1992'. Economics Letters 50, 413-6.

Thornton, J. (1997) Đxports and economic growth: evidence from nineteenth century Europe= Economics Letters 55, 235-40.

Toda, H.Y. and Phillips, P.C.B. (1993) \ector autoregression and causality=Econometrica 61, 1367-93.

Toda, H.Y. and Phillips, P.C.B. (1994) $\forall$ ector autoregression and causality: a theoretical overview and simulation study =Econometric Reviews 13, 259-85.

Toda, H.Y. and Yamamoto, T. (1995) Statistical inference in vector autoregressions with possibly integrated processes = Journal of Econometrics 66, 225-50.

Tuan, C. and Ng, L.F.-Y. (1998) Export trade, trade derivatives, and economic growth of Hong Kong: a new scenario=Journal of International Trade and Economic Development 7, 11137.

Tyler, W. (1981) Erowth and export expansion in developing countries: some empirical evidence= Journal of Development Economics 9, 121-30. 
Ukpolo, V. (1994) Æxport composition and growth of selected low-income African countries: evidence from time-series data=Applied Economics 26, 445-9.

Urquhart, M.C. (1988) Eanadian economic growth, 1870-1980'. DP \#734, Department of Economics, Queen ₹ University.

van den Berg, H. and Schmidt, J. R. (1994) Foreign trade and economic growth: time series evidence from Latin America=Journal of International Trade and Economic Development 3, 249-68.

Voivodas, C.S. (1973) Đxports, foreign capital inflow, and economic growth= Journal of International Economics 3, 337-49.

Voivodas, C.S. (1974) Đxports, foreign capital inflow, and South Korean growth=Economic Development and Cultural Change 22, 480-4.

Warne, A. (1996) Eausality in nonlinear models=Mimeo., Institute for International Economic Studies, Stockholm University.

Weiner, N. (1956) \$he theory of prediction= In Beckenback, E.F. (ed.) Modern Mathematics for Engineers (Series 1). New York: McGraw-Hill.

Williamson, R.B. (1978) The role of exports and foreign capital in Latin American economic growth=Southern Economic Journal 45, 410-20.

World Bank (1993) The East Asian Miracle: Public Policy and Economic Growth. New York: Oxford University Press.

$\mathrm{Xu}$, Z. (1996) Øn the causality between export growth and GDP growth: an empirical reinvestigation $=$ Review of International Economics 4, 172-84.

Yaghmaian, B. (1994) An empirical investigation of exports, development and growth in developing countries: challenging the neo-classical theory of export-led growth=World Development 22, 1977-95.

Yaghmaian, B. and Ghorashi, R. (1995) Export performance and economic development: an empirical analysis =The American Economist 39, 37-45.

Yamada, H. (1998) 7 note on the causality between export and productivity: an empirical reexamination=Economics Letters 61, 111-4.

Yarbrough, B.V. and Yarborough, R.M. (1994) The World Economy: Trade and Finance. Florida: The Dryden Press.

Young, A. (1991) Đearning by doing and the dynamic effects of international trade=Quarterly Journal of Economics 106, 369-405.

Zapata, H.O. and Rambaldi, A.N. (1997) Monte Carlo evidence on cointegration and causation= Oxford Bulletin of Economics and Statistics 59, 285-98.

Zellner, A. (1979) Eausality and econometrics=Carnegie-Rochester Conference Series on Public Policy 10, 9-54.

Zivot, E. and Andrews, D.W.K. (1992) Further evidence on the great crash, the oil price shock and the unit root hypothesis=Journal of Business and Economic Statistics 10, 251-70. 


\begin{tabular}{|c|c|c|c|c|}
\hline Authors & Data & Method & Other Variables & Result \\
\hline $\begin{array}{l}\text { Voivodas } \\
(1974)\end{array}$ & $\begin{array}{l}\text { annual, } \\
\text { 1955:70 }\end{array}$ & $\begin{array}{l}\text { OLS (growth of real GDP on } \\
\text { proportion of exports to output) }\end{array}$ & & $\begin{array}{l}\text { Significant } \\
\text { export/economic growth } \\
\text { relationship }\end{array}$ \\
\hline $\begin{array}{l}\text { Krueger } \\
(1978)\end{array}$ & $\begin{array}{l}\text { annual, } \\
1954: 71\end{array}$ & $\begin{array}{l}\text { OLS (log real GNP on log real } \\
\text { exports relative to average exports } \\
\text { over the entire period) }\end{array}$ & $\begin{array}{l}\text { Time trend; dummy } \\
\text { variables for trade regimes }\end{array}$ & $\begin{array}{l}\text { Significant } \\
\text { export/economic growth } \\
\text { relationship }\end{array}$ \\
\hline $\begin{array}{l}\text { Schenzler } \\
(1982)\end{array}$ & $\begin{array}{l}\text { annual, } \\
\text { 1950:79 }\end{array}$ & $\begin{array}{l}\text { OLS (real GDP growth on real } \\
\text { export growth or export share) }\end{array}$ & $\begin{array}{l}\text { Investment share; } \\
\text { government spending share; } \\
\text { foreign aid share. }\end{array}$ & $\begin{array}{l}\text { Significant } \\
\text { export/economic growth } \\
\text { relationship }\end{array}$ \\
\hline $\begin{array}{l}\text { Gupta } \\
(1985)\end{array}$ & $\begin{array}{l}\text { quarterly, } \\
1960(1): 79(4)\end{array}$ & $\begin{array}{l}\text { Bivariate Sims (real GNP \& } \\
\text { exports); prewhitened via ARIMA } \\
\text { transformations. Lags set to } 4 \text {. }\end{array}$ & & $\mathrm{BD}$ \\
\hline $\begin{array}{l}\text { Jung \& } \\
\text { Marshall } \\
(1985)\end{array}$ & $\begin{array}{l}\text { annual, } \\
\text { 1953:80 }\end{array}$ & $\begin{array}{l}\text { Bivariate Granger (real GDP } \\
\text { growth \& export growth). LVAR } \\
\text { in growth variables with constant. } \\
\text { Lags preset to } 2 .\end{array}$ & & GLE \\
\hline $\begin{array}{l}\text { Darrat } \\
(1986)\end{array}$ & $\begin{array}{l}\text { annual, } \\
\text { 1960:82 }\end{array}$ & $\begin{array}{l}\text { Bivariate Granger (LVAR in } \% \\
\text { change in real GDP \& exports). } \\
\text { Lags set to } 2 .\end{array}$ & & $\mathrm{NC}$ \\
\hline $\begin{array}{l}\text { Chow } \\
(1987)\end{array}$ & $\begin{array}{l}\text { annual, } \\
\text { 1960:80 }\end{array}$ & $\begin{array}{l}\text { Bivariate Sims (data prefiltered by } \\
(1-0.75 \mathrm{~L})^{2}, \mathrm{LVAR} \text { in transformed } \\
\text { real manufactured exports and } \\
\text { output). Lags set to } 3 \text {. }\end{array}$ & & ELG \\
\hline $\begin{array}{l}\text { Darrat } \\
(1987)\end{array}$ & $\begin{array}{l}\text { annual, } \\
1955: 82\end{array}$ & $\begin{array}{l}\text { Real GDP growth on lagged \& } \\
\text { current export growth; real export } \\
\text { growth on lagged \& current GDP } \\
\text { growth. Lags preset. }\end{array}$ & & ELG \\
\hline $\begin{array}{l}\text { Hsiao } \\
(1987)\end{array}$ & $\begin{array}{l}\text { annual, } \\
\text { 1960:82 }\end{array}$ & $\begin{array}{l}\text { Bivariate Sims \& Granger (logs; } \\
\text { real GDP \& exports). DVAR with } \\
\text { constant. Lags set to } 3 \text {. }\end{array}$ & & $\begin{array}{l}\text { Sims - BD. } \\
\text { Granger - NC }\end{array}$ \\
\hline $\begin{array}{l}\text { Ram } \\
(1987)\end{array}$ & $\begin{array}{l}\text { annual, } \\
\text { 1960:82 }\end{array}$ & $\begin{array}{l}\text { OLS \& AUTO (real GDP growth } \\
\text { on real export growth or \% share } \\
\text { of changes in exports in GDP). }\end{array}$ & $\begin{array}{l}\text { Population growth; real } \\
\text { investment as share of } \\
\text { output; dummy variable for } \\
1973 \text { oil crisis. }\end{array}$ & $\begin{array}{l}\text { Significant } \\
\text { export/economic growth } \\
\text { effect. }\end{array}$ \\
\hline $\begin{array}{l}\text { Sung-Shen } \\
\text { et al. } \\
\text { (1990) }\end{array}$ & $\begin{array}{l}\text { quarterly, } \\
\text { seasonally } \\
\text { adjusted, } \\
\text { 1960(1):84(4) }\end{array}$ & $\begin{array}{l}\text { Bivariate Granger (logs; real GDP } \\
\text { \& exports). DVAR with constant. } \\
\text { DF for unit root. Lags by FPE. }\end{array}$ & & $\mathrm{BD}$ \\
\hline $\begin{array}{l}\text { Bahmani- } \\
\text { Oskooee et } \\
\text { al. }(1991)\end{array}$ & $\begin{array}{l}\text { annual, } \\
\text { 1963:87 }\end{array}$ & $\begin{array}{l}\text { Bivariate Granger (real GDP \& } \\
\text { export growth). LVAR in } \Delta \text { growth } \\
\text { variables (i.e. D }{ }^{2} \text { VAR) with } \\
\text { constant. Lags by FPE. }\end{array}$ & & $\mathrm{BD}$ \\
\hline
\end{tabular}




\begin{tabular}{|c|c|c|c|c|}
\hline $\begin{array}{l}\text { Salvatore \& } \\
\text { Hatcher } \\
(1991)\end{array}$ & $\begin{array}{l}\text { annual, } \\
\text { 1960:85 }\end{array}$ & $\begin{array}{l}\text { OLS \& AUTO (real GDP and } \\
\text { export growth). }\end{array}$ & $\begin{array}{l}\text { Gross fixed capital } \\
\text { formation as \% of GDP; real } \\
\text { industrial production } \\
\text { growth. }\end{array}$ & $\begin{array}{l}\text { No significant } \\
\text { export/economic growth } \\
\text { effect. }\end{array}$ \\
\hline $\begin{array}{l}\text { Hutchison } \\
\text { \& Singh } \\
(1992)\end{array}$ & $\begin{array}{l}\text { annual, } \\
1956: 84\end{array}$ & $\begin{array}{l}\text { Bivariate \& trivariate Granger } \\
\text { (logs; real GDP, non-export GDP } \\
\text { \& exports). DVAR with no } \\
\text { deterministic terms. Lags preset to } \\
2 .\end{array}$ & Real investment. & $\begin{array}{l}\text { NC irrespective of } \\
\text { definition of economic } \\
\text { growth. }\end{array}$ \\
\hline $\begin{array}{l}\text { Bahmani- } \\
\text { Oskooee \& } \\
\text { Alse (1993) }\end{array}$ & $\begin{array}{l}\text { quarterly, } \\
1973(1): 88(4)\end{array}$ & $\begin{array}{l}\text { Bivariate Granger (logs; real GDP } \\
\text { \& exports). ADF for unit roots; } \\
\text { CRDW \& EG-ADF for } \\
\text { cointegation with constant - yes, so } \\
\text { ECM with constant. Lags by } \\
\text { specific to general. }\end{array}$ & & $\mathrm{BD}$ \\
\hline $\begin{array}{l}\text { Dodaro } \\
(1993)\end{array}$ & $\begin{array}{l}\text { annual, } \\
1967: 86\end{array}$ & $\begin{array}{l}\text { Bivariate Granger (growth of real } \\
\text { GDP \& exports). LVAR in growth } \\
\text { variables with constant. Lags } \\
\text { preset to } 2 .\end{array}$ & & $\mathrm{NC}$ \\
\hline $\begin{array}{l}\text { Kugler \& } \\
\text { Dridi } \\
\text { (1993) }\end{array}$ & $\begin{array}{l}\text { annual, } \\
\text { 1960:89 }\end{array}$ & $\begin{array}{l}\text { 4-variables with conclusions based } \\
\text { solely on cointegration outcomes. } \\
\text { Logs; real GDP \& exports. ADF } \\
\text { for unit roots; JJML (Case 1) for } \\
\text { cointegration with lags via AIC - } \\
\text { yes. }\end{array}$ & $\begin{array}{l}\text { Total private consumption } \\
\text { expenditures; business-fixed } \\
\text { investment. }\end{array}$ & $\begin{array}{l}\text { ELG due to } \\
\text { cointegration outcome. }\end{array}$ \\
\hline $\begin{array}{l}\text { Sengupta } \\
(1993)\end{array}$ & $\begin{array}{l}\text { annual, } \\
1967: 86\end{array}$ & $\begin{array}{l}\text { OLS (GDP growth \& } \% \text { share of } \\
\text { changes in exports in GDP; } \Delta \text { real } \\
\text { GDP \& exports). }\end{array}$ & $\begin{array}{l}\text { Real investment; } \\
\text { employment. }\end{array}$ & $\begin{array}{l}\text { Significant } \\
\text { export/economic growth } \\
\text { effect. }\end{array}$ \\
\hline $\begin{array}{l}\text { Dutt \& } \\
\text { Ghosh } \\
(1994)\end{array}$ & $\begin{array}{l}\text { annual, } \\
\text { 1953:91. }\end{array}$ & $\begin{array}{l}\text { Bivariate with conclusions based } \\
\text { solely on cointegration outcomes. } \\
\text { Logs; real GDP \& exports. ADF } \\
\text { for unit roots; PO for cointegration } \\
\text { with \& without constant \& trend - } \\
\text { no. }\end{array}$ & & $\begin{array}{l}\mathrm{NC} \text { based on } \\
\text { cointegration outcome. }\end{array}$ \\
\hline $\begin{array}{l}\text { Greenaway } \\
\text { \& Sapsford } \\
(1994 a)\end{array}$ & $\begin{array}{l}\text { annual, } \\
1964: 85\end{array}$ & $\begin{array}{l}\text { OLS (real GDP per capita growth } \\
\& \text { growth of exports. Repeated } \\
\text { with (weighted) growth of non- } \\
\text { export GDP. Also with export } \\
\text { variable expressed as \% share of } \\
\text { changes in exports in GDP). ADF } \\
\text { for unit roots. }\end{array}$ & $\begin{array}{l}\text { Share of investment in } \\
\text { output; growth of the } \\
\text { workforce. }\end{array}$ & $\begin{array}{l}\text { No significant } \\
\text { export/economic growth } \\
\text { effect irrespective of } \\
\text { specification. }\end{array}$ \\
\hline $\begin{array}{l}\text { Greenaway } \\
\text { \& Sapsford } \\
(1994 b)\end{array}$ & $\begin{array}{l}\text { annual, } \\
1957: 85\end{array}$ & $\begin{array}{l}\text { OLS (real GDP per capita growth } \\
\& \text { growth of export share of GDP). } \\
\text { ADF for unit roots. }\end{array}$ & $\begin{array}{l}\text { Share of investment in } \\
\text { output; growth of the } \\
\text { workforce. }\end{array}$ & $\begin{array}{l}\text { No significant } \\
\text { export/economic growth } \\
\text { effect. }\end{array}$ \\
\hline $\begin{array}{l}\text { Sengupta \& } \\
\text { España } \\
(1994)\end{array}$ & $\begin{array}{l}\text { annual, } \\
\text { 1960:86 }\end{array}$ & $\begin{array}{l}\text { OLS ( } \Delta \text { real GDP \& } \Delta \text { real exports). } \\
\text { CRDW \& EG-ADF for } \\
\text { cointegration - yes. }\end{array}$ & 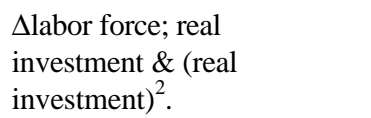 & $\begin{array}{l}\text { Significant } \\
\text { export/economic growth } \\
\text { effect. }\end{array}$ \\
\hline
\end{tabular}




\begin{tabular}{|c|c|c|c|c|}
\hline $\begin{array}{l}\text { Sharma \& } \\
\text { Dhakal } \\
(1994)\end{array}$ & $\begin{array}{l}\text { annual, } \\
1963: 88\end{array}$ & $\begin{array}{l}\text { 4-variable Granger (logs; real GDP } \\
\& \text { exports). PP for unit roots; no } \\
\text { cointegration test. DVAR with } \\
\text { constant. Lags by FPE. }\end{array}$ & $\begin{array}{l}\text { Population; real world } \\
\text { output; real exchange rate; } \\
\text { real gross fixed capital } \\
\text { formation. }\end{array}$ & $\mathrm{NC}$ \\
\hline $\begin{array}{l}\text { Suliman et } \\
\text { al. (1994) }\end{array}$ & $\begin{array}{l}\text { annual, } \\
1967: 89 .\end{array}$ & $\begin{array}{l}\text { 4-variable Granger (logs; real GDP } \\
\text { \& exports). ADF for unit roots; no } \\
\text { cointegration test. DVAR with } \\
\text { constant. Lags by FPE. }\end{array}$ & $\begin{array}{l}\text { Extent of development } \\
\text { expressed as the ratio of } \\
\text { currency outside bank to } \\
\text { IMF money supply data; } \\
\text { import competing } \\
\text { (manufacturing) output. }\end{array}$ & $\mathrm{BD}$ \\
\hline $\begin{array}{l}\text { Amirkhal- } \\
\text { khali \& Dar } \\
\text { (1995) }\end{array}$ & $\begin{array}{l}\text { annual, } \\
\text { 1961:90 }\end{array}$ & $\begin{array}{l}\text { OLS (real GDP growth on real } \\
\text { export growth). }\end{array}$ & $\begin{array}{l}\text { Real investment to output } \\
\text { share; population growth. }\end{array}$ & $\begin{array}{l}\text { Significant } \\
\text { export/economic growth } \\
\text { effect. }\end{array}$ \\
\hline $\begin{array}{l}\text { Arnade \& } \\
\text { Vasavada } \\
(1995)\end{array}$ & $\begin{array}{l}\text { annual, } \\
1961: 87 .\end{array}$ & $\begin{array}{l}\text { Trivariate Granger (real } \\
\text { agricultural output \& agricultural } \\
\text { exports). ADF for unit roots; JJML } \\
\text { (Case } 1 * \text { ) for cointegration - yes, } \\
\text { so ECM with no deterministic } \\
\text { terms. Lags preset to } 3 \text {. }\end{array}$ & $\begin{array}{l}\text { Terms of trade (unit export } \\
\text { value/unit import value). }\end{array}$ & GLE \\
\hline $\begin{array}{l}\text { Holman \& } \\
\text { Graves } \\
(1995)\end{array}$ & $\begin{array}{l}\text { annual, } \\
\text { 1953:90. }\end{array}$ & $\begin{array}{l}\text { Bivariate Granger \& Sims (logs; } \\
\text { real GNP \& exports). DF for unit } \\
\text { roots; EG-ADF for cointegration } \\
\text { with constant - no, so DVAR with } \\
\text { constant. Lags by FPE. }\end{array}$ & & $\mathrm{BD}$ \\
\hline Jin (1995) & $\begin{array}{l}\text { quarterly, } \\
\text { seasonally } \\
\text { adjusted, } \\
\text { 1973(1):93(2) }\end{array}$ & $\begin{array}{l}\text { 5-variable Granger - FEVDs \& } \\
\text { IRFs; } 20 \text { quarter horizon; logs; real } \\
\text { GDP \& exports). ADF for unit } \\
\text { roots; EG-ADF for cointegration } \\
\text { with constant \& trend - no, so } \\
\text { DVAR with constant. Lags set to } \\
12 .\end{array}$ & $\begin{array}{l}\text { Industrial production index; } \\
\text { world commodity price level } \\
\text { for exports; real exchange } \\
\text { rates. }\end{array}$ & $\mathrm{BD}$ \\
\hline $\begin{array}{l}\text { Jin \& Yu } \\
(1995)\end{array}$ & $\begin{array}{l}\text { quarterly, } \\
\text { seasonally } \\
\text { adjusted, } \\
1960(1): 87(4)\end{array}$ & $\begin{array}{l}\text { Bivariate Granger (logs; real GDP } \\
\text { \& exports). DVAR with constant. } \\
\text { Lags by FPE. }\end{array}$ & & $\mathrm{BD}$ \\
\hline $\begin{array}{l}\text { Dutt \& } \\
\text { Ghosh } \\
(1996)\end{array}$ & $\begin{array}{l}\text { annual, } \\
\text { 1953:91 }\end{array}$ & $\begin{array}{l}\text { Bivariate Granger (logs; real GDP } \\
\& \text { exports). DF, PP and KPSS for } \\
\text { unit roots; EG-ADF \& PO for } \\
\text { cointegration with constant \& } \\
\text { trend - yes, so ECM with no } \\
\text { deterministic terms. Lags by SC. }\end{array}$ & & $\mathrm{NC}$ \\
\hline
\end{tabular}




\begin{tabular}{|c|c|c|c|c|}
\hline $\begin{array}{l}\text { Pomponio } \\
\text { (1996) }\end{array}$ & $\begin{array}{l}\text { annual, } \\
\text { 1965:85 }\end{array}$ & $\begin{array}{l}\text { Bivariate \& trivariate Granger } \\
\text { (nominal manufactured output \& } \\
\text { exports). Trivariate case is tested } \\
\text { as (investment+export) causes } \\
\text { output (IELG) and (investment+ } \\
\text { output) causes exports (IGLE). } \\
\text { Unit root \& cointegration tests } \\
\text { undertaken but not specified. } \\
\text { LVAR in growth variables if } \\
\text { integrated but not cointegrated; } \\
\text { LVAR in levels if cointegrated. } \\
\text { Lags set to } 2 .\end{array}$ & Investment. & $\begin{array}{l}\text { Bivariate - NC. } \\
\text { Trivariate - BD. }\end{array}$ \\
\hline $\begin{array}{l}\text { Riezman et } \\
\text { al. (1996) }\end{array}$ & $\begin{array}{l}\text { annual, } \\
\text { 1950:90. }\end{array}$ & $\begin{array}{l}\text { Bivariate \& trivariate Granger \& } \\
\text { FEVDs - } 5 \text { \& } 16 \text { year horizons } \\
\text { with } 2 \text { orderings tried. Geweke } \\
\text { (1984) (1984b) CLFs. Also 5- } \\
\text { variable CLF tried. LVAR in GDP } \\
\text { \& export growth in current } \\
\text { international dollars with no } \\
\text { deterministic terms. Lags not } \\
\text { specified. }\end{array}$ & $\begin{array}{l}\text { Real import growth. For } 5- \\
\text { variable, also primary school } \\
\text { enrolment as \% of primary } \\
\text { school age children; total } \\
\text { investment/output. }\end{array}$ & $\begin{array}{l}\text { GLE from bivariate } \\
\text { analyses. } \\
\text { ELG from trivariate } \\
\text { restrictions test and } \\
\text { FEVDs. } \\
\text { CLF suggest GLE for } \\
\text { the trivariate system but } \\
\text { NC for the 5-variable } \\
\text { system. }\end{array}$ \\
\hline Xu (1996) & $\begin{array}{l}\text { annual, } \\
\text { 1963:89 }\end{array}$ & $\begin{array}{l}\text { Bivariate Granger (logs; real GDP } \\
\text { \& exports). ADF for unit roots; } \\
\text { EG-ADF with no constant for } \\
\text { cointegration - yes, so } \\
\text { ECM with constant. Lags by FPE. }\end{array}$ & & ELG \\
\hline $\begin{array}{l}\text { Dhananja- } \\
\text { yan \& Devi } \\
(1997)\end{array}$ & $\begin{array}{l}\text { annual, } \\
\text { 1981:94 }\end{array}$ & $\begin{array}{l}\text { OLS (logs; real GNP growth, total } \\
\text { exports, manufactured commodity } \\
\text { exports, manufactured commodity } \\
\text { exports as } \% \text { of total exports). }\end{array}$ & Gross domestic investment. & $\begin{array}{l}\text { Significant } \\
\text { export/economic growth } \\
\text { effect. }\end{array}$ \\
\hline $\begin{array}{l}\text { Ghatak } \\
(1998)\end{array}$ & $\begin{array}{l}\text { annual, } \\
\text { 1950:94. }\end{array}$ & $\begin{array}{l}\text { 7-variable Granger (logs; real per } \\
\text { capita GDP \& exports). ADF for } \\
\text { unit roots; EG-ADF for } \\
\text { cointegration with constant and } \\
\text { trend - yes, so ECM with constant. } \\
\text { Also LVAR, BVARs with } \\
\text { constant. Lags by FPE. }\end{array}$ & $\begin{array}{l}\text { Real per capita investment; } \\
\text { government spending; } \\
\text { money supply; interest rate; } \\
\text { exchange rate. }\end{array}$ & $\begin{array}{l}\text { ELG from BVAR and } \\
\text { ECM but not from } \\
\text { LVAR. }\end{array}$ \\
\hline $\begin{array}{l}\text { Islam } \\
\text { (1998) }\end{array}$ & $\begin{array}{l}\text { annual, } \\
1967: 91\end{array}$ & $\begin{array}{l}\text { Bivariate \& 5-variable Granger } \\
\text { (proportion of export earnings in } \\
\text { GDP; change in share of non- } \\
\text { export component in GDP; real } \\
\text { GDP). ADF for unit roots; JJML } \\
\text { (Case 1) for cointegration - no, so } \\
\text { DVAR with constant. Lags by } \\
\text { FPE. }\end{array}$ & $\begin{array}{l}\text { Share of non-defence } \\
\text { expenditures in GDP; } \\
\text { imports as share of GDP; } \\
\text { total investment share of } \\
\text { GDP. }\end{array}$ & $\begin{array}{l}\text { NC from bivariate; ELG } \\
\text { from multivariate. }\end{array}$ \\
\hline
\end{tabular}




\begin{tabular}{|c|c|c|c|c|}
\hline Authors & Data & Method & Other Variables & Result \\
\hline $\begin{array}{l}\text { Blumenthal } \\
\text { (1974) }\end{array}$ & $\begin{array}{l}\text { annual, } \\
\text { quarterly } \\
1953: 67\end{array}$ & $\begin{array}{l}\text { OLS (growth of real exports \& } \\
\text { growth of real GDP) }\end{array}$ & & $\begin{array}{l}\text { No significant } \\
\text { export/economic growth } \\
\text { effect. }\end{array}$ \\
\hline $\begin{array}{l}\text { Grabowski } \\
(1988)\end{array}$ & $\begin{array}{l}\text { annual, } \\
1885: 1940\end{array}$ & $\begin{array}{l}\text { OLS (growth of real GNE on } \\
\text { exports or exports as share of } \\
\text { GNE, or growth of per capita } \\
\text { GNE \& exports). Also } 3 \\
\text { equation SEM. }\end{array}$ & $\begin{array}{l}\text { Real gross capital formation as } \\
\text { a share of GNE or growth of } \\
\text { gross capital formation per } \\
\text { capita; labor force growth; } \\
\text { agricultural land growth; } \\
\Delta \text { growth of GNE; volume of } \\
\text { world trade; time trend. }\end{array}$ & $\begin{array}{l}\text { Significant } \\
\text { export/economic growth } \\
\text { effect. }\end{array}$ \\
\hline $\begin{array}{l}\text { Grabowski et } \\
\text { al. (1990) }\end{array}$ & $\begin{array}{l}\text { annual, } \\
\text { 1885:1939 \& } \\
\text { 1952:80. }\end{array}$ & $\begin{array}{l}\text { 5-variable Granger (logs; real } \\
\text { GDP \& exports). DVAR with } \\
\text { constant. Lags by FPE. }\end{array}$ & $\begin{array}{l}\text { Real gross capital stock; labor } \\
\text { force; agricultural productivity. }\end{array}$ & $\begin{array}{l}\text { No ELG for 1885:1939; } \\
\text { ELG for 1952:80. }\end{array}$ \\
\hline $\begin{array}{l}\text { Sung-Shen } \\
\text { et al. (1990) }\end{array}$ & $\begin{array}{l}\text { quarterly, } \\
\text { seasonally } \\
\text { adjusted, } \\
1957(1): 87(1)\end{array}$ & $\begin{array}{l}\text { Bivariate Granger (logs; real } \\
\text { GDP \& exports). DVAR with } \\
\text { constant. DF for unit root. Lags } \\
\text { by FPE. }\end{array}$ & & $\mathrm{BD}$ \\
\hline $\begin{array}{l}\text { Afxentiou \& } \\
\text { Serletis } \\
(1991)\end{array}$ & $\begin{array}{l}\text { annual, } \\
1950: 85 .\end{array}$ & $\begin{array}{l}\text { Bivariate Granger (logs; real } \\
\text { GNP \& exports). PP for unit } \\
\text { root \& cointegration - yes, so } \\
\text { LVAR with no deterministic } \\
\text { terms. Lags by SC. }\end{array}$ & & GLE \\
\hline $\begin{array}{l}\text { Kugler } \\
(1991)\end{array}$ & $\begin{array}{l}\text { quarterly, } \\
\text { seasonally } \\
\text { adjusted, } \\
\text { 1970:87. }\end{array}$ & $\begin{array}{l}\text { 4-variable Granger (logs; real } \\
\text { GDP \& exports). ADF for unit } \\
\text { root; JJML (AIC, Case 1) for } \\
\text { cointegration - no. }\end{array}$ & $\begin{array}{l}\text { Total real private consumption; } \\
\text { real gross fixed capital business } \\
\text { investment. }\end{array}$ & $\begin{array}{l}\text { Results based on } \\
\text { cointegration outcome; } \\
\text { so concludes no ELG. }\end{array}$ \\
\hline $\begin{array}{l}\text { Sharma et al. } \\
\text { (1991) }\end{array}$ & $\begin{array}{l}\text { quarterly, } \\
1960(1): 87(2) .\end{array}$ & $\begin{array}{l}\text { 4-variable Granger - FEVDs; } 4 \\
\text { orderings; } 8 \text { \& } 20 \text { quarter } \\
\text { horizons; (logs; real GNP \& } \\
\text { exports). DVAR with constant. } \\
\text { Lags by FPE. }\end{array}$ & Labor; real capital formation. & ELG \\
\hline $\begin{array}{l}\text { Marin } \\
(1992)\end{array}$ & $\begin{array}{l}\text { quarterly, } \\
1960(1): 87(2)\end{array}$ & $\begin{array}{l}\text { 4-variable Granger (logs; } \\
\text { manufacturing output per } \\
\text { employee \& real exports of } \\
\text { manufacturing goods). DF \& } \\
\text { ADF for unit roots; CRDW \& } \\
\text { EG-ADF for cointegration with } \\
\text { no deterministic terms -yes, so } \\
\text { ECM with constant. Lags by } \\
\text { BIC for own; set to } 4 \text { for other } \\
\text { variables. }\end{array}$ & $\begin{array}{l}\text { Terms of trade (export unit } \\
\text { value/import unit value for } \\
\text { manufacturing goods); real } \\
\text { OECD output. }\end{array}$ & $\mathrm{BD}$ \\
\hline $\begin{array}{l}\text { Ghartey } \\
\text { (1993) }\end{array}$ & $\begin{array}{l}\text { quarterly, } \\
\text { seasonally } \\
\text { adjusted, } \\
1955(1): 91(2)\end{array}$ & $\begin{array}{l}\text { 4-variable Granger (logs; real } \\
\text { GNP \& exports). DF \& ADF } \\
\text { for unit roots. No cointegration } \\
\text { test. D }{ }^{2} \text { VAR with no } \\
\text { deterministic terms. Lags by } \\
\text { FPE \& SC. }\end{array}$ & Capital stock; terms of trade. & $\mathrm{BD}$ \\
\hline
\end{tabular}




\begin{tabular}{|c|c|c|c|c|}
\hline $\begin{array}{l}\text { Sengupta } \\
(1993)\end{array}$ & $\begin{array}{l}\text { annual, } \\
1961: 87\end{array}$ & $\begin{array}{l}\text { OLS (GDP growth \& \% share } \\
\text { of changes in exports in GDP; } \\
\Delta \text { real GDP \& exports). }\end{array}$ & Real investment; employment. & $\begin{array}{l}\text { No significant } \\
\text { export/economic growth } \\
\text { effect but yes if } \\
\text { definition of export } \\
\text { variable changes. }\end{array}$ \\
\hline $\begin{array}{l}\text { Dutt \& } \\
\text { Ghosh } \\
(1994)\end{array}$ & $\begin{array}{l}\text { annual, } \\
\text { 1953:91. }\end{array}$ & $\begin{array}{l}\text { Bivariate with conclusions } \\
\text { based solely on cointegration } \\
\text { outcomes. Logs; real GDP \& } \\
\text { exports. ADF for unit roots; PO } \\
\text { for cointegration with \& without } \\
\text { constant \& trend - no. }\end{array}$ & & $\begin{array}{l}\text { NC based on } \\
\text { cointegration outcome. }\end{array}$ \\
\hline $\begin{array}{l}\text { Sengupta \& } \\
\text { España } \\
(1994)\end{array}$ & $\begin{array}{l}\text { annual, } \\
\text { 1960:85 }\end{array}$ & $\begin{array}{l}\text { OLS ( } \Delta \text { real GDP \& } \Delta \text { real } \\
\text { exports). }\end{array}$ & $\begin{array}{l}\Delta \text { labor force; real investment } \\
\& \text { (real investment })^{2} .\end{array}$ & $\begin{array}{l}\text { No significant } \\
\text { export/economic growth } \\
\text { effect. }\end{array}$ \\
\hline $\begin{array}{l}\text { Arnade \& } \\
\text { Vasavada } \\
(1995)\end{array}$ & $\begin{array}{l}\text { annual, } \\
1961: 87 .\end{array}$ & $\begin{array}{l}\text { Trivariate Granger (real } \\
\text { agricultural output \& } \\
\text { agricultural exports). ADF for } \\
\text { unit roots; JJML (Case } 1^{*} \text { ) for } \\
\text { cointegration - yes, so ECM } \\
\text { with no deterministic terms. } \\
\text { Lags preset to } 3 \text {. }\end{array}$ & $\begin{array}{l}\text { Terms of trade (unit export } \\
\text { value/unit import value). }\end{array}$ & $\mathrm{NC}$ \\
\hline $\begin{array}{l}\text { Jin \& Yu } \\
(1995)\end{array}$ & $\begin{array}{l}\text { quarterly, } \\
\text { seasonally } \\
\text { adjusted, } \\
\text { 1960(1):87(4) }\end{array}$ & $\begin{array}{l}\text { Bivariate Granger (logs; real } \\
\text { GNP \& exports). DVAR with } \\
\text { constant. Lags by FPE. }\end{array}$ & & $\mathrm{BD}$ \\
\hline $\begin{array}{l}\text { Boltho } \\
(1996)\end{array}$ & $\begin{array}{l}\text { annual, } \\
\text { 1913:37; } \\
\text { 1952:73; } \\
\text { 1973:90. }\end{array}$ & $\begin{array}{l}\text { Bivariate Granger. LVAR in } \\
\text { growth of real GDP \& exports. } \\
\text { Also some sectors. }\end{array}$ & & $\begin{array}{l}\text { Some evidence of GLE } \\
\text { for total exports; BD for } \\
\text { cars. }\end{array}$ \\
\hline $\begin{array}{l}\text { Dutt \& } \\
\text { Ghosh } \\
(1996)\end{array}$ & $\begin{array}{l}\text { annual, } \\
\text { 1953:91 }\end{array}$ & $\begin{array}{l}\text { Bivariate Granger (logs; real } \\
\text { GDP \& exports). DF, PP and } \\
\text { KPSS for unit roots; EG-ADF \& } \\
\text { PO for cointegration with } \\
\text { constant \& trend - no, so no } \\
\text { further work undertaken. }\end{array}$ & & $\begin{array}{l}\text { NC because } \\
\text { noncointegrated. }\end{array}$ \\
\hline $\begin{array}{l}\text { Pomponio } \\
(1996)\end{array}$ & $\begin{array}{l}\text { annual, } \\
1965: 85\end{array}$ & $\begin{array}{l}\text { Bivariate \& trivariate Granger } \\
\text { (nominal manufactured output } \\
\& \text { exports). Trivariate case is } \\
\text { tested as (investment+export) } \\
\text { causes output (IELG) and } \\
\text { (investment+ output) causes } \\
\text { exports (IGLE). Unit root \& } \\
\text { cointegration tests undertaken } \\
\text { but not specified. LVAR in } \\
\text { growth variables if integrated } \\
\text { but not cointegrated; LVAR in } \\
\text { levels if cointegrated; with } \\
\text { constant. Lags set to } 2 .\end{array}$ & Investment. & $\begin{array}{l}\text { Bivariate - NC. } \\
\text { Trivariate - IELG. }\end{array}$ \\
\hline
\end{tabular}




\begin{tabular}{|c|c|c|c|c|}
\hline $\begin{array}{l}\text { Riezman et } \\
\text { al. (1996) }\end{array}$ & $\begin{array}{l}\text { annual, } \\
1950: 90 .\end{array}$ & $\begin{array}{l}\text { Bivariate \& trivariate Granger \& } \\
\text { FEVDs - } 5 \text { \& } 16 \text { year horizons } \\
\text { with } 2 \text { orderings tried. Geweke } \\
\text { (1984) CLFs. Also 5-variable } \\
\text { CLF tried. LVAR in GDP \& } \\
\text { export growth in current } \\
\text { international dollars with no } \\
\text { deterministic terms. Lags not } \\
\text { specified. }\end{array}$ & $\begin{array}{l}\text { Real import growth. For } 5- \\
\text { variable, also primary school } \\
\text { enrolment as \% of primary } \\
\text { school age children; total } \\
\text { investment/output. }\end{array}$ & $\begin{array}{l}\text { GLE from bivariate } \\
\text { analyses and from } \\
\text { trivariate restrictions test } \\
\text { \& FEVDs. } \\
\text { CLF suggest GLE } \\
\text { irrespective of included } \\
\text { variables. }\end{array}$ \\
\hline Islam (1998) & $\begin{array}{l}\text { annual, } \\
\text { 1967:91 }\end{array}$ & $\begin{array}{l}\text { Bivariate \& 5-variable Granger } \\
\text { (proportion of export earnings in } \\
\text { GDP; change in share of non- } \\
\text { export component in GDP; real } \\
\text { GDP). ADF for unit roots; } \\
\text { JJML (Case 1) for cointegration } \\
\text { - no, so DVAR with constant. } \\
\text { Lags by FPE. }\end{array}$ & $\begin{array}{l}\text { Share of non-defence } \\
\text { expenditures in GDP; imports } \\
\text { as share of GDP; total } \\
\text { investment share of GDP. }\end{array}$ & $\begin{array}{l}\text { ELG from bivariate \& } \\
\text { multivariate. }\end{array}$ \\
\hline $\begin{array}{l}\text { Yamada } \\
(1998)\end{array}$ & $\begin{array}{l}\text { quarterly, } \\
\text { seasonally } \\
\text { adjusted, } \\
\text { 1975(1):97(2). }\end{array}$ & $\begin{array}{l}\text { 4-variable Granger (real GDP } \\
\text { per employee;real exports). } \\
\text { OVER LVAR with constant. } \\
\text { Lags by HQ and AIC. }\end{array}$ & $\begin{array}{l}\text { Terms of trade (export price } \\
\text { deflator/import price deflator); } \\
\text { real GDP of OECD countries }\end{array}$ & $\begin{array}{l}\text { Only examined for ELG. } \\
\text { None detected for } \\
\text { Japan. }\end{array}$ \\
\hline
\end{tabular}


Table 3 Canada : Wald Granger noncausality p-values (Case $1^{*}$ )

\begin{tabular}{|c|c|c|c|c|c|c|c|c|c|}
\hline & \multicolumn{3}{|c|}{ BIVARIATE MODEL } & \multicolumn{5}{c|}{ TRIVARIATE MODEL } \\
\cline { 2 - 10 } & OVER $^{\mathrm{a}}$ & JJML $^{\mathrm{b}}$ & $\mathrm{MLS}^{\mathrm{c}}$ & EG-ADF $^{\mathrm{d}}$ & OVER $^{\mathrm{a}}$ & $\mathrm{TP}^{\mathrm{e}}$ & JJML $^{\mathrm{f}}$ & MLS $^{\mathrm{g}}$ & EG-ADF $^{\mathrm{h}}$ \\
\hline $\exp \nrightarrow$ gdp & 0.659 & $<0.001$ & 0.551 & 0.714 & 0.604 & 0.005 & 0.005 & 0.549 & 0.691 \\
\hline gdp $\nrightarrow \exp$ & 0.283 & 0.001 & 0.292 & 0.001 & 0.198 & $<0.001$ & $<0.001$ & 0.211 & $<0.001$ \\
\hline
\end{tabular}

1. One additional lag is included in the system based on our prior belief that the variables are integrated of order one.

2. The sample values of the maximum eigenvalue statistic are 19.156 and 10.758 for testing $\mathrm{H}_{01}$ : $\mathrm{r}=0$ vs. $\mathrm{H}_{\mathrm{a} 1}: \mathrm{r}=1$ and $\mathrm{H}_{02}: \mathrm{r}=1$ vs. $\mathrm{H}_{\mathrm{a} 2}: \mathrm{r}=2$, respectively. Estimated asymptotic p-values are 0.001 and 0.270 respectively (MacKinnon et al., 1996). We reject $\mathrm{H}_{01}$ and support $\mathrm{H}_{02}$ suggesting one cointegrating vector. Noncausality testing is via an $\operatorname{ECM}(3)$.

3. The observed value of the test statistic is 0.704 which can be compared to a $10 \%$ critical value of approximately 0.097 (McCabe et al., 1997): we reject the null and support noncointegration. A DVAR(3) model, with unrestricted constant, is used to test for noncausality.

4. Eight augmentation terms are included as chosen via general to specific testing. The observed test statistic value of -3.846 has an estimated p-value of 0.015 (MacKinnon, 1994). An $\operatorname{ECM}(3)$ is then used to test for noncausality with the error correction term formed from the residuals from the static cointegrating regression.

5. From $\mathrm{f}$. we have $\mathrm{r}^{*}=2$. For both causality tests we reject $\mathrm{H}_{1}$, so the $\mathrm{p}$-value in the table refers to that for testing $\mathrm{H}_{2}$ : both hypotheses are defined in footnote 21 .

6. The sample values of the maximum eigenvalue statistic for testing $\mathrm{H}_{01}: r=0$ vs. $\mathrm{H}_{\mathrm{a} 1}: \mathrm{r}=1, \mathrm{H}_{02}$ : $\mathrm{r}=1$ vs. $\mathrm{H}_{\mathrm{a} 2}: \mathrm{r}=2$ and $\mathrm{H}_{02}: \mathrm{r}=2$ vs. $\mathrm{H}_{\mathrm{a} 2}: \mathrm{r}=3$ are $24.381,16.240$ and 12.395 with estimated asymptotic p-values of $0.0004,0.044$ and 0.616 respectively (MacKinnon et al., 1996). These results suggest two cointegrating vectors: we impose this and use the resulting ML estimates to convert back to the levels autoregressive model to undertake the noncausality tests.

7. Observed value of the test statistic is 0.594 compared to an approximate $10 \%$ critical value of 0.081 (McCabe et al., 1997). A DVAR(3) model, with unrestricted constant, is used to test for noncausality.

8. Eight augmentation terms (from a general to specific testing strategy) are included. The observed value of the test statistic is -3.749 which has an estimated p-value of 0.020 using MacKinnon (1994). The noncausality tests are undertaken via an $\operatorname{ECM}(3)$ with the residuals from the static cointegrating regression as the error correction terms. 
Table 4 Portugal : Wald Granger noncausality p-values (Case $1^{*}$ )

\begin{tabular}{|c|c|c|c|c|}
\hline & OVER $^{\mathrm{a}}$ & $\mathrm{JJML}^{\mathrm{b}}$ & MLS & EG-ADF $^{\mathrm{d}}$ \\
\hline exp $\nrightarrow$ gdp & 0.191 & 0.001 & 0.253 & 0.192 \\
\hline gdp $\rightarrow$ exp & 0.002 & $<0.001$ & 0.003 & 0.003 \\
\hline
\end{tabular}

1. One additional lag is included in the system.

2. The sample values of the maximum eigenvalue statistic for testing $\mathrm{H}_{01}: \mathrm{r}=0$ vs. $\mathrm{H}_{\mathrm{a1}}: \mathrm{r}=1$ and $\mathrm{H}_{02}: \mathrm{r}=1$ vs. $\mathrm{H}_{\mathrm{a} 2}: \mathrm{r}=2$ are 19.325 and 9.676 with estimated asymptotic $\mathrm{p}$-values of 0.001 and 0.365 respectively (MacKinnon et al., 1996). This cointegration is incorporated in an ECM prior to the noncausality tests.

3. The observed value of the test statistic is 0.779 compared to a $10 \%$ critical value of approximately 0.097 (McCabe et al., 1997): we reject the null and support noncointegration. The noncausality tests are undertaken using a DVAR(4) model.

4. General to specific testing indicated the need for five augmentation terms. The observed test statistic value of -3.302 suggests cointegration when compared with an estimated pvalue of 0.062 from MacKinnon (1994). Causality testing then proceeded using an $\operatorname{ECM}(4)$ with the error correction term formed from the residuals from the static cointegrating regression. 
Table 5 Canada : Estimated asymptotic p-values for maximum eigenvalue cointegrating rank test

\begin{tabular}{|l|c|c|c|c|c|c|c|}
\hline \multirow{2}{*}{ Case } & \multicolumn{2}{|c|}{ Bivariate } & \multicolumn{3}{c|}{ Trivariate } & \multicolumn{2}{c|}{ Conclusion } \\
\cline { 2 - 8 } & $\begin{array}{c}\mathrm{r}=0 \mathrm{vs} . \\
\mathrm{r}=1\end{array}$ & $\begin{array}{c}\mathrm{r}=1 \text { vs. } \\
\mathrm{r}=2\end{array}$ & $\begin{array}{c}\mathrm{r}=0 \mathrm{vs} . \\
\mathrm{r}=1\end{array}$ & $\begin{array}{c}\mathrm{r}=1 \mathrm{vs} . \\
\mathrm{r}=2\end{array}$ & $\begin{array}{c}\mathrm{r}=2 \text { vs. } \\
\mathrm{r}=3\end{array}$ & $\begin{array}{c}\text { Bivariate } \\
\mathrm{r} *\end{array}$ & $\begin{array}{c}\text { Trivariate } \\
\mathrm{r}^{*}\end{array}$ \\
\hline 0 & $<0.001$ & 0.995 & $<0.001$ & 0.006 & 0.999 & 1 & 2 \\
\hline $1^{*}$ & 0.001 & 0.270 & $<0.001$ & 0.044 & 0.616 & 1 & 2 \\
\hline 1 & $<0.001$ & 1.000 & $<0.001$ & 0.049 & 1.000 & 1 & 2 \\
\hline $2^{*}$ & 0.049 & 0.875 & $<0.001$ & 0.221 & 0.990 & 1 & 1 \\
\hline 2 & $<0.001$ & 0.792 & $<0.001$ & 0.117 & 0.965 & 1 & 1 \\
\hline
\end{tabular}

Note: asymptotic p-values are generated from the Fortran code provided by MacKinnon et al. (1996).

Table 6a Canada : OVER Wald Granger noncausality p-values

\begin{tabular}{|l|c|c|c|c|}
\hline \multirow{2}{*}{ Case } & \multicolumn{2}{|c|}{ BIVARIATE } & \multicolumn{2}{c|}{ TRIVARIATE } \\
\cline { 2 - 5 } & $\exp \nrightarrow \mathrm{gdp}$ & $\mathrm{gdp} \nrightarrow \exp$ & $\exp \nrightarrow \mathrm{gdp}$ & $\mathrm{gdp} \nrightarrow \exp$ \\
\hline 0 & 0.682 & 0.356 & 0.604 & 0.198 \\
\hline $1 * \& 1$ & 0.659 & 0.283 & 0.614 & 0.169 \\
\hline $2 * \& 2$ & 0.607 & 0.341 & 0.567 & 0.208 \\
\hline
\end{tabular}

Table $6 b$ Canada : JJML and TP Wald Granger noncausality p-values

\begin{tabular}{|l|l|l|l|l|l|l|}
\hline \multirow{2}{*}{ Case } & \multicolumn{3}{|c|}{ JJML } & \multicolumn{2}{c|}{ TP } \\
\cline { 2 - 7 } & \multicolumn{2}{|c|}{ BIVARIATE } & \multicolumn{2}{c|}{ TRIVARIATE } & \multicolumn{2}{c|}{ TRIVARIATE } \\
\cline { 2 - 7 } & exp $\nrightarrow$ gdp & gdp $\nrightarrow$ exp & exp $\nrightarrow$ gdp & gdp $\nrightarrow$ exp & exp $\nrightarrow$ gdp & gdp $\nrightarrow$ exp \\
\hline 0 & $<0.001$ & 0.006 & 0.657 & 0.012 & $0.657^{\mathrm{a}}$ & $0.012^{\mathrm{a}}$ \\
\hline $1 *$ & $<0.001$ & 0.001 & 0.005 & $<0.001$ & $0.005^{\mathrm{a}}$ & $<0.001^{\mathrm{a}}$ \\
\hline 1 & 0.561 & 0.002 & 0.531 & 0.001 & $0.590^{\mathrm{b}}$ & $0.001^{\mathrm{a}}$ \\
\hline $2 *$ & 0.425 & 0.002 & 0.519 & 0.240 & $0.593^{\mathrm{b}}$ & $0.255^{\mathrm{b}}$ \\
\hline 2 & 0.440 & 0.002 & 0.496 & 0.216 & $0.588^{\mathrm{b}}$ & $0.250^{\mathrm{b}}$ \\
\hline
\end{tabular}

(a) Reject $\mathrm{H}_{1}$. P-values are for testing $\mathrm{H}_{2}$.

(b) Do not reject $\mathrm{H}_{1}$. P-values are for testing $\mathrm{H}_{3}$. 
Table 7 Portugal : Estimated asymptotic p-values for maximum eigenvalue cointegrating rank test

\begin{tabular}{|l|c|c|c|}
\hline \multirow{2}{*}{ Case } & \multicolumn{2}{|c|}{ Bivariate } & Conclusion \\
\cline { 2 - 4 } & r=0 vs. $\mathrm{r}=1$ & $\mathrm{r}=1$ vs. $\mathrm{r}=2$ & $\mathrm{r}^{*}$ \\
\hline 0 & $<0.001$ & 1.000 & 1 \\
\hline $1^{*}$ & 0.001 & 0.365 & 1 \\
\hline 1 & 0.001 & 0.616 & 1 \\
\hline $2^{*}$ & 0.104 & 0.834 & 0 or 1 \\
\hline 2 & 0.001 & 1.000 & 1 \\
\hline
\end{tabular}

Note: asymptotic p-values are generated from the Fortran code provided by MacKinnon et al. (1996).

Table 8 Portugal : OVER and JJML Wald Granger noncausality p-values

\begin{tabular}{|c|c|c|c|c|c|c|c|c|c|}
\hline \multirow{3}{*}{ Noncausality } & \multicolumn{3}{|c|}{ OVER } & \multicolumn{6}{|c|}{ JJML } \\
\hline & \multirow[b]{2}{*}{$\begin{array}{c}\text { Case } \\
0\end{array}$} & \multirow[b]{2}{*}{$\begin{array}{c}\text { Cases } \\
1 \& \\
1 *\end{array}$} & \multirow[b]{2}{*}{$\begin{array}{c}\text { Cases } \\
2 \& \\
2 *\end{array}$} & \multirow[b]{2}{*}{ Case 0} & \multirow[b]{2}{*}{ Case $1^{*}$} & \multirow[b]{2}{*}{ Case 1} & \multicolumn{2}{|c|}{ Case $2 *$} & \multirow[b]{2}{*}{$\begin{array}{c}\text { Case } \\
2\end{array}$} \\
\hline & & & & & & & $\mathrm{r}^{*}=0$ & $\mathrm{r}^{*}=1$ & \\
\hline $\exp \nrightarrow$ gdp & 0.095 & 0.191 & 0.181 & 0.008 & 0.001 & 0.009 & 0.144 & 0.011 & 0.011 \\
\hline $\operatorname{gdp} \nrightarrow \rightarrow \exp$ & 0.002 & 0.002 & 0.003 & 0.002 & $<0.001$ & 0.005 & 0.001 & 0.005 & 0.003 \\
\hline
\end{tabular}


Appendix

Notes to Tables A1 \& A2

PEG Significant, positive, export-economic growth relationship.

ELG Export-led growth.

GLE Growth-led exports.

BD Bidirectional causality between the export variable \& the economic growth variable.

NC Noncausality between the export variable \& the economic growth variable.

LDC Less developed country.

NIC Newly industrialized country.

SPIN South Pacific island nation.

OLS Ordinary least squares estimation.

SEM Simultaneous equations model.

FIML Full information maximum likelihood estimation.

IV Instrumental variables estimation.

2SLS Two stage least squares estimation.

3SLS Three stage least squares estimation.

AUTOFeasible generalized least squares estimation allowing for first order serial correlation.

AR Autoregressive lag model with no lags of the dependent variable as regressors.

FB Fuller and Batesse (1974).

RC Random coefficient estimation to allow for country-specific coefficients.

GDP Gross domestic product.

GNP Gross national product.

$\Delta \quad$ First differencing operator.

$\mathrm{D}^{2} \mathrm{VAR}$ Second differenced VAR model.

BVARBayesian VAR model.

LR Likelihood ratio general to specific testing.

F $\quad F$ test of exclusion restrictions employed for the noncausality test; $F$ distribution used as finite sample approximation for the null distribution.

Wald Wald test of exclusion restrictions employed for the noncausality test; $\chi^{2}$ distribution used as finite sample approximation for the null distribution.

Akaike FPE Minimizing FPE used to examine the noncausality null hypothesis.

Rank-F See Holmes and Hutton (1990) for a discussion of the rank-F test for noncausality.

LM Lagrange multiplier test.

BIC Bayesian information criterion for lag selection.

FPE Akaike (1969) Final Prediction Error criterion for lag selection.

AIC Akaike (1973) Information criterion for lag selection.

SC Schwarz (1978) criterion for lag selection.

HQ Hannan and Quinn (1979) criterion for lag selection.

DF Dickey-Fuller unit root test. The terms in parenthesis reports the deterministic terms incorporated in the integrating regression. 
ADF Augmented Dickey-Fuller unit root test. The terms in parenthesis are the method used to choose the augmentation lag and the deterministic terms included in the integrating regression.

ZA Zivot and Andrews (1992) unit root test.

CRDW Cointegrating regression Durbin-Watson cointegration test.

EG-ADF Engle \& Granger ADF cointegration test. The terms in parenthesis are the method employed to select the augmentation lag and the deterministic terms included in the integrating regression.

PO Phillips \& Ouliaris cointegration test. The expressions in the parenthesis give the technique adopted to select the truncation lag and the deterministic components included in the integrating regression.

PP Phillips \& Perron test. The expressions in the parenthesis give the technique adopted to select the truncation lag and the deterministic components included in the relevant regression.

JJML Johansen \& Juselius maximum likelihood cointegration test. The terms in the parenthesis report the procedure used for lag selection and the deterministic components included in the relevant regression.

CCR Canonical cointegrating regression of Park (1992).

KPSS Kwiatkowski et al. ₹ unit root test. The expressions in the parenthesis give the technique adopted to select the truncation lag and the deterministic components included in the integrating regression.

ACF Autocorrelation function.

CLF Conditional linear feedback.

EH Engle and Hendry (1993).

HER Engle et al. (1993).

OVER Overfitting method proposed by Toda and Yamamoto (1995) and Dolado and Lütkepohl (1996). 
Table Al Cross-country studies of exports and growth

\begin{tabular}{|c|c|}
\hline $\begin{array}{l}\text { Authors: } \\
\text { Data: } \\
\text { Method: } \\
\text { Other variables: } \\
\text { Results: }\end{array}$ & $\begin{array}{l}\text { Maizels (1963) } \\
\text { pooled - } 7 \text { developed countries, 1899:1959 } \\
\text { rank correlation(averaged growth in manufacturing output and exports) }\end{array}$ \\
\hline $\begin{array}{l}\text { Authors: } \\
\text { Data: } \\
\text { Method: } \\
\text { Other variables: } \\
\text { Results: }\end{array}$ & $\begin{array}{l}\text { Haring \& Humphrey (1964) } \\
\text { pooled - 1950:60 } \\
\text { OLS (level of GNP on exports in current prices) }\end{array}$ \\
\hline $\begin{array}{l}\text { Authors: } \\
\text { Data: } \\
\text { Method: } \\
\text { Other variables: } \\
\text { Results: }\end{array}$ & $\begin{array}{l}\text { Emery (1967) } \\
\text { pooled - 50 countries, 1953:63 } \\
\text { OLS (averaged growth in real GNP per capita on averaged growth in exports) } \\
\text { growth in real current account earnings } \\
\text { PEG }\end{array}$ \\
\hline $\begin{array}{l}\text { Authors: } \\
\text { Data: } \\
\text { Method: } \\
\text { Other variables: } \\
\text { Results: }\end{array}$ & $\begin{array}{l}\text { Maizels (1968) } \\
\text { pooled - } 9 \text { countries, 1950:62 } \\
\text { OLS (level of GNP on level of exports) }\end{array}$ \\
\hline $\begin{array}{l}\text { Authors: } \\
\text { Data: } \\
\text { Method: } \\
\text { Other variables: } \\
\text { Results: }\end{array}$ & $\begin{array}{l}\text { Syron \& Walsh (1968) } \\
\text { pooled - } 50 \text { countries, 1953:63. } 2 \text { broad groups \& then } 3 \text { groups by } \% \text { of foodstuffs. } \\
\text { OLS (averaged growth in real GNP per capita on averaged growth in real exports) } \\
\text { PEG for broad groups. Not significant for the group with large food exports. }\end{array}$ \\
\hline $\begin{array}{l}\text { Authors: } \\
\text { Data: } \\
\text { Method: } \\
\text { Other variables: } \\
\text { Results: }\end{array}$ & $\begin{array}{l}\text { Kravis (1970) } \\
\text { pooled - } 37 \text { non-oil exporting LDCs, 1950/52:63/65 } \\
\text { rank correlation (averaged real GDP \& export changes) }\end{array}$ \\
\hline $\begin{array}{l}\text { Authors: } \\
\text { Data: } \\
\text { Method: } \\
\text { Other variables: } \\
\text { Results: }\end{array}$ & $\begin{array}{l}\text { Michalopoulos \& Jay (1973) } \\
\text { pooled - 39 LDCs, 1960:69 } \\
\text { OLS (averaged growth in real GDP on averaged growth in real exports) } \\
\text { import to GNP ratio; labor force growth; domestic \& external real investment } \\
\text { PEG }\end{array}$ \\
\hline $\begin{array}{l}\text { Authors: } \\
\text { Data: } \\
\text { Method: } \\
\text { Other variables: }\end{array}$ & $\begin{array}{l}\text { Papanek (1973) } \\
\text { pooled - } 34 \text { countries for the 1950s; } 51 \text { countries for the 1960s. Also split into groups. } \\
\text { OLS (averaged growth in real GDP on export share of GDP or averaged export share per capita) } \\
\text { averaged gross domestic savings as share of GDP; averaged net transfers received by government plus official long- } \\
\text { term borrowings as share of GDP; averaged private investment as share of GDP; averaged other foreign inflows as } \\
\text { share of GDP; averaged educational level; averaged size of the manufacturing sector. } \\
\text { insignificant PEG }\end{array}$ \\
\hline $\begin{array}{l}\text { Authors: } \\
\text { Data: } \\
\text { Method: } \\
\text { Other variables: } \\
\text { Results: }\end{array}$ & $\begin{array}{l}\text { Voivodas (1973) } \\
\text { pooled - } 22 \text { LDCs, } 1956: 67 \\
\text { OLS (real GDP growth on real export share of GDP) } \\
\text { country dummy variables } \\
\text { PEG }\end{array}$ \\
\hline $\begin{array}{l}\text { Authors: } \\
\text { Data: } \\
\text { Method: } \\
\text { Other variables: } \\
\text { Results: }\end{array}$ & $\begin{array}{l}\text { Michaely (1977) } \\
\text { pooled - } 41 \text { countries, 1950:73 \& sub-sample of } 23 \text { middle-income countries. } \\
\text { rank correlation (averaged per capita GNP growth and averaged growth of export share) }\end{array}$ \\
\hline
\end{tabular}


Table A1 Cross-country studies of exports and growth (continued)

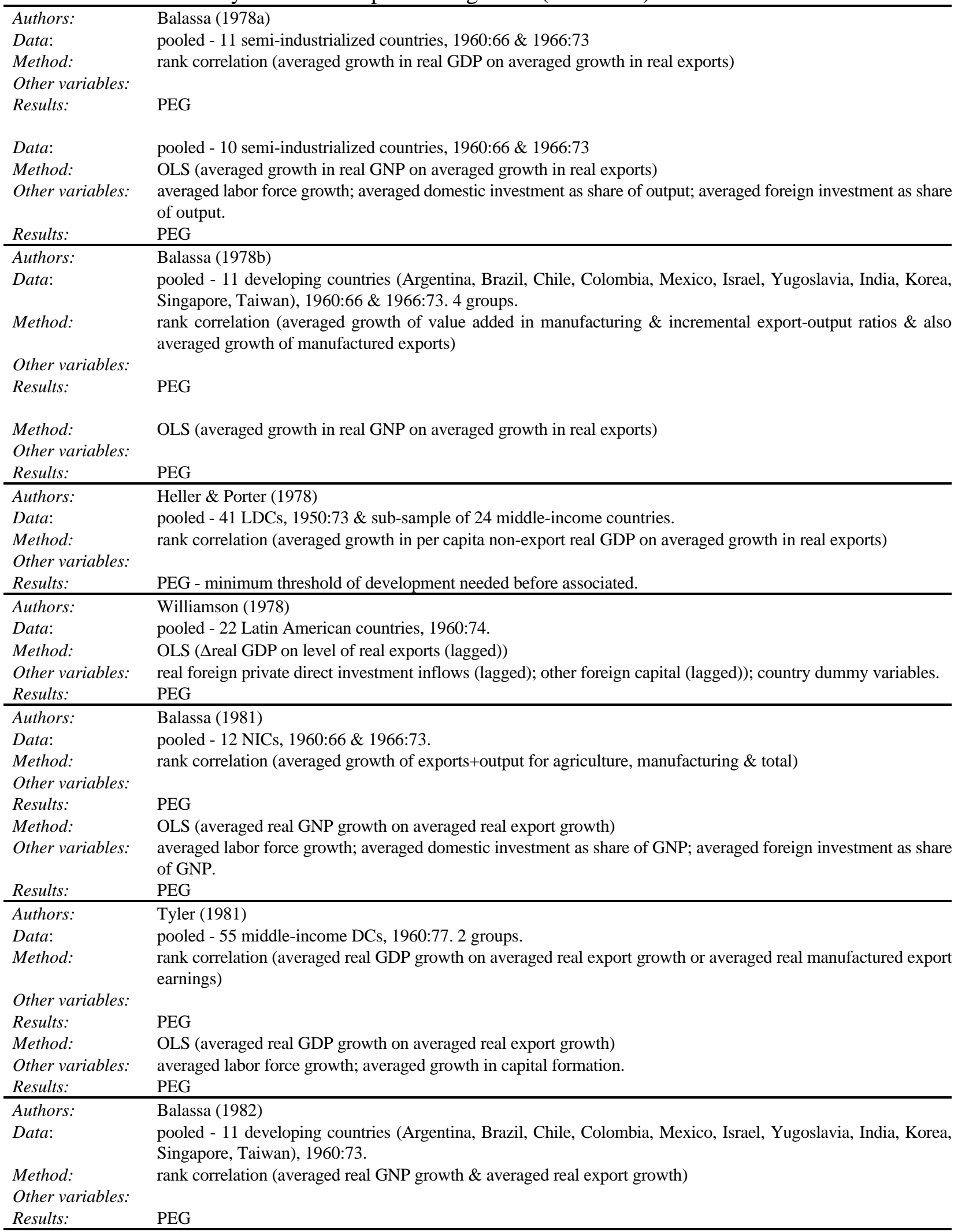


Table A1 Cross-country studies of exports and growth (continued)

\begin{tabular}{|c|c|}
\hline $\begin{array}{l}\text { Authors: } \\
\text { Data: } \\
\text { Method: } \\
\text { Other variables: } \\
\text { Results: }\end{array}$ & $\begin{array}{l}\text { Feder (1983) } \\
\text { pooled - } 19 \text { countries \& } 32 \text { countries, 1964:73. } \\
\text { OLS (averaged real GDP growth on averaged \% share of changes in exports in GDP) } \\
\text { averaged investment share of GDP; averaged population growth; foreign investment share. } \\
\text { PEG }\end{array}$ \\
\hline $\begin{array}{l}\text { Authors: } \\
\text { Data: } \\
\text { Method: } \\
\text { Other variables: } \\
\text { Results: }\end{array}$ & $\begin{array}{l}\text { Salvatore (1983) } \\
\text { panel - } 52 \text { developing countries, 1961:78. } 3 \text { groups. } \\
4 \text { equation SEM (FIML). Growth equation: growth of real per capita GDP on growth in the \% of exports to GDP. } \\
\text { in growth equation: gross fixed capital formation as \% of GDP; industrial output as \% of GDP. } \\
\text { PEG }\end{array}$ \\
\hline $\begin{array}{l}\text { Authors: } \\
\text { Data: } \\
\text { Method: } \\
\text { Other variables: } \\
\text { Results: }\end{array}$ & $\begin{array}{l}\text { Balassa (1984) } \\
\text { pooled - } 10 \text { countries. } \\
\text { OLS (averaged real GNP growth on averaged real export growth) } \\
\text { averaged labor force growth; averaged domestic investment as share of output. } \\
\text { PEG }\end{array}$ \\
\hline $\begin{array}{l}\text { Authors: } \\
\text { Data: } \\
\text { Method: } \\
\text { Other variables: } \\
\text { Results: }\end{array}$ & $\begin{array}{l}\text { Kavoussi (1984) } \\
\text { pooled - } 73 \text { developing countries, 1960:78. } \\
\text { rank correlation (averaged real GDP growth on averaged merchandise exports growth) }\end{array}$ \\
\hline $\begin{array}{l}\text { Method: } \\
\text { Other variables: } \\
\text { Results: }\end{array}$ & $\begin{array}{l}\text { OLS (averaged real GDP growth on averaged merchandise exports growth) } \\
\text { averaged labor force growth; averaged investment growth. } \\
\text { PEG }\end{array}$ \\
\hline $\begin{array}{l}\text { Authors: } \\
\text { Data: } \\
\text { Method: }\end{array}$ & $\begin{array}{l}\text { Balassa (1985) } \\
\text { pooled - } 43 \text { developing countries, 1973:79. } \\
\text { OLS (averaged real GDP growth on averaged merchandise export growth \& } 1973 \text { share of manufactured goods in } \\
\text { real total exports or averaged \% share of changes in exports in GDP) } \\
\text { averaged domestic investment share of GDP; averaged labor force growth; foreign investment share; initial year per } \\
\text { capita incomes. } \\
\text { PEG }\end{array}$ \\
\hline $\begin{array}{l}\text { Authors: } \\
\text { Data: } \\
\text { Method: } \\
\text { Other variables: }\end{array}$ & $\begin{array}{l}\text { Kormendi \& Meguire (1985) } \\
\text { pooled - } 47 \text { countries, 1950:77. } \\
\text { OLS (averaged real aggregate output growth on averaged export to output ratio) } \\
\text { per capita income; standard deviation of real output growth; averaged money supply growth; money supply shocks; } \\
\text { averaged inflation growth; averaged population growth; averaged investment to income ratio; averaged government } \\
\text { spending to output ratio. Also repeated with last variable excluded. } \\
\text { no PEG for first regression; PEG when government spending regressor excluded. }\end{array}$ \\
\hline $\begin{array}{l}\text { Authors: } \\
\text { Data: } \\
\text { Method: } \\
\text { Other variables: } \\
\text { Results: }\end{array}$ & $\begin{array}{l}\text { Jaffee (1985) } \\
\text { pooled - 80 \& } 63 \text { LDCs, 1960:77. } \\
\text { OLS (averaged log real GNP per capita on averaged exports as share of GNP) } \\
\text { initial year real GNP per capita; secondary school enrollment; population; domestic capital formation; natural resources } \\
\text { index. } \\
\text { PEG }\end{array}$ \\
\hline $\begin{array}{l}\text { Authors: } \\
\text { Data: } \\
\text { Method: } \\
\text { Other variables: } \\
\text { Results: }\end{array}$ & $\begin{array}{l}\text { Kavoussi (1985) } \\
\text { pooled - 52(51) developing countries, 1967:73 (1973:77). } \\
\text { rank correlation (averaged real GNP growth on averaged real exports growth as export orientation index) }\end{array}$ \\
\hline $\begin{array}{l}\text { Authors: } \\
\text { Data: } \\
\text { Method: } \\
\text { Other variables: } \\
\text { Results: }\end{array}$ & 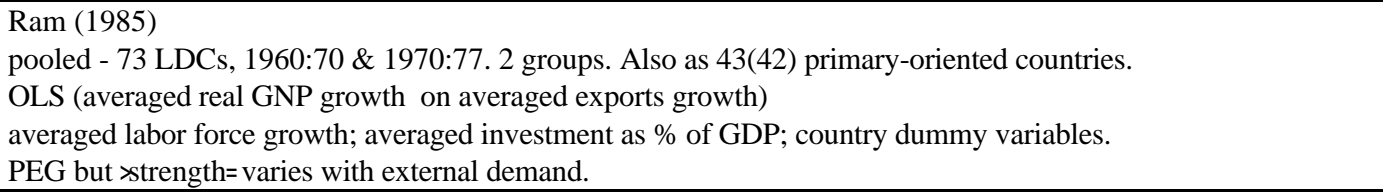 \\
\hline
\end{tabular}


Table A1 Cross-country studies of exports and growth (continued)

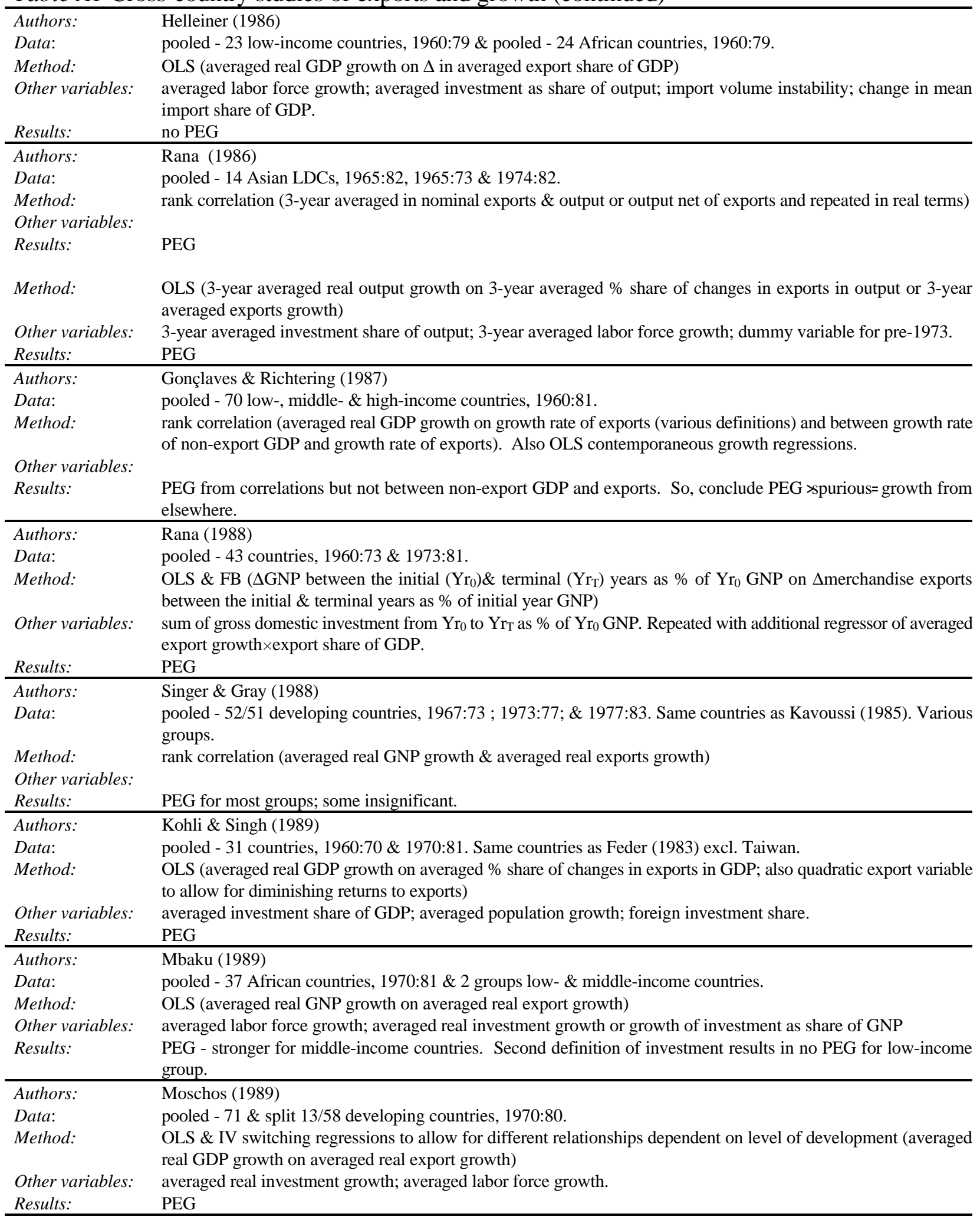


Table A1 Cross-country studies of exports and growth (continued)

\begin{tabular}{|c|c|}
\hline $\begin{array}{l}\text { Authors: } \\
\text { Data: } \\
\text { Method: } \\
\text { Other variables: } \\
\text { Results: }\end{array}$ & $\begin{array}{l}\text { Fosu (1990) } \\
\text { pooled - } 28 \text { African countries, 1960:70 \& 1970:80. } \\
\text { OLS (averaged real GDP growth on averaged real merchandise exports growth) } \\
\text { averaged investment share of GDP; averaged labor force growth. } \\
\text { PEG }\end{array}$ \\
\hline $\begin{array}{l}\text { Authors: } \\
\text { Data: } \\
\text { Method: } \\
\text { Other variables: }\end{array}$ & $\begin{array}{l}\text { Otani \& Villaneuva (1990) } \\
\text { pooled - } 55 \text { low-, middle-, \& high-income developing countries, 1970:85. } \\
\text { OLS (averaged real GDP per capita growth on averaged real exports growth) } \\
\text { averaged population growth; averaged ratio of domestic savings to GNP; averaged real interest rate on external debt; } \\
\text { averaged budgetary share of expenditure on human capital. } \\
\text { PEG }\end{array}$ \\
\hline $\begin{array}{l}\text { Authors: } \\
\text { Data: } \\
\text { Method: } \\
\text { Other variables: } \\
\text { Results: }\end{array}$ & $\begin{array}{l}\text { Sheehey (1990) } \\
\text { pooled - } 36 \text { countries, 1960:70. } \\
\text { OLS (averaged real GDP growth on averaged real exports growth or averaged \% share of changes in exports in GDP) } \\
\text { averaged investment share of GDP. } \\
\text { PEG }\end{array}$ \\
\hline $\begin{array}{l}\text { Authors: } \\
\text { Data: } \\
\text { Method: } \\
\text { Other variables: } \\
\text { Results: }\end{array}$ & $\begin{array}{l}\text { Alam (1991) } \\
\text { pooled - } 41 \text { developing countries, 1965:73 \& 1973:84. } \\
\text { OLS(averaged real GDP growth on averaged real export growth) } \\
\text { averaged investment as share of real GDP; averaged labor force growth; dummy variables for trade regimes. } \\
\text { PEG }\end{array}$ \\
\hline $\begin{array}{l}\text { Other variables: } \\
\text { Results: }\end{array}$ & $\begin{array}{l}\text { Dodaro (1991) } \\
\text { pooled - 84 LDCs, 1965:70 \& 1970:81. } \\
\text { OLS(averaged real GDP growth on averaged manufacturing exports as \% of total merchandise exports or on export } \\
\text { share defined by stage of processing) } \\
\text { country dummy =1 if over 50\% of exports are made up of fuels, minerals \& metals. } \\
\text { PEG for first; second regression also PEG but depends on degree of processing in a country } \text { export basket. }\end{array}$ \\
\hline $\begin{array}{l}\text { Authors: } \\
\text { Data: } \\
\text { Method: } \\
\text { Other variables: } \\
\text { Results: }\end{array}$ & $\begin{array}{l}\text { Esfahani (1991) } \\
\text { pooled - } 31 \text { semi-industrialized countries, 1960:73, 1973:81 \& 1980:86. } \\
\text { 2SLS(averaged GDP growth, export growth \& import growth equations) } \\
\text { relative import shortage; population; area; goods designated for domestic \& foreign usage. } \\
\text { PEG }\end{array}$ \\
\hline $\begin{array}{l}\text { Authors: } \\
\text { Data: } \\
\text { Method: } \\
\text { Other variables: } \\
\text { Results: }\end{array}$ & $\begin{array}{l}\text { Salvatore \& Hatcher (1991) } \\
\text { pooled - } 26 \text { countries, 1963:73 \& 1973:85. } 4 \text { groups depending on trade orientation. } \\
\text { OLS \& AUTO (averaged real per capita income growth on averaged real exports growth) } \\
\text { averaged gross fixed capital formation as \% of GDP; averaged real industrial production growth. } \\
\text { PEG }\end{array}$ \\
\hline $\begin{array}{l}\text { Authors: } \\
\text { Data: } \\
\text { Method: } \\
\text { Other variables: } \\
\text { Results: }\end{array}$ & $\begin{array}{l}\text { Sawhney \& DiPietro (1991) } \\
\text { pooled - } 120 \text { World Bank member countries, 1965:80. } 4 \text { groups by income. } \\
\text { OLS (averaged \% growth in real GDP on averaged \% growth in exports) } \\
\text { averaged growth in labor; averaged growth in investment. } \\
\text { PEG with importance of exports changing with the level of development. }\end{array}$ \\
\hline $\begin{array}{l}\text { Authors: } \\
\text { Data: } \\
\text { Method: }\end{array}$ & $\begin{array}{l}\text { Dollar (1992) } \\
\text { pooled - } 92 \text { countries, 1976:85. } \\
\text { OLS for relationship between price level and endowments then an index is developed (per capita GDP, average price } \\
\text { level, population density) }\end{array}$ \\
\hline $\begin{array}{l}\text { Other variables: } \\
\text { Results: }\end{array}$ & PEG \\
\hline $\begin{array}{l}\text { Authors: } \\
\text { Data: }\end{array}$ & $\begin{array}{l}\text { De Gregorio (1992) } \\
\text { pooled/panel - 12 Latin American countries (Argentina, Bolivia, Brazil, Chile, Colombia, Costa Rica, Ecuador, } \\
\text { Guatemala, Mexico, Peru, Uruguay, Venezuela), 1950:85. }\end{array}$ \\
\hline $\begin{array}{l}\text { Method: } \\
\text { Other variables: }\end{array}$ & $\begin{array}{l}\text { random effects panel (averaged rate of growth of real GDP on averaged growth of exports as share of GDP) } \\
\text { Various including: terms of trade; averaged inflation rate; variance of inflation; averaged domestic \& foreign } \\
\text { investment; literacy; political variables. }\end{array}$ \\
\hline Results: & no PEG \\
\hline
\end{tabular}


Table Al Cross-country studies of exports and growth (continued)

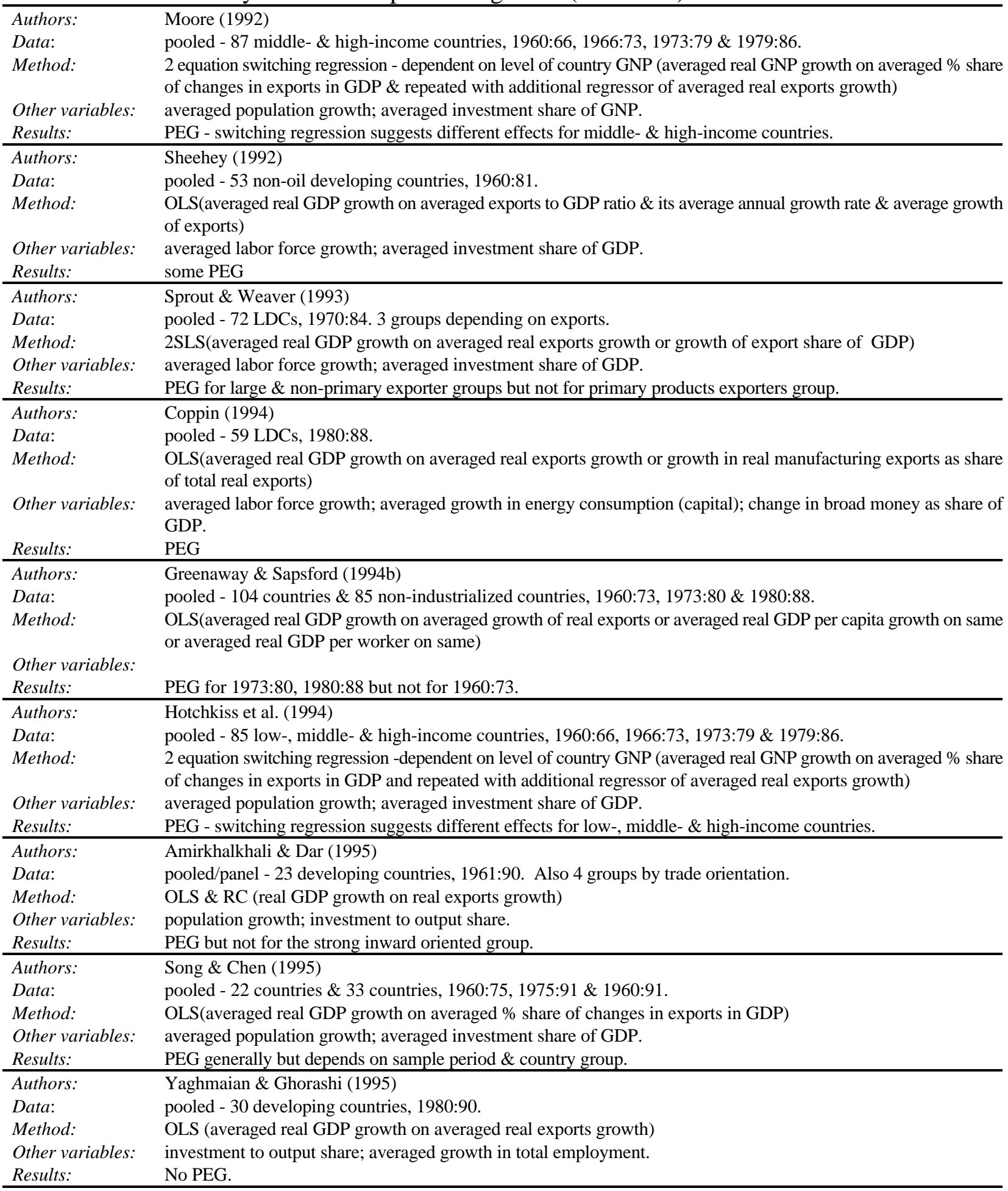


Table Al Cross-country studies of exports and growth (continued)

\begin{tabular}{|c|c|}
\hline $\begin{array}{l}\text { Authors: } \\
\text { Data: } \\
\text { Method: } \\
\text { Other variables: } \\
\text { Results: }\end{array}$ & $\begin{array}{l}\text { Burney (1996) } \\
\text { pooled - } 89 \text { countries, 1965:80 \& 95 countries, 1980:90. Also } 6 \text { groups. } \\
\text { OLS \& RC(averaged real GDP growth on averaged real exports growth) } \\
\text { averaged population growth; averaged investment growth; averaged growth in energy consumption. } \\
\text { PEG for 1980:90 but not for 1965:80. }\end{array}$ \\
\hline Authors: & Fosu (1996) \\
\hline Data: & LDCs \\
\hline Method: & $\begin{array}{l}\text { OLS (averaged real GDP growth on averaged real exports), with het-consistent ses. Repeated with averaged } \\
\text { proportion of non-fuel primary exports to total exports added as an additional regressor and replacing exports. Also } \\
\text { with non-export GDP replacing GDP. }\end{array}$ \\
\hline Other variables: & reraged gross domestic investment growth as a proportion of GDP. \\
\hline Results: & PEG \\
\hline Authors: & rk \& Prime \\
\hline Data: & oled - China 26 provinces \& $11-c o$ \\
\hline Method: & $\begin{array}{l}\text { OLS(averaged real provincial GDP growth on averaged } \% \text { share of exports in GDP or } \% \text { share of changes in exports } \\
\text { in GDP or averaged growth in real exports) }\end{array}$ \\
\hline Other va & eraged labor force growth; averaged $\%$ share of gross investment in GDP. \\
\hline Results: & exports \& \% share of changes in exports in GDP. All significant for panel model. \\
\hline Authors: & $\mathrm{cNab} \& \mathrm{Moc}$ \\
\hline Data: & \\
\hline Method: & $\begin{array}{l}\text { OLS \& 3SLS (averaged GDP growth equation \& averaged growth rate of exports weighted by the proportion of } \\
\text { exports in GDP. The GDP equation is of a Feder (1983) form while the export equation relates the dependent } \\
\text { variable to World Bank trade policy measures and GDP growth.) }\end{array}$ \\
\hline Other variables: & $\begin{array}{l}\text { averaged population growth; averaged investment to output share. Repeated also with primary and secondary } \\
\text { education ratios; initial level of real GDP per capita (proxy for technology gap). }\end{array}$ \\
\hline Results: & $\begin{array}{l}\text { PEG but conclude that high degree of correlation is likely related to bidirectional causality between the two variables } \\
\text { because of the endogeneity of the export expansion variable. }\end{array}$ \\
\hline
\end{tabular}


Table A2 Time-series studies of exports and growth

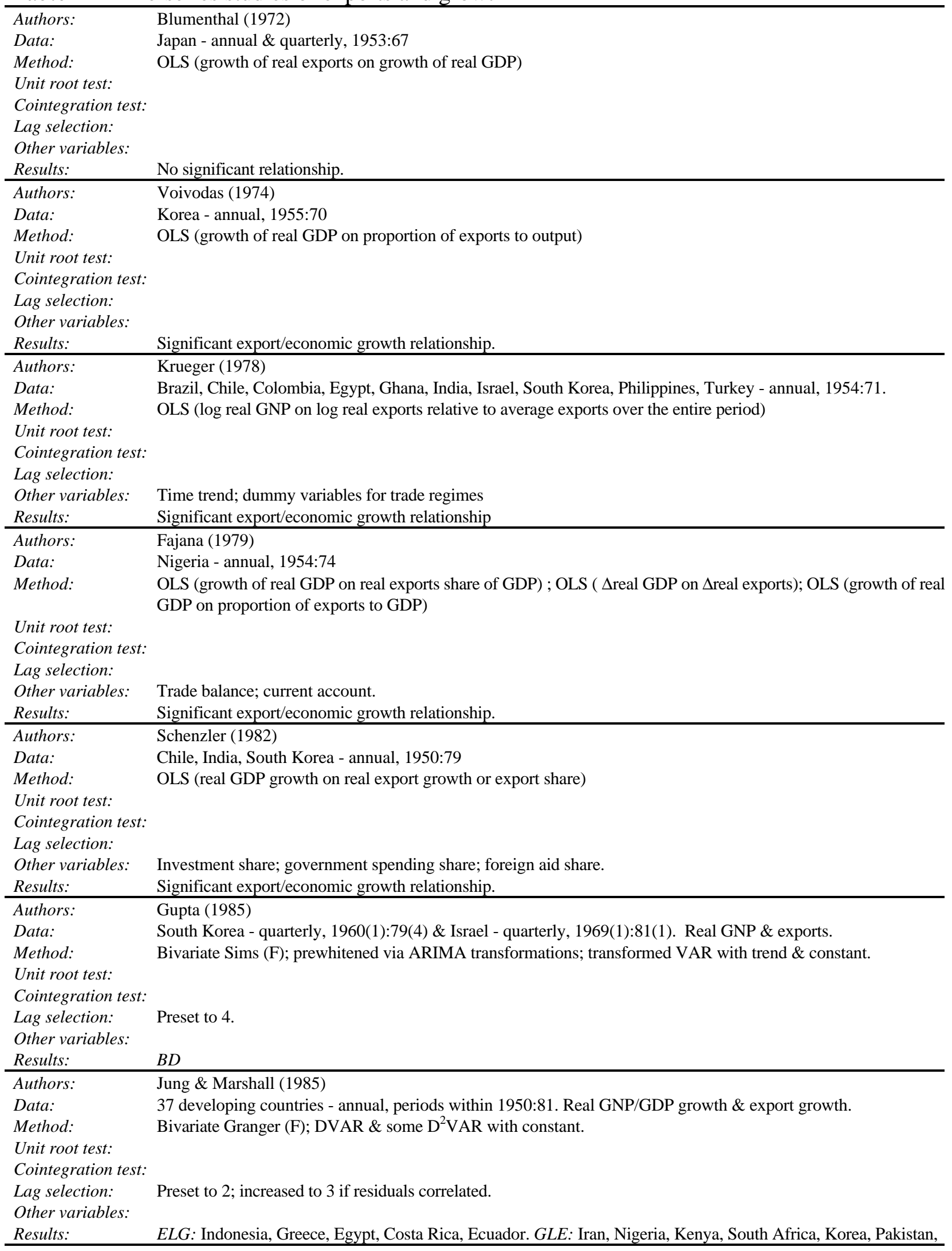


Table A2 Time-series studies of exports and growth (continued)

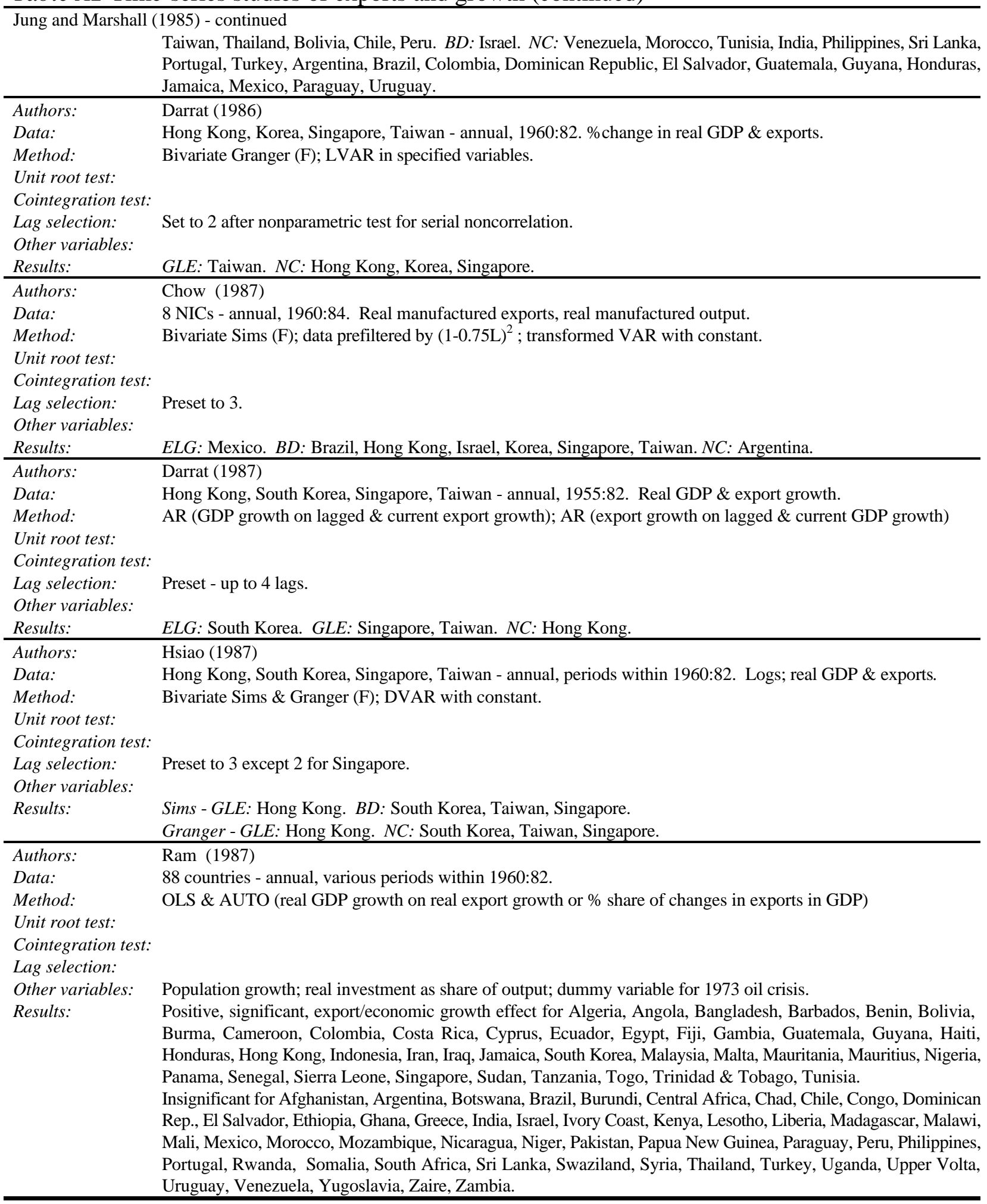


Table A2 Time-series studies of exports and growth (continued)

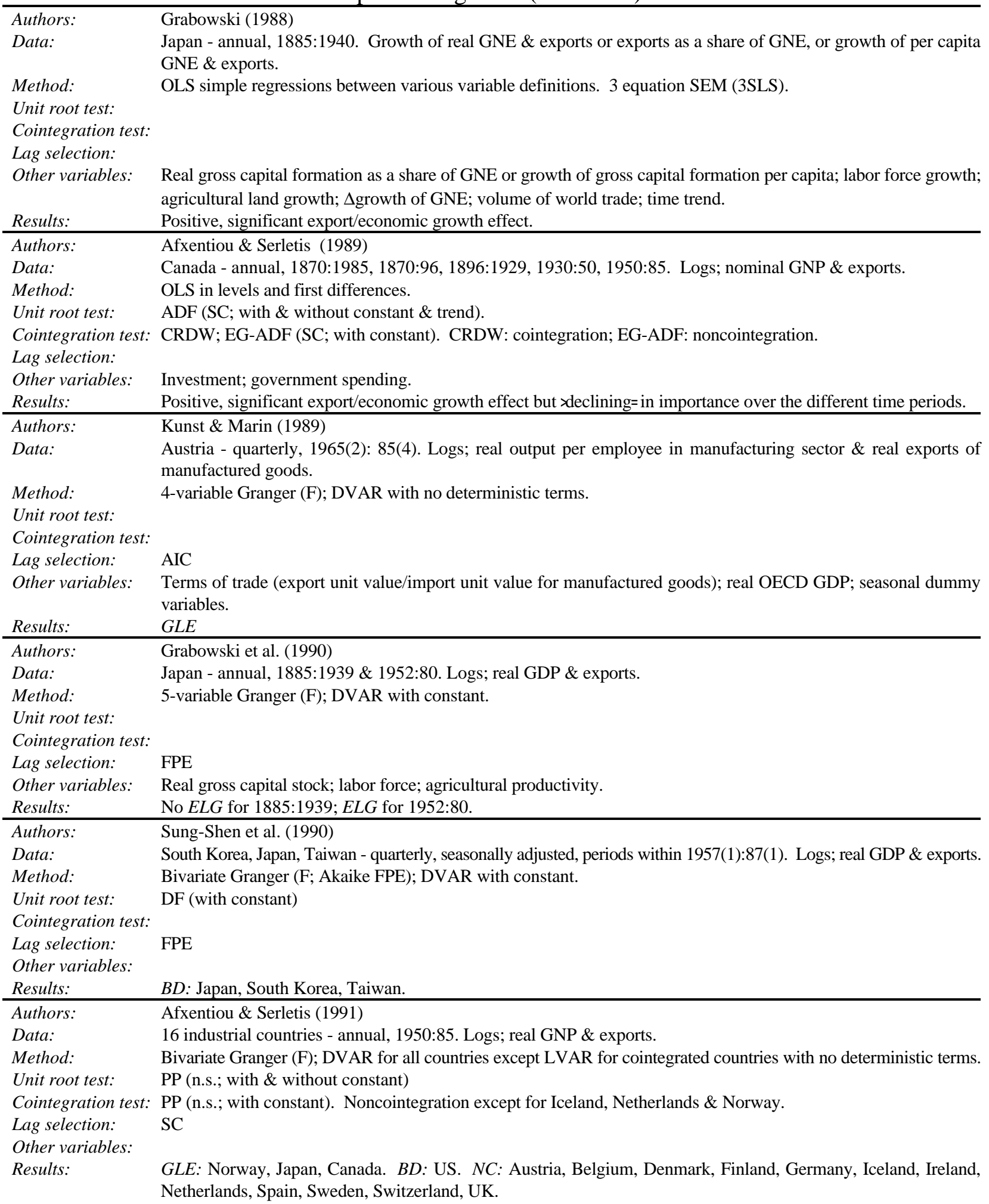


Table A2 Time-series studies of exports and growth (continued)

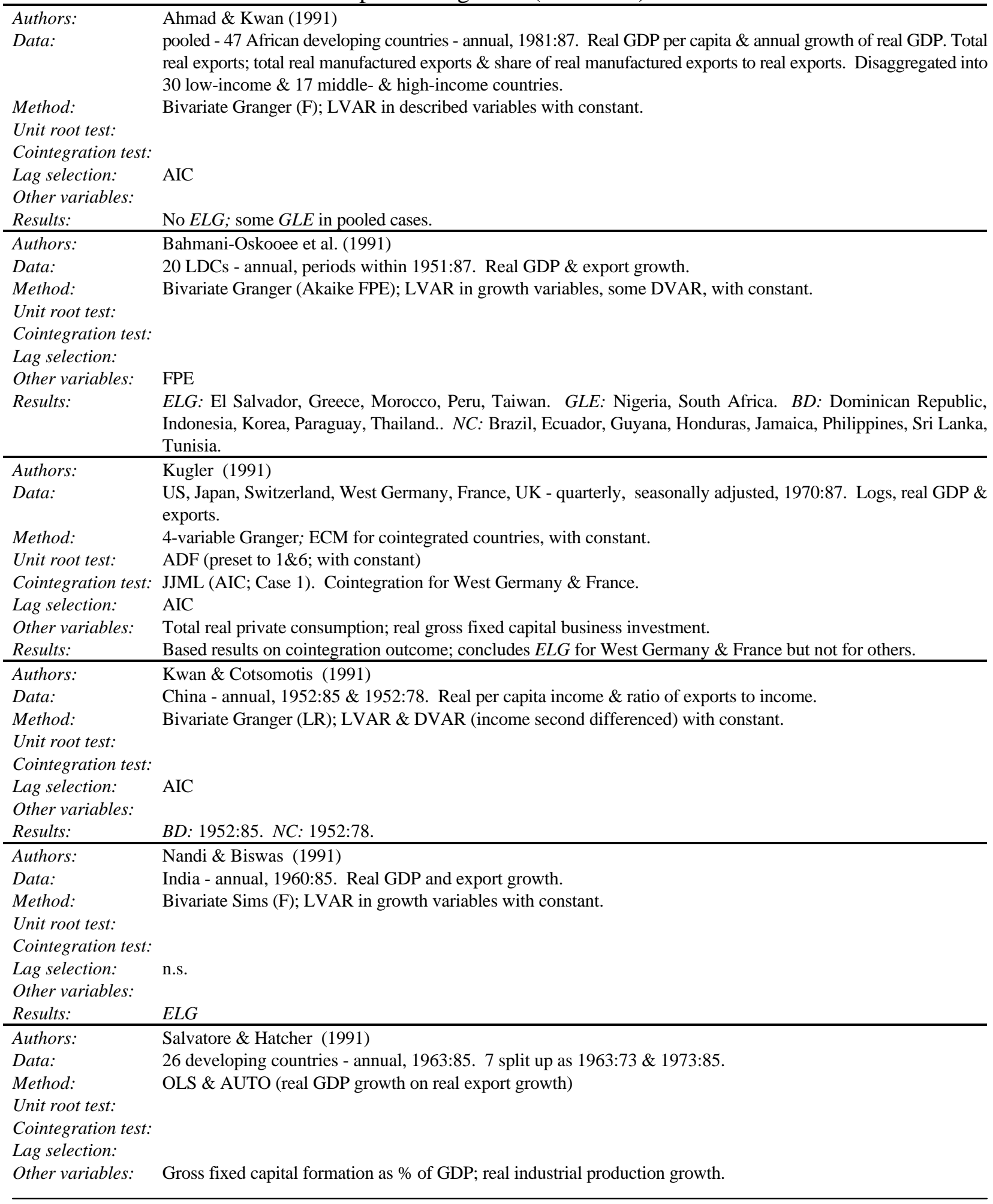


Table A2 Time-series studies of exports and growth (continued)

\begin{tabular}{|c|c|}
\hline \multicolumn{2}{|c|}{ Salvatore \& Hatcher. (1991) - continued } \\
\hline Results: & $\begin{array}{l}\text { Positive significant export coefficient for Chile, Malaysia, Tunisia, Turkey, Uruguay, Colombia, El Salvador, } \\
\text { Honduras, Ivory Coast, Senegal, Argentina, Dominican Rep., India, Nigeria, Zambia. Insignificant for South Korea, } \\
\text { Israel, Kenya, Mexico, Nicaragua, Philippines, Bagladesh, Peru, Pakistan. Significant negative for Yugoslavia, } \\
\text { Singapore. }\end{array}$ \\
\hline Authors: & Sharma et al. (1991) \\
\hline Data: & West Germany, Japan, US, UK, Italy - quarterly, 1960(1): 87(2). Logs; real GNP \& exports. \\
\hline Method: & $\begin{array}{l}\text { 4-variable Granger (LR). FEVDs ( } 4 \text { orderings; } 8 \& 20 \text { quarter horizons). Constant included. Some first differenced, } \\
\text { some first and seasonally differenced. }\end{array}$ \\
\hline \multicolumn{2}{|l|}{ Unit root test: } \\
\hline \multicolumn{2}{|l|}{ Cointegration test: } \\
\hline Lag selection: & FPE \\
\hline Other variables: & Labor; real capital formation. \\
\hline Results: & ELG: West Germany, Japan. GLE: US, UK. NC: Italy. \\
\hline Authors: & Ahmad \& Harnhirun (1992) \\
\hline Data: & 5 ASEAN countries - annual, 1967:88. Real per capita exports \& GDP. \\
\hline Method: & Bivariate Granger (LR); ECM for cointegrated countries, DVAR for noncointegrated, with constant. \\
\hline Unit root test: & $\mathrm{ADF}(\mathrm{LM} ;$ with constant $\&$ trend) \\
\hline Cointegration test: & EG-ADF (n.s.; no constant). Cointegration for Thailand; noncointegration for other countries. \\
\hline Lag selection: & FPE \\
\hline \multicolumn{2}{|l|}{ Other variables: } \\
\hline Results: & GLE: Malaysia, Philippines, Singapore, Indonesia. NC: Thailand. \\
\hline Authors: & Egwaikhide (1992) \\
\hline Data: & Nigeria - annual, 1973:88. Logs; nominal and real GDP \& oil exports. 7 component sect \\
\hline Method: & OLS (GDP on current and lagged oil exports, with constant). 3 equation SEM (2SLS). \\
\hline \multicolumn{2}{|l|}{ Unit root test: } \\
\hline \multicolumn{2}{|l|}{ Cointegration test: } \\
\hline Lag selection: & Preset to 2. \\
\hline Other variables: & Imports; export price of crude oil. \\
\hline Results: & AMarginal@ELG. \\
\hline Authors: & Giles et al. (1992) \\
\hline Data: & $\begin{array}{l}\text { New Zealand - annual, 1963:91. Logs; real exports, GDP and } 7 \text { sector decompositions (live animals, meat and edible } \\
\text { meat offal; fish, crustacea, dairy produce, and other animal produce; vegetables, fruit, prepared foodstfuffs, beverages } \\
\text { and tobacco; minerals, chemicals, plastic materials and their products; manufactures and goods classified by material } \\
\text { ( e.g., wool, paper pulp), excluding metals; metals and articles of metal; other exports) }\end{array}$ \\
\hline Method: & Bivariate Granger (LR, Wald \& Akaike FPE); ECM for cointegrated cases, DVAR for noncointegrated, with constant. \\
\hline Unit root test: & $\mathrm{ADF}$ (ACFs; with \& without constant \& trend). \\
\hline Cointegration test: & $\begin{array}{l}\text { EG-ADF (ACFs; Case } 1 * \& \text { Case } 2 * \text { ). Cointegration between GDP \& live animals etc.; between GDP \& manufactures } \\
\text { and goods classified by material. }\end{array}$ \\
\hline Lag selection: & FPE \\
\hline $\begin{array}{l}\text { Other variables: } \\
\text { Results: }\end{array}$ & $\begin{array}{l}\text { Wald \& } L R-E L G \text { : metals and articles of metals. } N C \text { for total and other categories. Akaike FPE- BD: live animals, } \\
\text { meat and edible meat offal. } E L G \text { : metals and articles of metals. GLE: manufactures and goods classified by mateial } \\
\text { (e.g., wool and paper pulp). } N C: \text { total exports and other categories. }\end{array}$ \\
\hline Authors: & Hutchison \& Singh (1992) \\
\hline Data: & 34 developing countries - annual, periods within 1950:85. Logs; real GDP, non- \\
\hline Method: & Bivariate \& trivariate Granger $(\mathrm{F})$; DVAR with no deterministic terms. \\
\hline Unit root test: & Undertaken but not specified. \\
\hline \multicolumn{2}{|l|}{ Cointegration test: } \\
\hline Lag selection: & Preset to 2. \\
\hline Other variables: & Real investment. \\
\hline Results: & $\begin{array}{l}\text { Bivariate with economic growth as non-export GDP-ELG: Argentina, Bolivia, Colombia, Costa Rica, El Salvador, } \\
\text { Guatemala, Iran, Parguay, Taiwan, Uruguay, Venezuela. GLE: Ecuador, Jamaica. NC: Brazil, Chile, Dominican } \\
\text { Rep., Egypt, Greece, Guyana, Honduras, India, Indonesia, Kenya, Korea, Mexico, Morocco, Nigeria, Pakistan, Peru, } \\
\text { Portugal, Singapore, Sri Lanka, Thailand, Tunisia. Trivariate with economic growth as non-export GDP-same as } \\
\text { bivariate except now ELG: Guyana. GLE: India, Kenya, Mexico. NC: Colombia, Costa Rica, Guatemala. }\end{array}$ \\
\hline
\end{tabular}


Table A2 Time-series studies of exports and growth (continued)

\begin{tabular}{|c|c|}
\hline Hutchison \& Singh & $\begin{array}{l}\text { (1992) - continued. } \\
\text { Bivariate with economic growth as total GDP- same as bivariate with non-export GDP except now ELG: Guyana, } \\
\text { Peru. GLE: Bolivia, Honduras, Kenya, Taiwan, Thailand. BD: Indonesia. NC: Argentina, El Salvador, Guatemala, } \\
\text { Iran, Jamaica, Uruguay, Venezuela. Trivariate with economic growth as total GDP-same as bivariate with non- } \\
\text { export GDP except now ELG: Colombia. GLE: Indonesia, Singapore, Taiwan. NC: Argentina, Bolivia, El Salvador, } \\
\text { Iran, Mexico, Thailand, Uruguay, Venezuela. }\end{array}$ \\
\hline Authors: & Marin (1992) \\
\hline Data: & $\begin{array}{l}\text { Germany, UK, US, Japan - quarterly, 1960(1):87(2). Logs; real exports of manufacturing goods \& labor productivity } \\
\text { (manufacturing output per employee). }\end{array}$ \\
\hline Method: & $\begin{array}{l}\text { 4-variable Granger }(\mathrm{F}) \text {; ECM for Germany, US \& Japan, DVAR for UK, with constant. Also tried with \& without } \\
\text { error correction term and linear time trend. }\end{array}$ \\
\hline Unit root test: & DF \& $\mathrm{ADF}$ (preset to 4; no deterministic terms). \\
\hline Cointegration test: & CRDW; DF; EG-ADF (preset to 4; no deterministic terms). Cointegration except for UK. \\
\hline Lag selection: & BIC for own lags, set to 4 for other variables. \\
\hline $\begin{array}{l}\text { Other variables: } \\
\text { Results: }\end{array}$ & $\begin{array}{l}\text { Terms of trade (export unit value/import unit value for manufacturing goods); real OECD output. } \\
\text { ELG: Germany, US, UK. BD: Japan. }\end{array}$ \\
\hline Authors: & Serletis (1992) \\
\hline Data: & Canada - annual, 1870:85; 1870:44; 1945:85. Logs; real GDP \& exports. \\
\hline Method: & Bivariate \& trivariate Granger (F); DVAR with constant. \\
\hline Unit root test: & PP $(0,12$ [2]; with constant \& trend and combinations thereof). \\
\hline Cointegration test: & PO $(0,12$ [2]; with constant). Noncointegration. \\
\hline Lag selection: & $\mathrm{SC}$ \\
\hline Other variables: & Real imports. \\
\hline Results: & ELG: 1870:44; 1870:85. NC: 1945:85. \\
\hline Authors: & Bahmani-Oskooee \& Alse (1993) \\
\hline Data: & 9 LDCs - quarterly, 1973(1):88(4). Logs; real GDP \& exports. \\
\hline Method: & Bivariate Granger (F); ECM for cointegrated countries with constant. \\
\hline Unit root test: & $\mathrm{ADF}$ (general to specific; with constant) \\
\hline Cointegration test: & $\begin{array}{l}\text { CRDW; EG-ADF (general to specific; with constant). Noncointegration for Malaysia so no further work undertaken. } \\
\text { Cointegration for other countries. }\end{array}$ \\
\hline $\begin{array}{l}\text { Lag selection: } \\
\text { Other variables: }\end{array}$ & Specific to general. \\
\hline Results: & BD: Colombia, Greece, South Korea, Pakistan, Philippines, Singapore, South Africa, Thailand. \\
\hline Authors: & Dodaro (1993) \\
\hline Data: & 87 countries - annual, 1967:86. Real GDP growth, growth of real exports of goods \& nonfactor services. \\
\hline Method: & OLS simple regression between growth variables. Bivariate Granger $(\mathrm{F})$; LVAR in growth variables with constant. \\
\hline $\begin{array}{l}\text { Unit root test: } \\
\text { Cointegration test: }\end{array}$ & \\
\hline $\begin{array}{l}\text { Lag selection: } \\
\text { Other variables: }\end{array}$ & Preset to 2. \\
\hline Results: & $\begin{array}{l}\text { OLS contemporaneous - for over half no significant relationship. Granger- ELG: Bangladesh, Ethiopia, Uganda, } \\
\text { El Salvador, Syrian Arab Republic, Malaysia, Costa Rica, Malta. GLE: Mali, Chad, Egypt, Ghana, Liberia, Zambia, } \\
\text { Guyana, Nicaragua, Chile, Yugoslavia, Singapore, Turkey, Haiti, Guatemala. BD: Indonesia, Papua New Guinea, } \\
\text { Israel. NC: Nepal, Somalia, Burundi, Burkina Faso, India, Malawi, Rwanda, Sri Lanka, Sierra Leone, Zaire, Niger, } \\
\text { Benin, Pakistan, Tanzania, Gambia, Central African Rep., Madagascar, Mauritania, Lesotho, Sudan, Togo, Kenya, } \\
\text { Senegal, Cameroon, Honduras, Zimbabwe, Thailand, Bolivia, Philippines, Yemen Arab Rep., Congo, Nigeria, } \\
\text { Botswana, Swaziland, Morocco, Peru, Mauritius, Ivory Coast, Colombia, Paraguay, Ecuador, Dominican Rep., } \\
\text { Tunisia, Jordan, Jamaica, South Korea, Algeria, Mexico, Panama, South Africa, Fiji, Brazil, Uruguay, Argentina, } \\
\text { Barbados, Portugal, Cyprus, Suriname, Trinidad \& Tobago, Venezuela, Hong Kong, Greece. }\end{array}$ \\
\hline Authors: & Ghartey (1993) \\
\hline Data: & Taiwan, US, Japan - quarterly, seasonally adjusted, periods within 1955(1):91(2). Logs; real GNP \& exports. \\
\hline Method: & $\begin{array}{l}\text { Bivariate Granger (Wald, LR) for US \& Taiwan. 4-variable Granger (Wald, LR) for Japan. FPE \& SC comparisons } \\
\text { also. Log LVAR for US (as data found stationary); D²VAR for Japan \& Taiwan, with no deterministic terms. }\end{array}$ \\
\hline Unit root test: & $\mathrm{DF}, \mathrm{ADF}$ (n.s.; with constant) \\
\hline
\end{tabular}


Table A2 Time-series studies of exports and growth (continued)

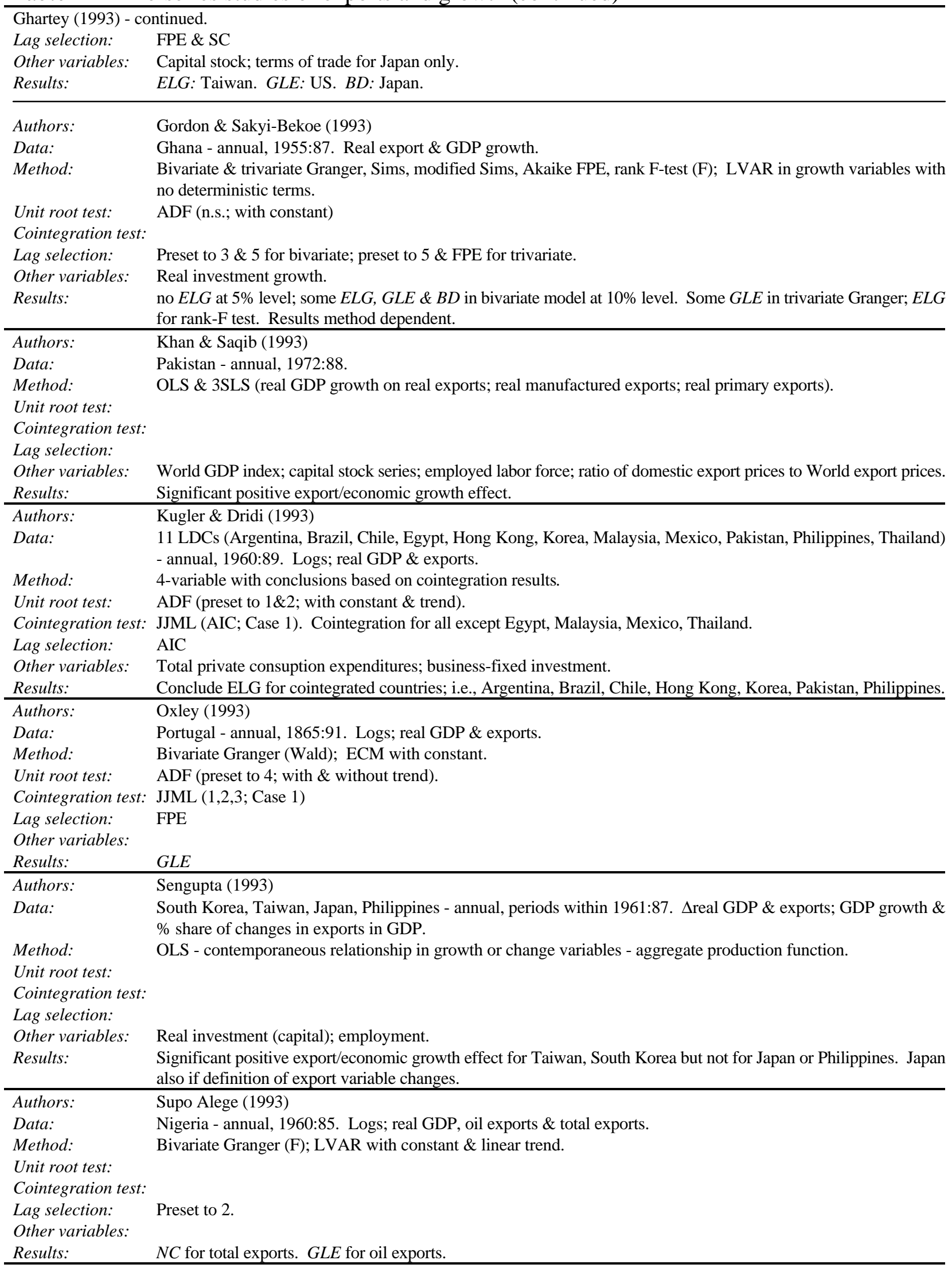


Table A2 Time-series studies of exports and growth (continued)

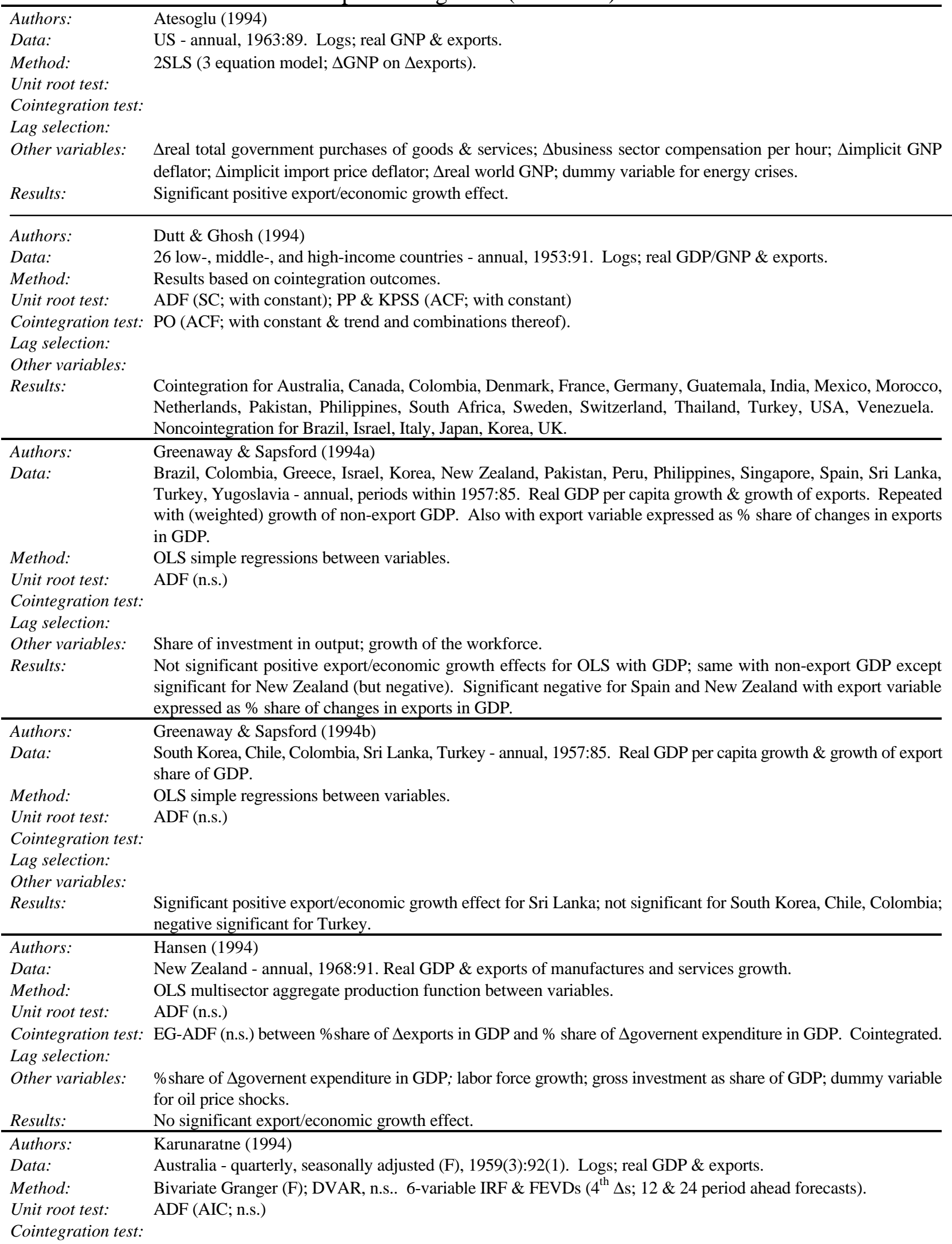


Table A2 Time-series studies of exports and growth (continued)

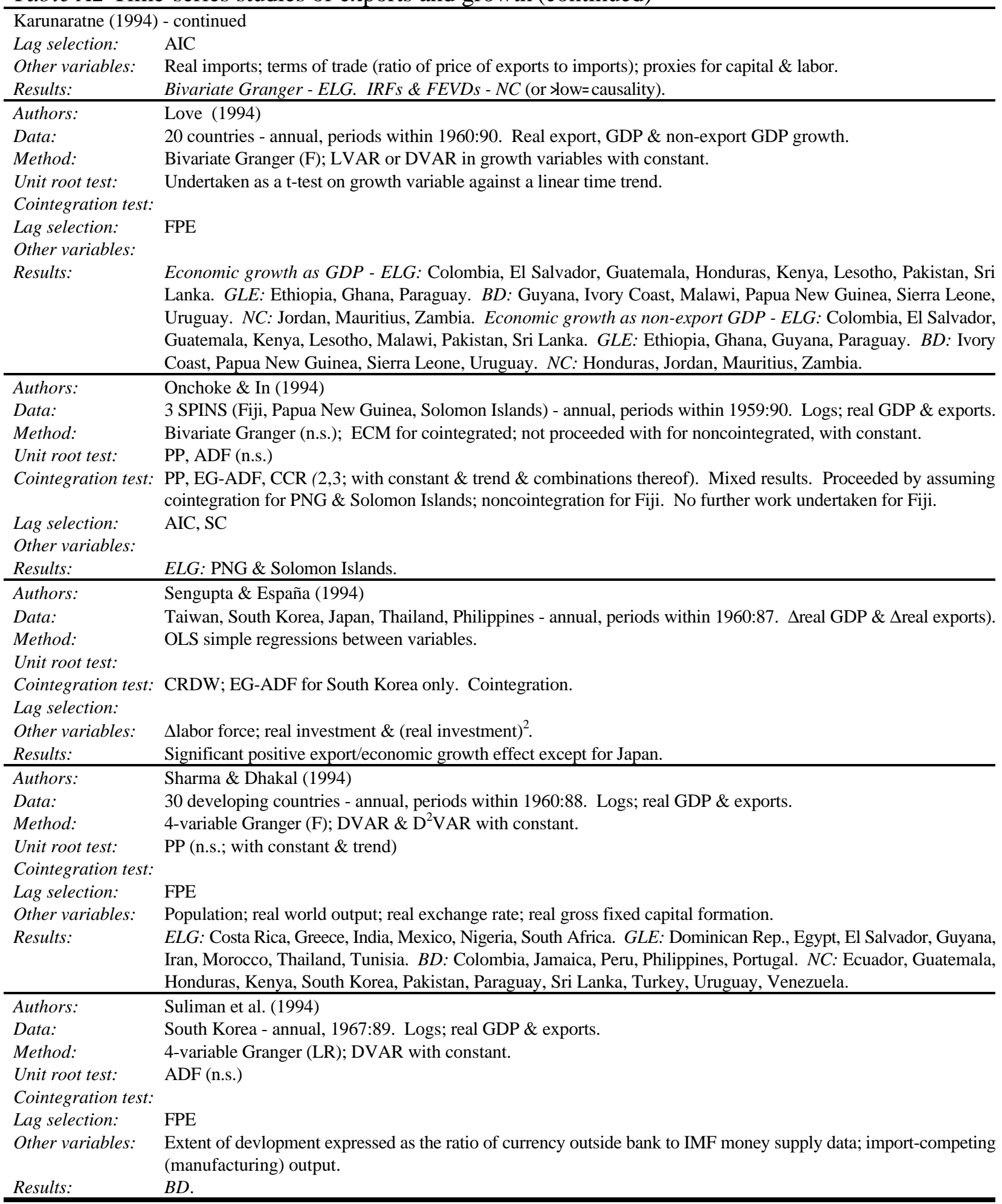


Table A2 Time-series studies of exports and growth (continued)

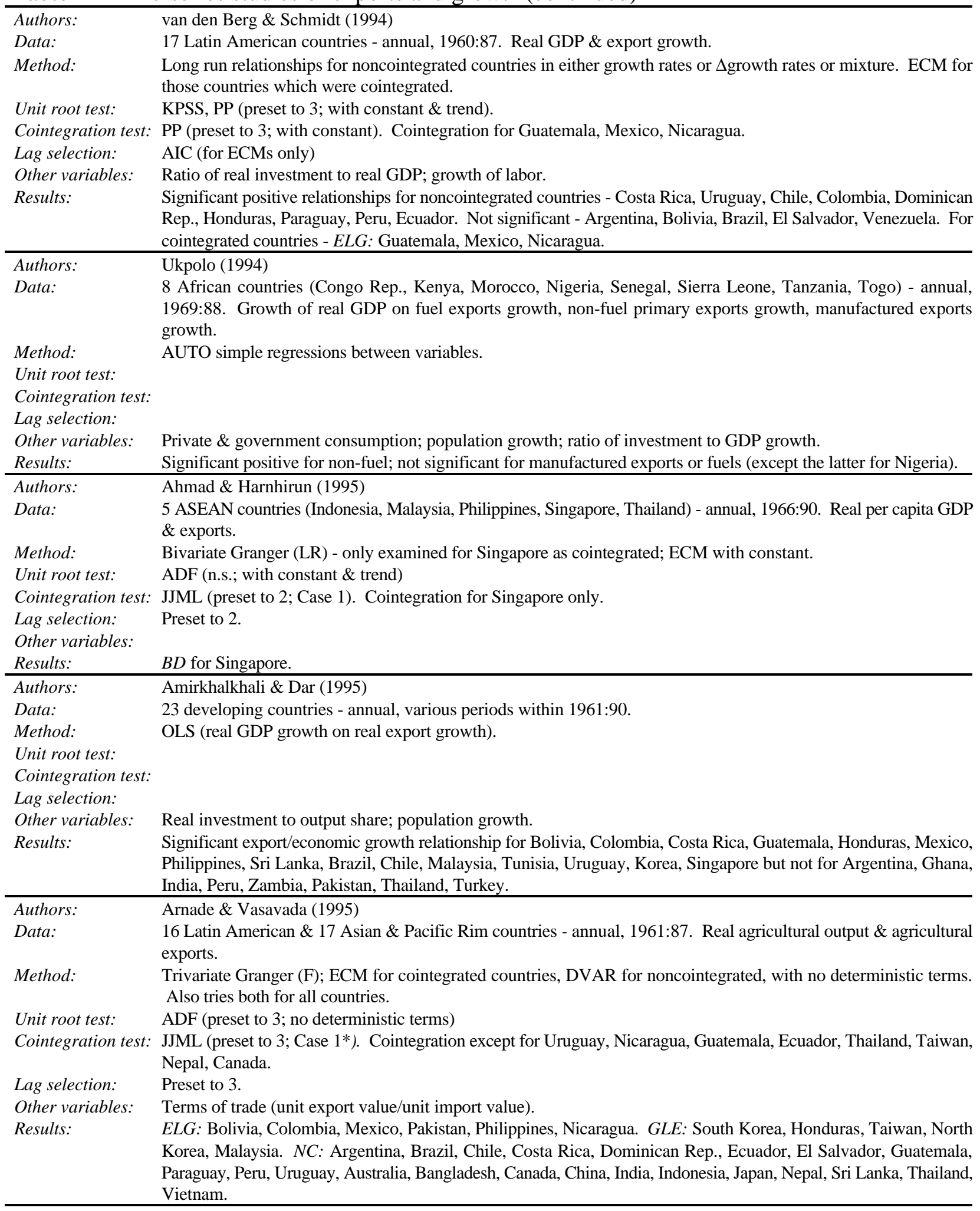


Table A2 Time-series studies of exports and growth (continued)

\begin{tabular}{|c|c|}
\hline Authors: & Bahmani-Oskooee \& Domac (1995) \\
\hline Data: & Turkey - annual, 1923:90. Logs; real GNP \& exports. \\
\hline Method: & Bivariate Granger (F); ECM with constant. \\
\hline Unit root test: & $\mathrm{ADF}$ (n.s.; with constant \& trend) \\
\hline Cointegration test: & EG-ADF (n.s.; with constant \& trend); JJML (preset to 4; Case $1 *$ ). Cointegration. \\
\hline Lag selection: & LR general to specific. \\
\hline Other variables: & \\
\hline Results: & $B D$ \\
\hline Authors: & Holman \& Graves (1995) \\
\hline Data: & South Korea - annual, 1953:90. Logs; real GNP \& exports. \\
\hline Method: & Bivariate Granger, Sims (F \& Akaike FPE); DVAR with constant. \\
\hline Unit root test: & $\mathrm{DF}$ (with constant) \\
\hline Cointegration test: & EG-ADF(n.s.; with constant) Noncointegration. \\
\hline Lag selection: & FPE \\
\hline Other variables: & \\
\hline Results: & $B D$ \\
\hline Authors: & Jin $(1995)$ \\
\hline Data: & $\begin{array}{l}\text { Hong Kong, Singapore, South Korea, Taiwan - quarterly, seasonally adjusted, 1973(1):93(2). Logs; real GDP \& } \\
\text { exports. }\end{array}$ \\
\hline Method: & 5-variable Granger; IRFs \& FEVDs - 20 quarter horizon. DVAR with constant. \\
\hline Unit root test: & $\mathrm{ADF}$ (preset to 4 ; with constant \& trend). \\
\hline Cointegration test: & EG-ADF (preset to 4; with constant \& trend). Noncointegration. \\
\hline Lag selection: & Preset to 8 except for South Korea - set to 12 to remove serial correlation. \\
\hline Other variables: & Industrial production index; world commodity price level for exports; real exchange rates. \\
\hline Results: & $B D$ \\
\hline Authors: & Jin \& Yu (1995) \\
\hline Data: & Japan, Korea, Canada \& US - quarterly, seasonally adjusted, 1960(1):87(4). Logs; real GNP/GDP \& exports. \\
\hline Method: & Bivariate Granger (F \& Akaike FPE); DVAR with constant. \\
\hline Unit root test: & \\
\hline Cointegration test: & \\
\hline Lag selection: & FPE \\
\hline Other variables: & \\
\hline Results: & GLE: Canada, US. BD: Korea, Japan. \\
\hline Authors: & Kwan \& Kwok (1995) \\
\hline Data: & China - annual, 1952:85. Logs; real national income \& exports. \\
\hline Method: & Bivariate Granger (LR); LVAR with constant. Exogeneity tests of EH \& EHR. \\
\hline Unit root test: & ZA (n.s.) \\
\hline Cointegration test: & \\
\hline Lag selection: & FPE \\
\hline Other variables: & Population; ratio of domestic investment to national income. \\
\hline Results: & $E L G$. Results also suggest instantaneous causality from exports to growth. \\
\hline Authors: & McCarville \& Nnadozie (1995) \\
\hline Data: & Mexico - annual, 1926:88. Logs; real GDP \& exports. \\
\hline Method: & Bivariate Granger (Wald \& F); DVAR with no deterministic terms. \\
\hline Unit root test: & $\mathrm{ADF}$ (SC, AIC; no constant) \\
\hline Cointegration test: & \\
\hline Lag selection: & AIC \\
\hline Other variables: & \\
\hline Results: & $E L G$ \\
\hline
\end{tabular}


Table A2 Time-series studies of exports and growth (continued)

\begin{tabular}{|c|c|}
\hline $\begin{array}{l}\text { Authors: } \\
\text { Data: } \\
\text { Method: } \\
\text { Unit root test: } \\
\text { Cointegration test: } \\
\text { Lag selection: } \\
\text { Other variables: } \\
\text { Results: }\end{array}$ & $\begin{array}{l}\text { Paul \& Chowdhury (1995) } \\
\text { Australia - annual, 1949:91. Logs; real GDP \& exports. } \\
\text { Bivariate Granger (F); DVAR with constant. } \\
\text { PP }(1,3,5,7 \text {; combinations of constant \& trend). } \\
\text { PO (1,3,5,7; with constant). Noncointegration. } \\
\text { FPE }\end{array}$ \\
\hline $\begin{array}{l}\text { Authors: } \\
\text { Data: } \\
\text { Method: } \\
\text { Unit root test: } \\
\text { Cointegration test: } \\
\text { Lag selection: } \\
\text { Other variables: } \\
\text { Results: }\end{array}$ & $\begin{array}{l}\text { Rashid (1995) } \\
\text { India - annual, 1960:89. Growth in real GDP and exports. } \\
\text { 4-equation SEM }\end{array}$ \\
\hline $\begin{array}{l}\text { Authors: } \\
\text { Data: } \\
\text { Method: } \\
\text { Unit root test: } \\
\text { Cointegration test: } \\
\text { Lag selection: } \\
\text { Other variables: } \\
\text { Results: }\end{array}$ & $\begin{array}{l}\text { Abhayaratne (1996) } \\
\text { Sri Lanka - annual, 1960:92. Logs; real GDP \& exports. } \\
\text { Trivariate Granger (Wald); DVAR with constant. } \\
\text { DF, ADF (preset to 2; with constant \& trend) } \\
\text { JJML (SC; Case 0). Noncointegration. } \\
\text { SC } \\
\text { Real imports. } \\
\text { NC }\end{array}$ \\
\hline $\begin{array}{l}\text { Authors: } \\
\text { Method: } \\
\text { Unit root test: } \\
\text { Cointegration test: } \\
\text { Lag selection: } \\
\text { Other variables: } \\
\text { Results: }\end{array}$ & $\begin{array}{l}\text { Amoateng \& Amoako-Adu (1996) } \\
35 \text { African countries, pooled into } 3 \text { groups - annual, 1971:90. Logs; real GDP \& exports. } \\
\text { Trivariate Granger (Wald); DVAR with constant. } \\
\text { Preset to } 4 \text {. } \\
\text { External debt servicing. } \\
B D\end{array}$ \\
\hline $\begin{array}{l}\text { Authors: } \\
\text { Data: }\end{array}$ & $\begin{array}{l}\text { Bodman (1996) } \\
\text { Australia and Canada - quarterly, seasonally adjusted, 1960(1):95(4). Logs; real exports of manufactured goods; real } \\
\text { total exports; manufacturing output per employee (labor productivity in the manufacturing sector); total output per } \\
\text { employee (total labor productivity). }\end{array}$ \\
\hline $\begin{array}{l}\text { Method: } \\
\text { Unit root test: } \\
\text { Cointegration test: }\end{array}$ & $\begin{array}{l}\text { Bivariate Granger (F); ECM with constant. } \\
\text { ADF \& PP (n.s.; with constant \& trend) } \\
\text { JJML (LR, SC; Case 1) between exports and labor productivity in the manufacturing sector; total exports \& total labor } \\
\text { productivity; manufactured exports \& total labor productivity. Cointegration. }\end{array}$ \\
\hline $\begin{array}{l}\text { Lag selection: } \\
\text { Other variables: } \\
\text { Results: }\end{array}$ & $\begin{array}{l}E L G \text { for both countries for all cases except } B D \text { for Canada for manufacturing exports \& manufacturing labor } \\
\text { productivity. }\end{array}$ \\
\hline $\begin{array}{l}\text { Authors: } \\
\text { Data: } \\
\text { Method: } \\
\text { Unit root test: } \\
\text { Cointegration test: } \\
\text { Lag selection: } \\
\text { Other variables: } \\
\text { Results: }\end{array}$ & $\begin{array}{l}\text { Boltho (1996) } \\
\text { Japan - annual, 1913:37; 1952:73; 1973:90. Growth of real GDP \& exports; some sectors. } \\
\text { Bivariate Granger (F); LVAR in growth variables with deterministic terms not specified. }\end{array}$ \\
\hline
\end{tabular}


Table A2 Time-series studies of exports and growth (continued)

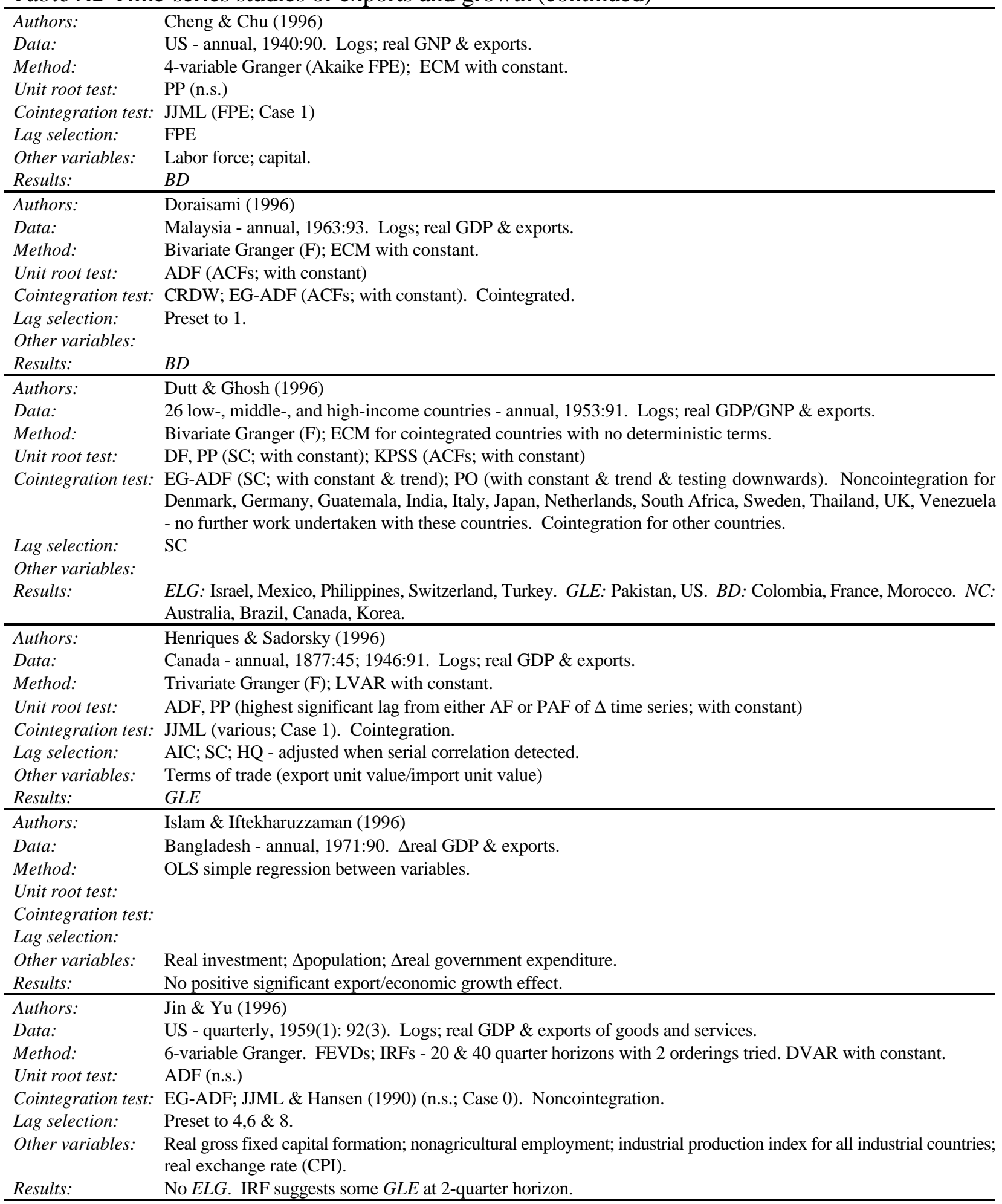


Table A2 Time-series studies of exports and growth (continued)

\begin{tabular}{|c|c|}
\hline Authors: & Karunaratne (1996) \\
\hline Data: & Australia - quarterly, seasonally adjusted, 1971(2):94(2). Real GDP per capita \& real exports of goods and services. \\
\hline Method: & 4-variable Granger (F); ECM with constant. \\
\hline Unit root test: & ADF (AIC; with constant \& trend). \\
\hline Cointegration test: & JJML (preset to 4; Case 1). Cointegration. \\
\hline Lag selection: & SC \& FPE. \\
\hline Other variables: & $\begin{array}{l}\text { Competitiveness index }=\text { terms of trade index (export price/import price deflator) } \times \text { exchange rate; OECD industrial } \\
\text { production index; regime shift dummy variable. }\end{array}$ \\
\hline Results: & $E L G$ \\
\hline Authors: & Mallick (1996) \\
\hline Data: & India - annual, 1951:92. Logs; real GNP \& exports. \\
\hline Method: & Bivariate Granger $(\mathrm{F})$; ECM with constant. \\
\hline Unit root test: & $\mathrm{ADF}$ (general to specific; with constant \& trend). \\
\hline Cointegration test: & CRDW; EG-ADF (general to specific; with constant). Cointegrated. \\
\hline Lag selection: & $1,8[2]$ \\
\hline Other variables: & \\
\hline Results: & GLE \\
\hline Authors: & Onafowora et al. (1996) \\
\hline Data: & $\begin{array}{l}12 \text { sub-Saharan African countries - annual, 1963:91. Logs; real GDP per capita \& ratio of merchandise exports to } \\
\text { real GDP. }\end{array}$ \\
\hline Method: & 4-variable Granger. FEVDS from ECMs, with constant. 12-year horizon with 2 orderings tried. \\
\hline Unit root test: & $\mathrm{ADF}$ (general to specific; with constant \& trend) \\
\hline Cointegration test: & JJML (preset to 3; Case 1). Cointegration. \\
\hline Lag selection: & Preset to 3 . \\
\hline Other variables: & Ratio of gross domestic investment to real GDP; various trade policy dummy variables. \\
\hline Results: & $\begin{array}{l}\text { ELG: Cameroon, Cote d fvoire, Ethiopia, Ghana, Madagascar, Senegal. GLE: Burundi, Kenya, Sudan, Tanzania. } \\
B D: \text { Nigeria, Zambia. }\end{array}$ \\
\hline Authors: & Piazolo (1996) \\
\hline Data: & Indonesia - annual, 1965:92. Logs. Real GDP \& exports of goods and services. \\
\hline Method: & 6-variable Granger (Wald ); ECM with constant. \\
\hline Unit root test: & ADF, PP (n.s.; with trend \& constant testing downwards). \\
\hline Cointegration test: & EG-ADF (n.s.; with constant \& trend) \& JJML (preset to 1; Case 1). Cointegration. \\
\hline Lag selection: & Preset to 1. \\
\hline Other variables: & $\begin{array}{l}\text { Real government consumption; population; real gross fixed capital formation; rate of inflation; real net foreign direct } \\
\text { investment. }\end{array}$ \\
\hline Results: & $E L G$ \\
\hline Authors: & Pomponio (1996) \\
\hline Data: & 66 OECD \& less developed countries - annual, periods within 1965:85. Nominal manufactured output \& exports. \\
\hline Method: & $\begin{array}{l}\text { Bivariate \& trivariate Granger (F); DVAR for noncointegrated countries, ECM for cointegrated, with constant. } \\
\text { Trivariate case tested as (investment+export) causes output (IELG) and (investment+output) causes exports (IGLE)). }\end{array}$ \\
\hline Unit root test: & n.s. \\
\hline Cointegration test: & n.s. \\
\hline Lag selection: & Preset to 2 , some higher if correlation detected. \\
\hline Other variables: & Investment. \\
\hline Results: & $\begin{array}{l}\text { Bivariate - ELG: Finland, Greece, Panama, Paraguay, US. GLE: Algeria, Tunisia, Burma, Thailand, Austria, } \\
\text { Denmark, Germany, Canada. BD: Trinidad \& Tobago. NC: Peru, Australia, Fiji, Indonesia, Botswana, Cameroon, } \\
\text { Ethiopia, Ghana, Kenya, Lesotho, Liberia, Mauritius, Morocco, Nigeria, Rwanda, Senegal, South Africa, Sudan, } \\
\text { Tanzania, Uganda, Zaire, Zambia, Zimbabwe, China, Japan, South Korea, Malaysia, Pakistan, Philippines, Saudi } \\
\text { Arabia, Singapore, Sri Lanka, Austria, Cyprus, France, Italy, Norway, Turkey, Argentina, Bolivia, Brazil, Chile, } \\
\text { Colombia, Costa Rica, Dominican Rep., Ecuador, El Salvador, Guyana, Honduras, Jamaica, Mexico, Nicaragua. } \\
\text { Trivariate - IELG: Cameroon, Lesotho, Nigeria, Tunisia, Japan, Saudi Arabia, Sri Lanka, Thailand, Germany, } \\
\text { Norway, Turkey, Canada, Dominican Rep., Jamaica, Paraguay, Trinidad \& Tobago, Australia. IGLE: Algeria, } \\
\text { Liberia, Senegal, Malaysia, Burma, Philippines, Cyprus, Greece, Brazil, Chile, Colombia, Costa Rica, Ecuador, El } \\
\text { Salvador, Guyana, Nicaragua, Fiji, Indonesia. BD: Botswana, Kenya, South Africa, Tunisia, South Korea, Saudi } \\
\text { Arabia, Austria, Denmark, Finland, France, Bolivia, Mexico, Peru, US. NC: Panama, Argentina, Italy, Singapore, } \\
\text { Pakistan, China, Zimbabwe, Zaire, Uganda, Tanzania, Sudan, Rwanda, Morocco, Mauritius, Ghana, Ethiopia, } \\
\text { Zambia, Honduras. }\end{array}$ \\
\hline
\end{tabular}


Table A2 Time-series studies of exports and growth (continued)

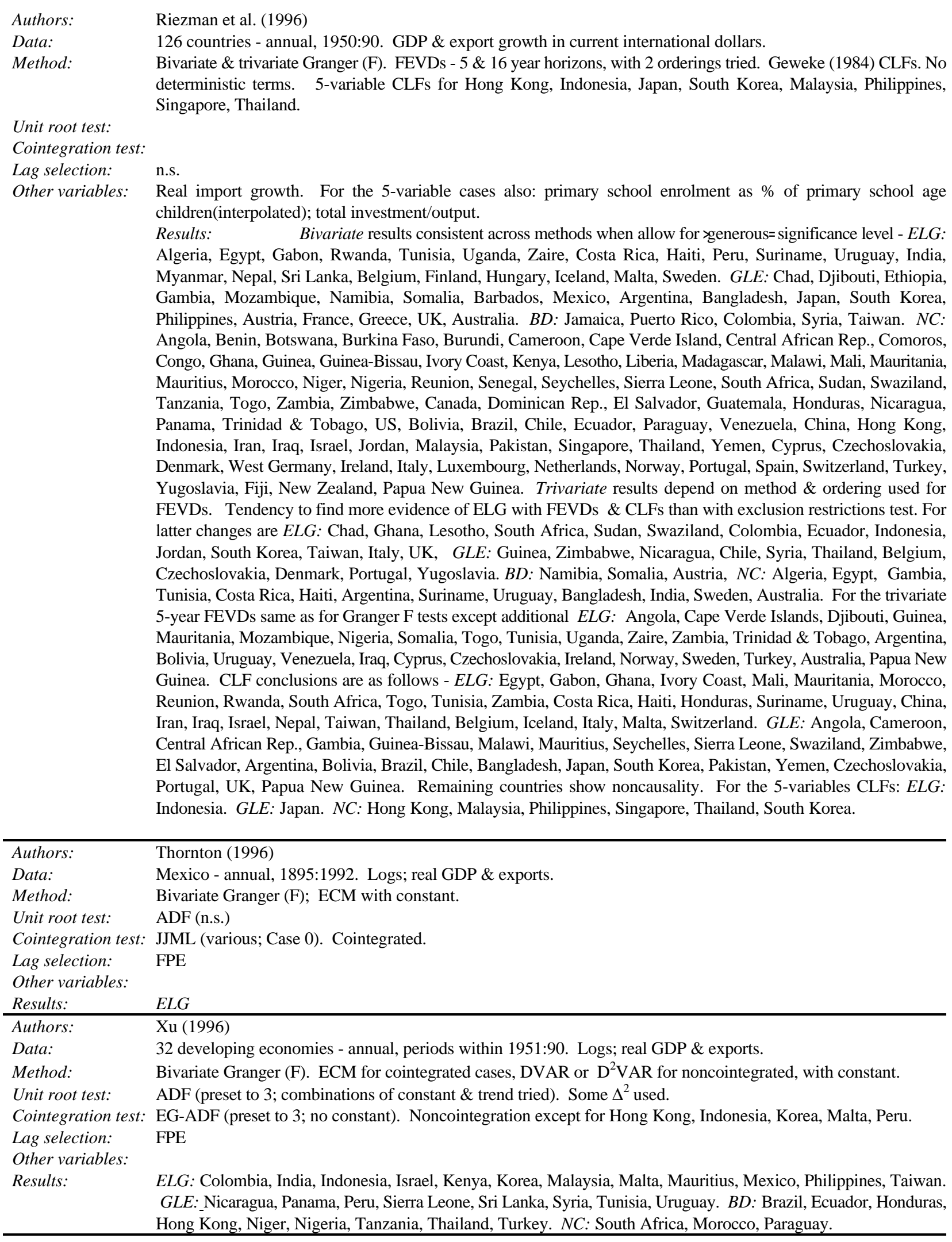


Table A2 Time-series studies of exports and growth (continued)

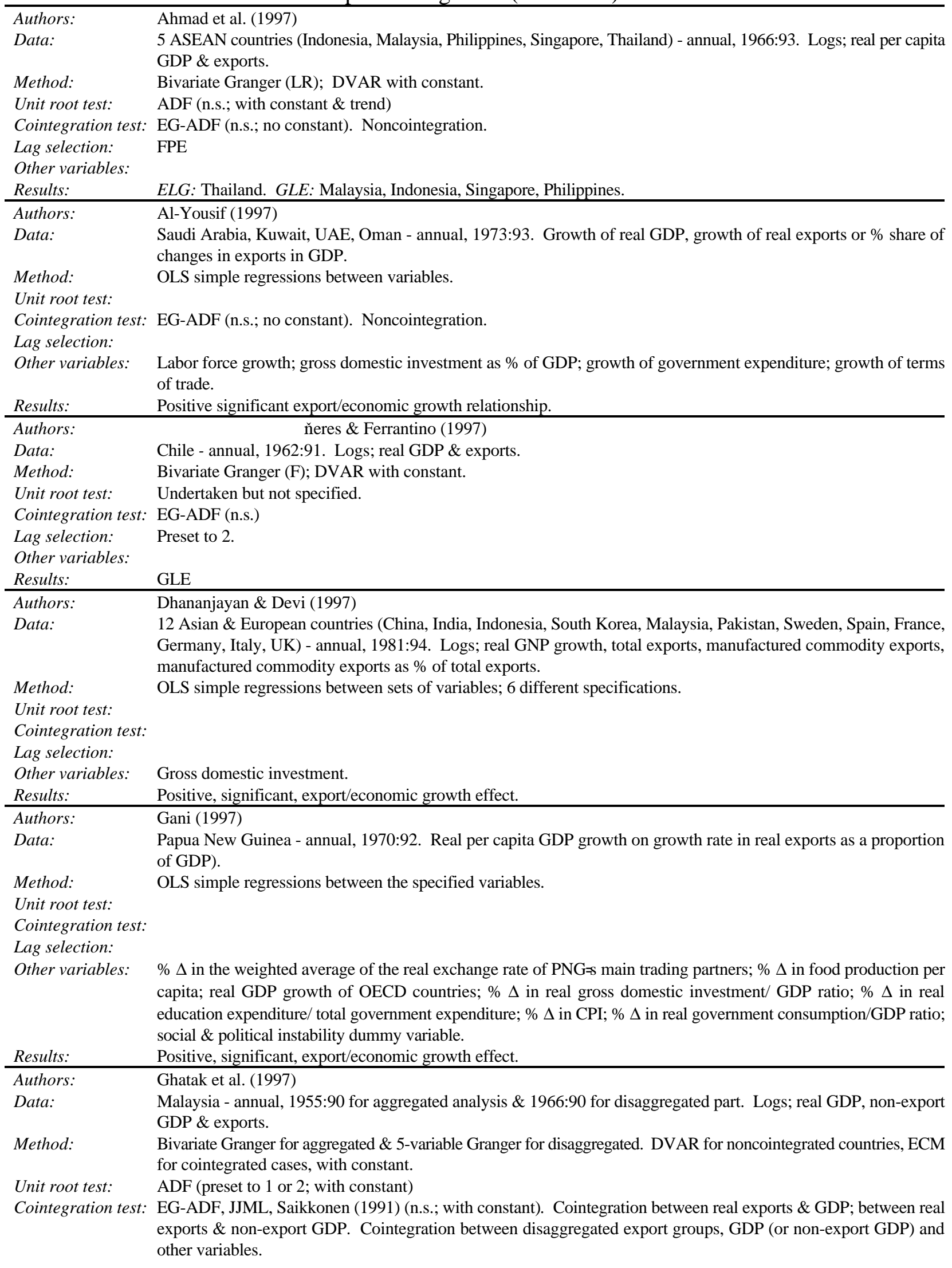


Table A2 Time-series studies of exports and growth (continued)

Ghatak et al. (1997) - continued

Lag selection: $\quad$ FPE for bivariate; preset to 1 for 5-variable case.

Other variables: $\quad$ Real gross domestic investment as \% of real GDP; enrolment ratio in primary \& secondary schools.

Results: $\quad E L G$ at aggregate level for real GDP \& real non-export GDP. ELG in disaggregated case for manufacturing exports $\&$ either GDP definition. $N C$ for fuel exports \& either GDP definition.

\begin{tabular}{|c|c|}
\hline Authors: & Greenaway et al. (1997) \\
\hline Data: & 30 post-1985 trade-liberalizing countries -annual, n.s.. $\%$ change in real GDP per capita on $\%$ change in exports. \\
\hline Method: & Panel (IV), with \& without country dummy variables. Het-consistent standard errors. \\
\hline Unit root test: & \\
\hline Cointegration test: & \\
\hline Lag selection: & \\
\hline Other variables: & Lagged $\%$ change in real GDP per capita; $\%$ change in investment; $\%$ change in the labor force. \\
\hline Results: & Positive, significant, export/economic growth effect. \\
\hline Authors: & Karunaratne (1997) \\
\hline Data: & Australia - quarterly, seasonally adjusted, 1971(1):92(4). Logs; per capita real GDP \& exports. \\
\hline Method: & 6-variable Granger - IRFS and FEVDs, $12 \& 24$ quarter horizons. ECM with constant. \\
\hline Unit root test: & ADF; PP (AIC; with constant) \\
\hline Cointegration test: & JJML (AIC; Case 1). Cointegration. \\
\hline Lag selection: & AIC \\
\hline Other variables: & $\begin{array}{l}\text { OECD production index; trade-weighted exchange rate; terms of trade index; technological innovation proxied by } \\
\text { telephone penetration as measured by main lines per capita. }\end{array}$ \\
\hline Results: & $B D$ \\
\hline Authors: & Liu et al. (1997) \\
\hline Data: & China - quarterly, 1983(3):95(1). Logs; real GNP, exports and (exports+imports). \\
\hline Method: & Bivariate Granger, Sims, Hsiao (1979) \& Geweke et al. (1983) (F); DVAR with constant. \\
\hline Unit root test: & $\mathrm{ADF}$ (AIC, SC; with constant and trend). \\
\hline Cointegration test: & EG-ADF (AIC,SC; with constant and trend). Noncointegration, \\
\hline Lag selection: & AIC, SC \\
\hline Other variables: & \\
\hline Results: & $\begin{array}{l}\text { Granger \& Hsiao - ELG. BD for (exports+imports). Sims - GLE. BD for (exports+imports). Geweke - NC. } \\
\text { (Exports+imports)LG. }\end{array}$ \\
\hline Authors: & Thornton (1997) \\
\hline Data: & Denmark, Germany, Italy, Norway, Sweden, UK - annual, periods within 1850:1913. Logs; real GDP \& exports. \\
\hline Method: & Trivariate Granger $(\mathrm{F})$. ECM for cointegrated countries, DVAR for noncointegrated, with constant. \\
\hline Unit root test: & ADF, PP (n.s.; with constant \& trend) \\
\hline Cointegration test: & JJML (AIC; Case 0). Cointegrated except for Sweden. \\
\hline Lag selection: & $\mathrm{AIC}$ \\
\hline Other variables: & Ratio of total government revenue from import duties to total imports. \\
\hline Results: & $E L G$ : Italy, Norway, Sweden. GLE: UK. BD: Denmark, Germnay. \\
\hline Authors: & Amin Gutiérrez de Piňeres \& Ferrantino (1998) \\
\hline Data: & Colombia - annual, 1962:93. Logs; real GDP \& exports. \\
\hline Method: & Bivariate \& trivariate Granger \& Sims (F); DVAR with constant. 5 equation SEM (OLS \& 3SLS). \\
\hline Unit root test: & DF (n.s.) \\
\hline Cointegration test: & EG-ADF (n.s.). Noncointegration. \\
\hline Lag selection: & Preset to 1. \\
\hline Other variables: & $\begin{array}{l}\text { Real imports for trivariate Granger/Sims. Real imports; price of coffee; price of oil; world growth rates; effective } \\
\text { export exchange rate; world interest rates; trade regime variable for SEM. }\end{array}$ \\
\hline Results: & $N C$ from Granger/Sims analysis. Significant positive export/economic growth effect in GDP equation in SEM. \\
\hline Authors: & Doyle (1998) \\
\hline Data: & Ireland - annual, 1953:93. Logs; real GDP \& exports. \\
\hline Method: & Bivariate Granger (F); ECM with constant and trend. \\
\hline Unit root test: & $\mathrm{DF}, \mathrm{ADF}$ (preset to 2; with constant) \\
\hline Cointegration test: & JJML (AIC, FPE; Case 2). Cointegration. \\
\hline Lag selection: & AIC, FPE \\
\hline Other variables: & \\
\hline Results: & $E L G$ \\
\hline
\end{tabular}


Table A2 Time-series studies of exports and growth (continued)

\begin{tabular}{|c|c|}
\hline Authors: & Ghatak (1998) \\
\hline Data: & South Korea - annual, 1950:94. Logs; real per capita GDP \& exports. \\
\hline Method: & 7-variable Granger (AIC); LVAR, BVAR, ECM, with constant. \\
\hline Unit root test: & ADF (n.s.; with constant) \\
\hline Cointegration test: & EG-ADF (n.s.; with constant and trend). Cointegration. \\
\hline Lag selection: & FPE \\
\hline Other variables: & Real per capita investment; government spending; money supply; interest rate; exchange rate. \\
\hline Results: & No $E L G$ from LVAR. $E L G$ from BVAR and ECM. \\
\hline Authors: & Islam (1998) \\
\hline Data: & $\begin{array}{l}15 \text { South East Asian countries - annual, 1967:91. Proportion of export earnings in GDP; change in share of non } \\
\text { export component in GDP; real GDP. }\end{array}$ \\
\hline Method: & Bivariate \& 5-variable Granger (F). ECM for cointegrated, DVAR for noncointegrated, with constant. \\
\hline Unit root test: & $\mathrm{ADF}(\mathrm{n} . \mathrm{s})$. \\
\hline Cointegration test: & JJML (FPE; Case 1). Noncointegration except for Bangladesh, India, Nepal, Sri Lanka, Fiji. \\
\hline Lag selection: & FPE \\
\hline Other variables: & Share of non-defence expenditures in GDP; imports as a share of GDP; total investment share of GDP. \\
\hline Results: & $\begin{array}{l}\text { Bivariate - ELG: Japan, Sri Lanka, Indonesia, Fiji, Bangladesh. BD: Nepal, Pakistan, Papua New Guinea. NC: } \\
\text { Singapore, Hong Kong, South Korea, Malaysia, Philippines, Thailand, India. Multivariate - ELG: Japan, South } \\
\text { Korea, Indonesia, Thailand, India. GLE: Malaysia. BD: Hong Kong, Singapore, Papua New Guinea, Pakistan, Sri } \\
\text { Lanka, Fiji. } N C \text { : Philippines, Nepal, Bangladesh }\end{array}$ \\
\hline Authors: & Shan \& Sun (1998a) \\
\hline Data: & Australia - quarterly, seasonally adjusted, 1978(3):96(3). Logs; real manufac \\
\hline Method: & 5-variable Granger (Wald); OVER LVAR with constant. \\
\hline Unit root test: & $\mathrm{ADF}$ (AIC \& SC; with constant \& trend) \\
\hline Cointegration test: & \\
\hline Lag selection: & $\mathrm{AIC} \& \mathrm{SC}$ \\
\hline Other variables: & Total employed persons; real imports; real gross fixed capital expenditure. \\
\hline Results: & $G L E$ \\
\hline Authors: & Shan \& Sun (1998b) \\
\hline Data: & China - monthly, seasonally adjusted, 1978(5):96(5). Logs; real industrial \\
\hline Method: & 6-variable Granger (Wald); OVER LVAR with constant. \\
\hline Unit root test: & ADF \& PP (AIC \& SC; with constant \& trend and with constant only) \\
\hline Cointegration test: & \\
\hline Lag selection: & $\mathrm{AIC} \& \mathrm{SC}$ \\
\hline $\begin{array}{l}\text { Other variables: } \\
\text { Results: }\end{array}$ & $\begin{array}{l}\text { Energy consumption; labor force; real imports and capital expenditure. } \\
B D\end{array}$ \\
\hline Authors: & Tuan \& Ng (1998) \\
\hline Data: & Hong Kong - annual, 1961:85. Logs; real GDP, re-exports, domestic export \\
\hline Method: & $\begin{array}{l}\text { Bivariate \& trivariate Granger (Wald). ECM, with constant. For trivariate case exports are decomposed as re-exports } \\
\& \text { domestic exports. }\end{array}$ \\
\hline Unit root test: & $\operatorname{ADF}(1,2,3$; with constant $)$ \\
\hline Cointegration test: & $\begin{array}{l}\text { JJML (Preset to } 2 \text { \& 3; Case 1). Specification matters; cointegration between GDP, re-exports and domestic exports, } \\
\text { so ECM. }\end{array}$ \\
\hline Lag selection: & Preset to 2 and 3. \\
\hline Other variables: & \\
\hline Results: & $E L G$ for total exports and GDP and re-exports and GDP. $N C$ for domestic exports and GDP. \\
\hline Authors: & Yamada (1998) \\
\hline Data: & $\begin{array}{l}\text { US, UK, Japan, Italy, Canada - quarterly, seasonally adjusted, 1975(1):97(2). France - quarterly, 1977(4):97(2). Logs; } \\
\text { real exports of goods \& services and labor productivity (real GDP output per employee). }\end{array}$ \\
\hline Method: & 4-variable Granger (Wald); OVER LVAR with constant. \\
\hline Unit root test: & \\
\hline Cointegration test: & \\
\hline Lag selection: & $\mathrm{HQ}$, \\
\hline Other variables: & Terms of trade (export price deflator/import price deflator); real GDP of OECD countries. \\
\hline Results: & Only examined for ELG. $H Q: E L G$ for Italy. AIC: ELG for Canada, UK. \\
\hline
\end{tabular}

